Cover: Photograph showing Chehalis River, downstream of Pe Ell, Washington, where dead spring Chinook salmon were found during 2009. Inset: Photograph of spring Chinook salmon captured for the study. Photographs by Ryan Tomka, U.S. Geological Survey. 


\title{
Behavior and Movements of Adult Spring Chinook Salmon (Oncorhynchus tshawytscha) in the Chehalis River Basin, Southwestern Washington, 2015
}

\author{
By Theresa L. Liedtke, Mara S. Zimmerman, Ryan G. Tomka, Curt Holt, and Lyle Jennings
}

Prepared in cooperation with the Washington Department of Fish and Wildlife

Open-File Report 2016-1158

U.S. Department of the Interior

U.S. Geological Survey 


\section{U.S. Department of the Interior \\ SALLY JEWELL, Secretary}

\section{U.S. Geological Survey \\ Suzette M. Kimball, Director}

U.S. Geological Survey, Reston, Virginia: 2016

For more information on the USGS-the Federal source for science about the Earth,

its natural and living resources, natural hazards, and the environment-visit

http://www.usgs.gov/ or call 1-888-ASK-USGS (1-888-275-8747).

For an overview of USGS information products, including maps, imagery, and publications, visit http://store.usgs.gov.

Any use of trade, firm, or product names is for descriptive purposes only and does not imply endorsement by the U.S. Government.

Although this information product, for the most part, is in the public domain, it also may contain copyrighted materials as noted in the text. Permission to reproduce copyrighted items must be secured from the copyright owner.

Suggested citation:

Liedtke, T.L., Zimmerman, M.S., Tomka, R.G., Holt, Curt, and Jennings, Lyle, 2016, Behavior and movements of adult spring Chinook salmon (Oncorhynchus tshawytscha) in the Chehalis River Basin, southwestern Washington, 2015: U.S. Geological Survey Open-File Report 2016-1158, 57 p., http://dx.doi.org/10.3133/ofr20161158.

ISSN 2331-1258 (online) 


\section{Contents}

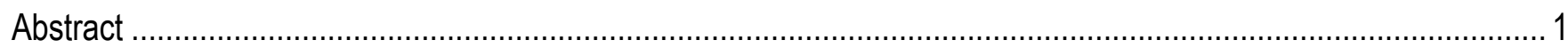

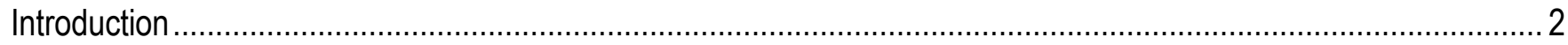

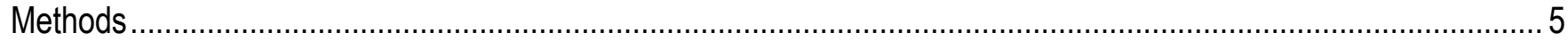

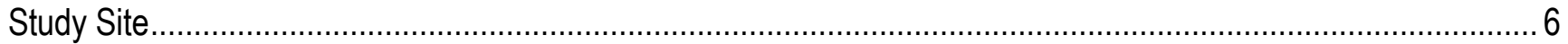

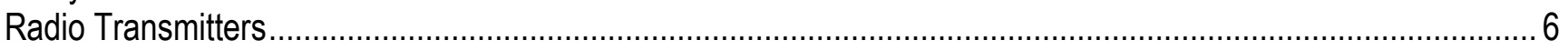

Fish Collection, Tagging, and Release

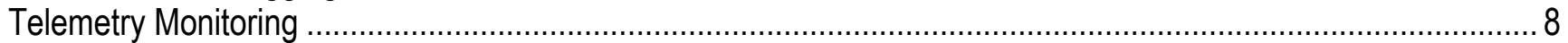

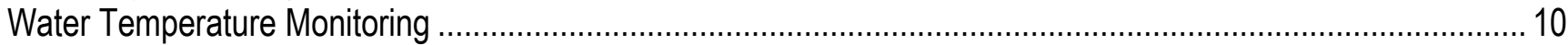

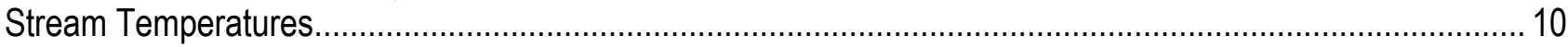

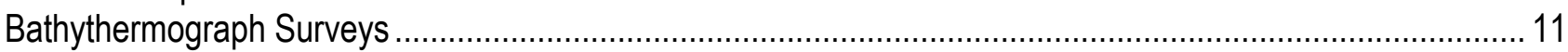

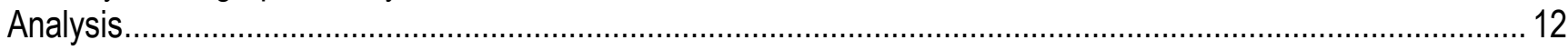

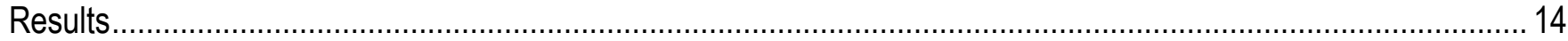



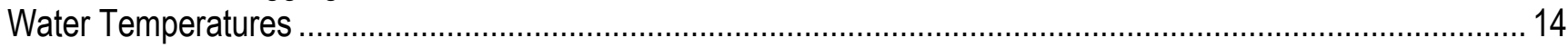

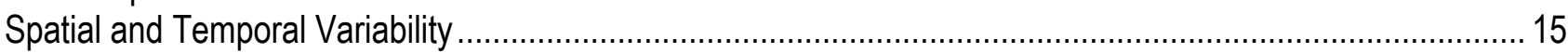

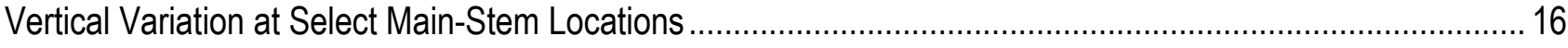

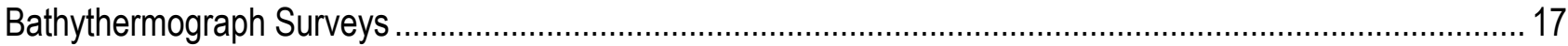

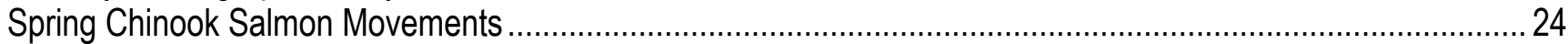

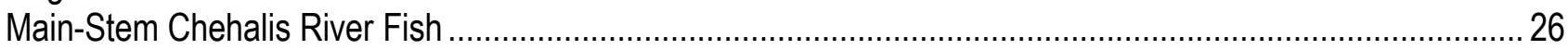

South Fork Newaukum River Fish ..................................................................................................... 31

Spring Chinook Salmon and Water Temperatures...................................................................................... 33

Questionable Performance of Tag Temperature Sensors ………........................................................... 34





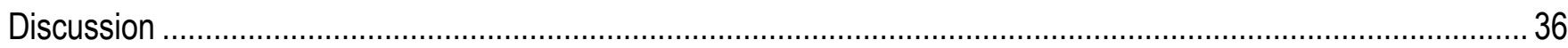

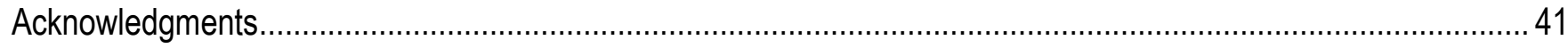

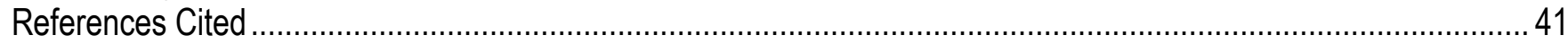

Appendix A. Controlled Tests of Transmitter Temperature Sensor Performance ................................................. 43

Appendix B. Summary of Water Temperatures in the Chehalis River Basin during Summer 2015 ........................ 52

\section{Figures}

Figure 1. Schematic showing locations of fixed-site telemetry monitoring stations and temperature loggers in the Chehalis River Basin, southwestern Washington, 2015.

Figure 2. Diagram showing transects and points used to conduct monthly bathythermograph surveys of the junction of the Chehalis River with the Skookumchuck and Newaukum Rivers, southwestern Washington, 2015.

Figure 3. Graphs showing water temperature and flows of the main-stem Chehalis River, southwestern Washington, 1960-2015.

Figure 4. Graph showing maximum stream temperature by month in the subbasins of the Chehalis River Basin, southwestern Washington, March-September 2015

Figure 5. Graphs showing July stream temperatures by elevation in the Chehalis River Basin, southwestern Washington, 2015. 
Figure 6. Graphs showing stream temperatures from "surface" and "deep" microsites at eight locations of the main-stem Chehalis River, southwestern Washington, 2015.

Figure 7. Bathythermograph profiles of the Skookumchuck River confluence with the Chehalis River, southwestern Washington, April-October 2015

Figure 8. Bathythermograph profiles of the Newaukum River confluence with the Chehalis River, southwestern Washington, May-October 2015

Figure 9. Bathythermograph profiles of the Skookumchuck and Newaukum Rivers at their confluences with the Chehalis River, southwestern Washington, June 2015

Figure 10. Graph showing timing of movements for six radio-tagged spring Chinook salmon, Chehalis River Basin, southwestern Washington, May-October 2015 29

Figure 11. Graph showing mean migration rates (in miles per day) for radio-tagged spring Chinook salmon, main-stem Chehalis River, southwestern Washington, 2015.

Figure 12. Graphs showing locations of spring Chinook salmon in North Fork and South Fork Newaukum River, southwestern Washington

\section{Tables}

Table 1. Locations of fixed-site monitoring stations in Chehalis River Basin, southwestern Washington, 2015.

Table 2. Number of spring Chinook salmon collected, radio-tagged, and released for study, Chehalis River Basin, southwestern Washington, 2015

Table 3. Differences in water temperatures between surface and deep microsites at eight locations on main-stem Chehalis River, southwestern Washington, June-August 2015

Table 4. Water temperatures and water depths from monthly bathythermograph surveys of the junction of Skookumchuck and Newaukum Rivers with main-stem Chehalis River, southwestern Washington, April-October 2015.

Table 5. Statistics for all radio-tagged spring Chinook salmon monitored during study period, Chehalis River Basin, southwestern Washington, 2015.

Table 6. Timing of first date of detection on fixed-location telemetry monitoring sites (fixed sites) for radio-tagged spring Chinook salmon captured and released in Chehalis River Basin, southwestern Washington, 2015

Table 7. Mean selected water temperatures based on transmitter temperature sensor readings for radio-tagged spring Chinook salmon detected by fixed-site telemetry monitoring stations (fixed sites) in Chehalis River, southwestern Washington, 2015 


\section{Conversion Factors}

Inch/Pound to International System of Units

\begin{tabular}{lcll}
\hline & Multiply & By & To obtain \\
\hline foot $(\mathrm{ft})$ & Length & \\
mile $(\mathrm{mi})$ & 0.3048 & meter $(\mathrm{m})$ \\
\hline & 1.609 & kilometer $(\mathrm{km})$ & \\
\hline square mile $\left(\mathrm{mi}^{2}\right)$ & Area & \\
square mile $\left(\mathrm{mi}^{2}\right)$ & 259.0 & hectare $(\mathrm{ha})$ \\
\hline & 2.590 & square kilometer $\left(\mathrm{km}^{2}\right)$ \\
\hline cubic foot per second $\left(\mathrm{ft}^{3} / \mathrm{s}\right)$ & Flow rate & \\
\hline
\end{tabular}

Fish migration rate

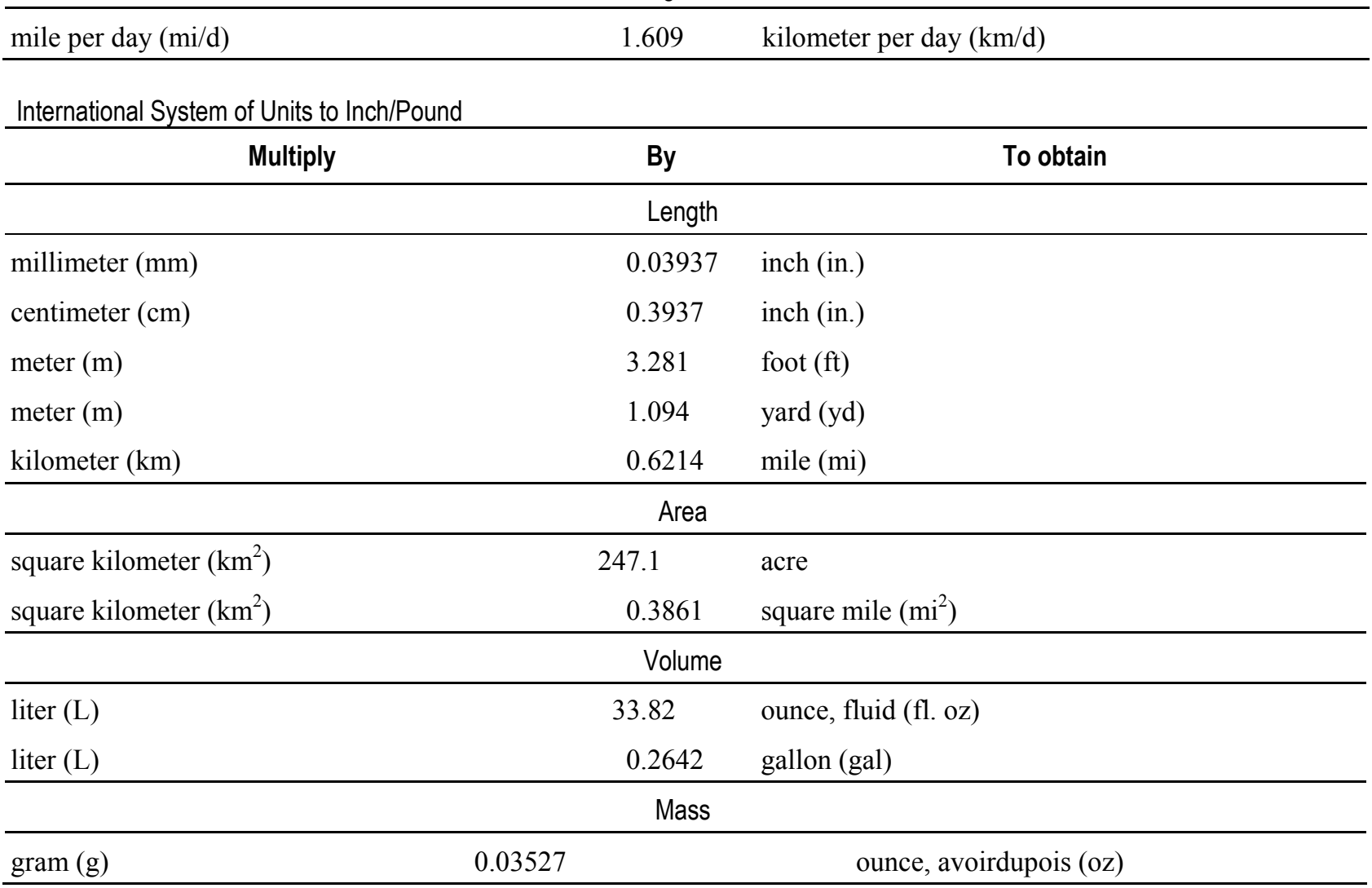

Temperature in degrees Celsius $\left({ }^{\circ} \mathrm{C}\right)$ may be converted to degrees Fahrenheit $\left({ }^{\circ} \mathrm{F}\right)$ as ${ }^{\circ} \mathrm{F}=\left(1.8 \times{ }^{\circ} \mathrm{C}\right)+32$. 


\section{Datums}

Vertical coordinate information is referenced to the North American Vertical Datum of 1988 (NAVD 88).

Horizontal coordinate information is referenced to the North American Datum of 1983 (NAD 83).

Elevation, as used in this report, refers to distance above the vertical datum.

\section{Abbreviations}

$\begin{array}{ll}\text { BT } & \text { Bathythermograph } \\ \text { GPS } & \text { Global Positioning System } \\ \text { ID } & \text { identification number } \\ \text { LCPUD } & \text { Lewis County Public Utility District } \\ \text { NIST } & \text { National Institute of Standards and Technology } \\ \text { PVC } & \text { plastic vinyl carbonate } \\ \text { RM } & \text { river mile } \\ \text { USGS } & \text { U.S. Geological. Survey } \\ \text { WDFW } & \text { Washington Department of Fish and Wildlife }\end{array}$




\title{
Behavior and Movements of Adult Spring Chinook Salmon (Oncorhynchus tshawytscha) in the Chehalis River Basin, Southwestern Washington, 2015
}

\author{
By Theresa L. Liedtke1, Mara S. Zimmerman², Ryan G. Tomka, Curt Holt², and Lyle Jennings²
}

\begin{abstract}
Recent interest in flood control and restoration strategies in the Chehalis River Basin has increased the need to understand the current status and ecology of spring Chinook salmon. Based on the extended period between freshwater entry and spawn timing, spring Chinook salmon have the longest exposure of all adult Chinook salmon life histories to the low-flow and high water temperature conditions that typically occur during summer. About 100 adult spring Chinook salmon were found dead in the Chehalis River in July and August 2009. Adult Chinook salmon are known to hold in coolwater refugia during warm summer months, but the extent to which spring Chinook salmon might use thermal refugia in the Chehalis River is unknown. The movements and temperature exposures of adult spring Chinook salmon following their return to the Chehalis River were investigated using radiotelemetry and transmitters equipped with temperature sensors, combined with water temperature monitoring throughout the basin. A total of 23 spring Chinook salmon were radio-tagged between April and early July 2015; 11 were captured and released in the main-stem Chehalis River, and 12 were captured and released in the South Fork Newaukum River. Tagged fish were monitored with a combination of fixed-site monitoring locations and regular mobile tracking, from freshwater entry through the spawning period.

Water temperature and flow conditions in the main-stem Chehalis River during 2015 were atypical compared to historical averages. Mean monthly water temperatures between March and July 2015 were higher than any decade since 1960 and mean daily flows were 30-70 percent of the flows in previous years. Overall, 96 percent of the tagged fish were detected, with a mean of $62 \mathrm{~d}$ in the detection history of tagged fish. Of the 11 fish released in the main-stem Chehalis River, six fish (55 percent) moved upstream, either shortly after release (2-7 d, 50 percent), or following a short delay (12-18 d, 50 percent). One fish released in the main-stem Chehalis River remained near the release location for $64 \mathrm{~d}$ before moving upstream.
\end{abstract}

\footnotetext{
${ }^{\top}$ U.S. Geological Survey.

${ }^{2}$ Washington Department of Fish and Wildlife.
} 
The final fates for the seven fish that moved upstream in the main-stem Chehalis River included two fish with unknown fates, two fish with a fate of pre-spawn mortality, and three fish that were assigned a fate of spawner. Four (36 percent) of the radio-tagged Chinook salmon released in the mainstem Chehalis River showed limited movement from their release sites, and were assigned fates of unknown (one fish), pre-spawn mortality (one fish), and spit/mortality ( 2 fish). The 12 spring Chinook salmon released in the South Fork Newaukum River remained in the South Fork Newaukum River throughout the study period. Five (42 percent) of these fish were actively moving through the spawning period and were assigned a fate of spawner. Seven ( 58 percent) of these fish were detected for a period following release, but their detection histories ended prior to the spawning period. The fates assigned to these seven fish included two fish with spit/mortality fates and five fish with fates of pre-spawn mortality. Tagged fish in both the Chehalis River and the South Fork Newaukum River showed limited movements during the peak water temperatures in July and August, and were not frequently detected at sites where water temperatures were greater than $21^{\circ} \mathrm{C}$. Pre-spawn mortality due to predation or harvest may be an important factor in the Chehalis River Basin as it was the assigned fate for 27 percent of the fish released in the main-stem Chehalis River and 42 percent of the fish released in the South Fork Newaukum River.

This study represents a substantial contribution to the understanding of spring Chinook salmon in the Chehalis River Basin. The water temperatures and flow conditions during the 2015 study period were not typical of the historical conditions in the basin and the numbers of tagged fish monitored was relatively low, so results should be interpreted with those cautions in mind.

\section{Introduction}

Among the species of Pacific salmon, Chinook salmon (Oncorhynchus tshawytscha) have exceptionally diverse life histories in freshwater and marine environments (Healey, 1991; Quinn, 2011). One aspect of this diversity is the timing of adult return to freshwater prior to spawning. Populations of Chinook salmon are named according to this return timing (spring-run, summer-run, fall-run, winterrun) and often coexist in the same river systems. The diversity of Chinook salmon is the focus of several ongoing research studies in the Chehalis River Basin in southwestern Washington. The Chehalis River is a low-gradient river (maximum elevation about $984 \mathrm{ft}$ or about $300 \mathrm{~m}$ ) flowing through the central coast of Washington, and is characterized by rain-dominant hydrology. Recent interest in flood control and restoration strategies in this basin has increased the need to understand the current status and ecology of aquatic species in the basin (Aquatic Species Enhancement Plan Technical Committee, 2014). Key concerns regarding Chinook salmon include understanding spatial and temporal overlap among life histories, predicting responses to flood control and restoration strategies, and anticipating climate change effects from projected changes in streamflows and temperatures. 
Based on the extended period between freshwater entry and spawn timing, spring-run (hereinafter "spring") Chinook salmon have the longest exposure of all adult Chinook salmon life histories to the low-flow conditions that typically occur during summer. Spring Chinook salmon return to freshwater 3-7 months prior to spawning (Healey, 1991) and can experience both sublethal and lethal effects if their thermal environment is too warm. For example, energetic costs after returning to freshwater include increased basal metabolic rate, migration to the spawning grounds, gamete maturation, and spawning. Adult salmon do not feed in freshwater and the energetic costs of metabolism and migration influence energetic reserves available for gamete maturation and spawning (Hearsey and Kinziger, 2015; Quinn and others, 2015). Stream temperatures generally can influence gamete development and viability of salmon and trout (Smith and others, 1983; Berman, 1990). Berman and Quinn (1991) calculated that a $2-5^{\circ} \mathrm{C}$ decrease in temperature would be associated with a 25 -percent reduction in basal metabolic rate of spring Chinook salmon in the Yakima River. Such a reduction in metabolic rate conserves energy for gamete development and spawning. Stream temperatures exceeding $21{ }^{\circ} \mathrm{C}$ are observed to halt the upstream migration of adult salmon (Richter and Kolmes, 2005), including spring Chinook salmon in the Columbia River Basin (Alabaster, 1988; Dauble and Mueller, 1993). Lethal temperatures for adult spring Chinook salmon are between 24 and $26{ }^{\circ} \mathrm{C}$ (Sullivan and others, 2000; Richter and Kolmes, 2005), and may depend on a number of factors including previous acclimation temperatures and duration of exposure.

Thermal heterogeneity of rivers during summer is a critical aspect of the ecology of spring Chinook salmon. Within the freshwater environment, adult Chinook salmon are known to hold in coolwater refugia to reduce metabolic costs during warm summer months (Berman and Quinn, 1991; Torgersen and others, 1999; Goniea and others, 2006). The extent to which spring Chinook salmon might use thermal refugia in the Chehalis River is currently (2016) unknown.

Thermal heterogeneity in rivers may occur at large spatial scales because of elevational gradients (Rahel and Hubert, 1991; Rieman and McIntyre, 1995) or more local scales because of tributary inputs, groundwater seeps, shading, or vertical stratification (Ebersole and others, 2003; Caissie, 2006; Tiffan and others, 2009; Dugdale and others, 2015). In the Chehalis River, the availability of suitable water temperature and habitat for adult spring Chinook salmon is a particular conservation concern. Adult spring Chinook salmon are exposed to multiple environmental stressors during their summer holding period including low flows, warm temperatures, and low oxygen levels. These stressors are a natural product of the rain-dominant hydrology but also have been exacerbated by land use practices, including water withdrawals and removal of riparian vegetation (Smith and Wenger, 2001). Temperature and oxygen levels influence energy reserves and survival. For example, fish kills of adult Chinook salmon in the Chehalis River were observed in late July and early August 2009 (Mike Kohn, Lewis County Public Utility District, written commun., 2009). During this event, about 100 adult spring Chinook salmon were found dead at several locations in the river, including river mile 73 and 104 of the main-stem Chehalis River and the lower Newaukum River downstream of the confluence of the north and south forks. Water temperatures obtained from the fish kill locations by LCPUD on August 3 and 4, 2009 (several days after the fish kill event ) exceeded $21.0^{\circ} \mathrm{C}$; however, dissolved oxygen conditions were not documented (Mike Kohn, Lewis County Public Utility District, written commun., 2009). 
The behavior of spring Chinook salmon in the Chehalis River appears to be distinctive compared to the behavior of populations in snowmelt rivers. In snowmelt rivers, adult spring Chinook salmon enter the rivers during spring runoff, migrate and spawn at farther distances from the ocean than other life histories, and the juveniles rear longer in the river than other life histories. In the Chehalis River, there is no spring snowmelt runoff and adults enter freshwater as the hydrograph is descending towards summer low flows between February and June. As a further contrast, spring and fall Chinook salmon in the Chehalis River migrate similar distances to the spawning grounds and are separated only by the timing of the spawning event. In some areas, fall Chinook salmon spawn at farther distances from the ocean than the spring Chinook salmon, showing an opposite pattern from the "typical" spatial separation observed for these life histories. Further contrast among spring Chinook salmon populations is observed in the juvenile life history. In the Chehalis River, scale ages of spring Chinook salmon that successfully return to spawn indicate that most of the fish left freshwater as subyearlings (L. Campbell, Fish Aging Laboratory, Washington Department of Fish and Wildlife, oral commun., 2016). Thus, better understanding of spring Chinook salmon in the Chehalis River may expand our general understanding of factors contributing to Chinook salmon diversity. Specifically, more information is needed on the behavior and associated temperature exposures of adult spring Chinook salmon during their freshwater residency in the Chehalis River. This understanding also should help to inform the types of future habitat protections and fish management actions that will benefit this life history and help to preserve the long-term diversity of Chinook salmon in the basin.

A study of spring Chinook salmon movements in the Chehalis River during spring and summer 2014 provided some valuable insights into fish behavior in this basin and was used to guide, some aspects of the current study. In 2014, the U.S. Geological Survey (USGS) and Washington Department of Fish and Wildlife (WDFW) conducted a pilot study of adult spring Chinook salmon movements in the system using radiotelemetry. The pilot study transmitters were equipped with a temperature sensor and fish were monitored with an array of telemetry stations. Although the pilot study findings have not been formally summarized or reported, the general findings were useful in planning and executing the current study (U.S. Geological Survey, unpub. data, 2014). From May to June 2014, 12 spring Chinook salmon were tagged and released in the Chehalis River. Study fish were regularly detected at the mouths of the Skookumchuck and Newaukum Rivers (fig. 1), and showed limited movements from late July to early September, during the peak water temperatures. Final locations for fish at the end of the study included three fish in the Skookumchuck River (including one fish 22 river miles upstream of the mouth), three fish in the Newaukum River (including one fish 28 river miles upstream of the mouth), two fish with unknown fates, three fish assumed to have died or to have regurgitated their transmitters, and one fish that was recaptured during efforts to collect fish for tagging (U.S. Geological Survey, unpub. data, 2014). Although stream water-temperature-monitoring efforts were limited in 2014, some examples of behavioral thermoregulation were observed where the transmitter temperature sensor showed a selected water temperature lower than the observed ambient water temperature (U.S. Geological Survey, unpub. data, 2014). 
The movements and temperature exposures of adult spring Chinook salmon following their return to the Chehalis River are investigated in this study. We used radio transmitters equipped with a temperature sensor that were implanted in adult spring Chinook salmon to allow us to monitor movement patterns and water-temperature exposures and selections during their freshwater residency. This technique was previously used by Berman and Quinn (1991) to evaluate similar factors for spring Chinook salmon in the Yakima River, Washington. Concurrent with the fish monitoring efforts, we used an array of temperature loggers and focused bathythermograph profiles to describe water temperatures throughout the basin during the study period.

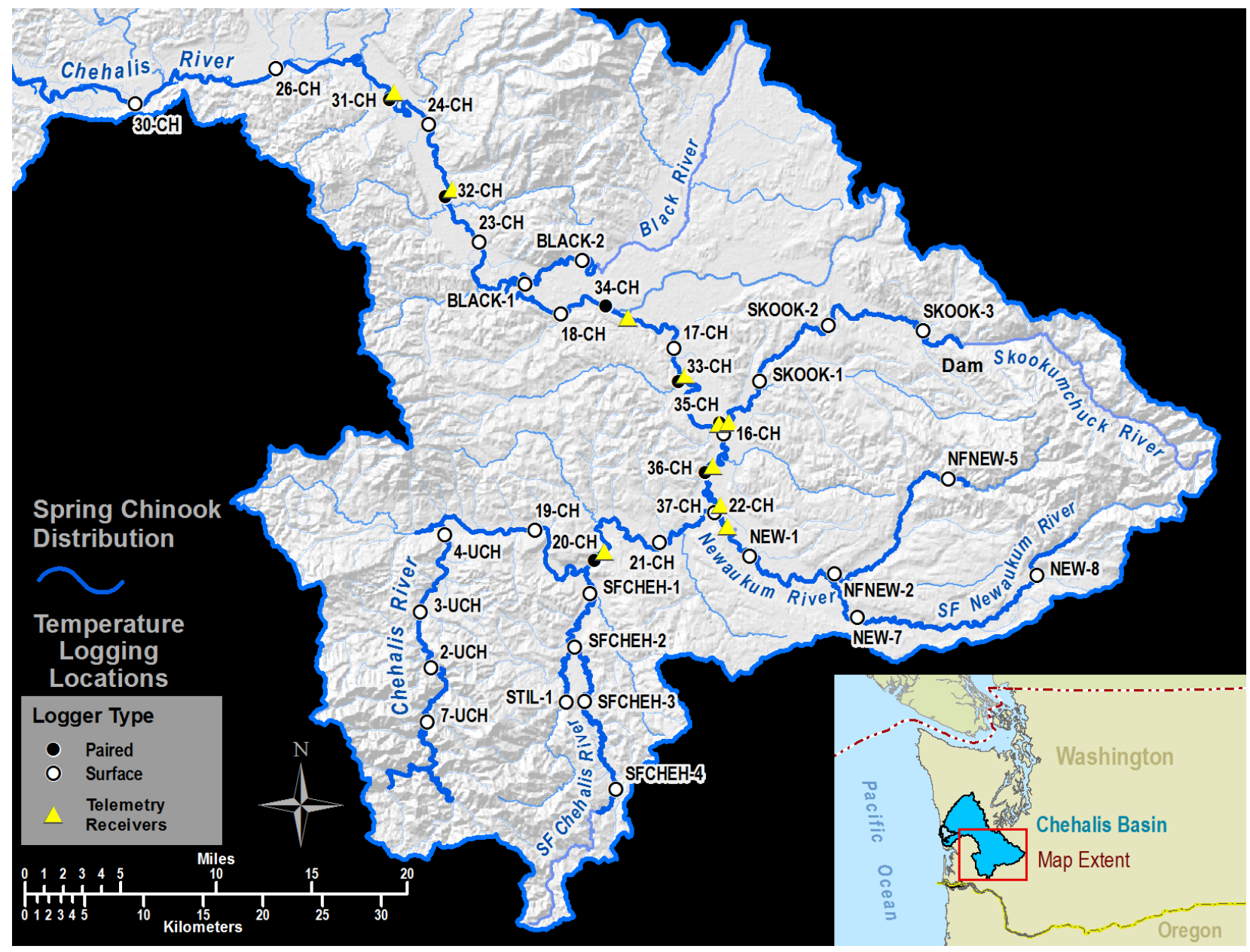

Figure 1. Schematic showing locations of fixed-site telemetry monitoring stations and temperature loggers in the Chehalis River Basin, southwestern Washington, 2015. 


\section{Methods}

\section{Study Site}

The Chehalis River Basin in southwestern Washington has a drainage area of about $6,900 \mathrm{~km}^{2}$ or about 2,664 $\mathrm{mi}^{2}$ (Smith and Wenger, 2001; fig. 1). Subbasins within the basin drain from the Willapa Hills, the foothills of the Cascade Mountains, and the Olympic Mountains. The river terminates in Grays Harbor, an estuary of the Pacific Ocean, near Aberdeen, Washington. Land uses include commercial forest, agriculture, and urban development (Hiss and Knudsen, 1993). The rain-dominant hydrology of the Chehalis River Basin is characterized by peak flows during winter and low flows during summer. The Chehalis River supports a diversity of native fish species including steelhead (Oncorhynchus mykiss), cutthroat trout (O. clarkii), Chinook salmon (O. tshawytscha), coho salmon (O. kisutch), and chum salmon (O. keta). Stock assessment of these populations includes spawning ground surveys conducted annually by the WDFW, Quinault Indian Nation, and Confederate Tribes of the Chehalis Reservation. Studies of fish distribution and ecology in the Chehalis River have largely focused on use of off-channel and estuarine habitats (Moser and others, 1991; Fresh and others, 2003; Henning and Schirato, 2006; Henning and others, 2007, Kuehne and Olden, 2016).

\section{Radio Transmitters}

The transmitters used for the study were from Lotek ${ }^{\odot}$ Wireless Incorporated (Newmarket, Ontario, Canada) model MCFT2-3EM. The tags were $52 \mathrm{~mm}$ long, with a diameter of $12 \mathrm{~mm}$, and weighed $10 \mathrm{~g}$ in air. The battery of the tag was designed to provide a minimum of $419 \mathrm{~d}$ of tag life, with an average tag life of $523 \mathrm{~d}$. Each tag was equipped with a temperature sensor that could record water temperatures from -6 to $34{ }^{\circ} \mathrm{C}$, and was specified by the manufacturer to be accurate to $\pm 0.8^{\circ} \mathrm{C}$.

The collection of tags used for the study was from two sources. About one-half of the tags were purchased in 2014 for a different study, but were either not used in fish or were used and then later recovered. These tags were stored through the winter of 2014-15 and were used for this study starting in spring 2015. The remaining tags were purchased and manufactured in 2015. The 2014 tags were all on a single frequency $(167.400 \mathrm{MHz})$ and the 2015 tags were all on a separate frequency $(164.144 \mathrm{MHz})$. Throughout this report, tags are reported as unique tag identification numbers (IDs) using two digits of the frequency along with the unique code for a given transmitter. For example, tag ID 40029 is on frequency $167.400 \mathrm{MHz}$, code 29, and tag ID 14011 is on frequency $164.144 \mathrm{MHz}$, code 11 . In addition to using tag IDs, each study fish was assigned a number (1-23) to increase readability of the report.

Controlled laboratory testing was conducted prior to the start of the study to evaluate the accuracy of the transmitter temperature sensors. Methods and results of the pre-season laboratory testing are presented in appendix A. Some temperature sensors appeared to be malfunctioning during the field evaluation. The temperature readings from these sensors were substantially different from the known ambient water temperatures, and there were concerns that the sensors were not accurately reporting temperature. To address these concerns, several of the transmitters in question were recovered and were evaluated in controlled tests after the field evaluation was complete. The findings of these post-season sensor evaluations are presented in appendix A. 


\section{Fish Collection, Tagging, and Release}

Adult spring Chinook salmon were not heavily concentrated in the study area, which made collection of fish for tagging one of the most challenging aspects of this study. Two approaches, hook and line angling and tangle nets, were used to maximize the number of fish available for tagging. Angling was conducted from a drift or jet boat on the main-stem Chehalis River from river mile (RM) 67.0 (Borst Park boat launch at mouth of the Skookumchuck River) to RM 20.2 (mouth of the Satsop River), beginning in late April 2015. In this reach, angling effort focused on known Chinook salmon holding areas using the expertise and assistance of local fishermen and fishing guides. By early June, low river flows and warming temperatures contributed to the growth of aquatic vegetation that tangled fishing lines and limited angling effectiveness. As a result, hook and line sampling efforts shifted downstream of the Satsop River mouth to take advantage of the cooler temperatures from the Satsop River as compared to the main-stem Chehalis River. Tangle nets $(18.3 \mathrm{~m}$ long $\times 7 \mathrm{~m}$ deep, with $8.3-\mathrm{cm}$ mesh) were a second collection technique used in the main-stem Chehalis River and the South Fork Newaukum River where Chinook salmon were observed to be holding. In the main-stem Chehalis River, sampling efforts by the Chehalis Tribe were conducted near Cedar Creek (RM 38.7). In June, collection efforts shifted to the South Fork Newaukum River where potential fishing locations were identified using snorkel surveys. Hook and line angling was the first capture method used in the South Fork Newaukum River followed by a snorkeler "herding" technique that proved to be the most effective for capture. Once a Chinook salmon was identified, snorkelers herded the fish towards the tangle net positioned at the bottom of the pool. Several passes through the holding pool were used to drive the fish downstream. A similar technique was used on the Skookumchuck River with no success because limited visibility made it difficult to identify holding fish. All fish collection and tagging efforts were terminated in early July because of concerns over handling fish at high water temperatures. Data recorded on the collection effort included date, water temperature, sex, fork length, hook size, line weight, bait or lure, hook location, and fish condition.

Fish-handling procedures aimed to minimize exposure to air; to keep fish in cool, well oxygenated water; and to minimize disturbances (Kelsh and Shields, 1996). Tagging and release were conducted at the collection site so fish were released near the location where they were originally collected. Fish collected by hook and line angling were removed from the water in a net (hoop dimensions, $94 \times 102 \mathrm{~cm}$ ) and transferred to a dark-colored holding tote (204-L volume; tote dimensions, $108 \times 55 \times 47 \mathrm{~cm}$ ). Fish captured with a tangle net were placed directly from the net into the tote. The holding tote was perforated to allow continuous exchange of water. During the tagging process, the tote was held in about $1 \mathrm{~m}$ of flowing water to ensure continuous circulation. Tagging locations were selected with gravel or cobble substrate (little to no fine substrates or sand) to reduce the amount of suspended sediments in circulation. The condition of the fish was examined and fish were rejected if it had been hooked deep in the throat or the gills and the hook could not be removed readily, or if it was otherwise negatively affected by the capture technique. 
Once a captured fish was selected for tagging, a glycerin-coated tag was inserted using techniques described by Keefer and others (2004). Fish were submerged in the holding tote throughout the tagging process. The recorded tagging data included tag ID and tagger name.

Following tag insertion, fish were allowed to recover in the holding tote, which was covered and submerged in the river. Two foam cylinders were attached near the tote lid to aid with floatation and to keep the tote upright. After 5 min of recovery time, tag placement and fish condition were evaluated by visual observation and by grasping the caudal peduncle to assess resistance to restraint. Fish that showed strong resistance to restraint were released to the river by submerging the edges of the holding tote to allow the fish to swim away. Fish that showed limited resistance to restraint were held an additional 5 min for recovery. After $10 \mathrm{~min}$ in the holding tote, fish were re-evaluated for their readiness to swim. Fish showing strong resistance to restraint were released. Fish showing limited resistance or those that generally were lethargic were not used in the study; the inserted tags were removed and the fish were released. Data recorded at the time of release included recovery time (5 or $10 \mathrm{~min}$ ), release location, and release time.

\section{Telemetry Monitoring}

A combination of fixed-site monitoring locations and mobile tracking efforts were used to collect information on the behavior, movement patterns, and temperature selection of tagged fish in the study area (fig. 1). The goal of the fixed-site monitoring array was to identify the timing of fish movements through the main-stem Chehalis River and the temperature exposures of tagged fish during their migration. Temperature exposure, as detected from the transmitter sensor, was compared to ambient water temperature by coupling the locations of the telemetry array with temperature loggers (see section, "Water Temperature Monitoring"). The array of fixed-site monitoring locations (hereinafter "fixed sites") included eight sites, beginning at RM 31.4 on the Chehalis River and continuing to RM 91.0 (table 1). In addition to these sites, there was a fixed site 0.4 river miles upstream of the mouth of the Skookumchuck River and a fixed site 1.5 river miles upstream of the mouth of the Newaukum River (table 1). These two sites were designed to detect fish as they entered these tributaries. Each fixed site included a telemetry receiver tuned to monitor the frequencies of the transmitters, an aerial antenna (or a combination of antennas), and a power source to supply the receiver. The fixed-site array was installed in early April 2015 and was maintained until November 17, 2015, when it was removed. The fixed sites were visited regularly to maintain effective operation and to secure data recorded on the receivers. 
Table 1. Locations of fixed-site monitoring stations in Chehalis River Basin, southwestern Washington, 2015.

[Locations are referenced based on river miles from the mouth of the Chehalis River. River mile designations for Skookumchuck and Newaukum Rivers are based on Chehalis River river mile distances to tributary junction, plus distance in river miles upstream in tributary. WA, Washington]

\begin{tabular}{lcl}
\hline \multicolumn{1}{c}{ River } & $\begin{array}{c}\text { Location } \\
\text { (river mile) }\end{array}$ & \multicolumn{1}{c}{ Description/Reference } \\
\hline Chehalis & 31.4 & Midway between the towns of Porter and Saginaw, WA, near Eaton Creek. \\
Chehalis & 41.1 & Downstream of the town of Oakville, WA, at the mouth of Cedar Creek. \\
Chehalis & 58.7 & South of the town of Rochester, WA, upstream of the mouth of Scatter Creek. \\
Chehalis & 65.1 & Downstream of the town of Galvin, WA, near Lincoln Creek. \\
Chehalis & 69.8 & 0.2 river miles downstream of the confluence of the Skookumchuck and \\
Skookumchuck & 70.4 & Chehalis Rivers. \\
Chehalis & 74.8 & Midway between the mouths of the Newaukum and Skookumchuck Rivers. \\
Chehalis & 78.7 & Newaukum River mouth. \\
Newaukum & 80.3 & 1.5 river miles upstream of the mouth of the Newaukum River. \\
Chehalis & 91.0 & Upstream of the town of Millburn, WA. \\
\hline
\end{tabular}

The goal of the mobile tracking was to identify fish locations and temperature exposures during time periods when they were not detected at the fixed sites, and in areas not monitored by the fixed sites (for example, the tributaries). Mobile tracking was conducted from early May through mid-October 2015, with weekly surveys conducted after the first week of July. Mobile tracking efforts covered all potential areas where tagged fish were thought to be holding. Tracking efforts focused on areas with previous mobile detections of tagged fish and areas identified as potential fish locations using reports generated from the fixed sites. Tracking was conducted with a hand-held telemetry receiver and an aerial antenna. Once a fish was detected, the tracker moved toward the fish location while lowering the gain on the receiver to refine the fish position. Once the tracker was as close to the fish as possible, information was recorded on date, time, gain, location (latitude, longitude with Global Positioning System [GPS]), and a general description relative to known landmarks. The temperature reading from the tag sensor was only recorded if the tracker was able to acquire a consistent and strong reading for the tag for a minimum of $3 \mathrm{~min}$. When possible, the mobile tracker collected a surface-water temperature near the estimated location of the tagged fish to make comparisons between the ambient river temperature near the fish location and the temperature detected by the tag sensor. Tags were recovered from the river bottom or shorelines or fish carcasses whenever possible to assist with assignments of fate. In September and October, mobile tracking teams attempted to determine whether tagged fish were spawning. 


\section{Water Temperature Monitoring}

\section{Stream Temperatures}

Digital thermographs, or loggers, were deployed at 36 locations in 2015. Sites were selected to cover the entire known distribution of spring Chinook salmon in the Chehalis River based on the WDFW SalmonScape database (Washington Department of Fish and Wildlife, 2016) and observations by WDFW fish management biologists (fig. 1). Spatial coverage included the main-stem Chehalis River from the confluence with the Wynoochee River to the confluence with Elk Creek. Spatial coverage also included the Chehalis River upstream of the Elk Creek confluence; results from this area were summarized as the upper Chehalis subbasin. In addition to the upper Chehalis subbasin, spatial coverage included the Black River, Skookumchuck, Newaukum, and South Fork Chehalis subbasins. At all sites, loggers were deployed to determine temperatures of surface waters throughout the summer. At eight sites along the main-stem river, loggers were paired between surface water and deep water microsites. The paired loggers were deployed in areas identified by local guides and anglers as locations where spring Chinook salmon are caught in the main-stem Chehalis River.

Temperature loggers (Onset Hobo ${ }^{\circledR}$ Pendant 64K, Onset Computer Corporation, Bourne, Massachusetts, accuracy $\pm 0.5^{\circ} \mathrm{C}$ ) collected stream temperature data at 30-min intervals between April and September 2015. The loggers were secured in white plastic vinyl carbonate (PVC) housings with openings that allowed flowing water to contact the logger. Surface loggers were positioned in flowing water out of direct sunlight. Depending on site characteristics, the logger and housing was secured using an epoxy (Isaak and others, 2013) or cable system. Deep water loggers were anchored with cable and were weighted to the deepest point of the channel using sand bags attached to the cable or rocks placed inside the PVC housing. All loggers were downloaded on a monthly basis, providing in-season checks on the integrity of the site and data time series. Missing or malfunctioning loggers were replaced during the monthly checks or as soon thereafter as possible.

The accuracy of each logger was compared to a National Institute of Standards and Technology (NIST) reference thermometer prior to being deployed and upon retrieval to ensure that temperature deviations did not exceed $0.5^{\circ} \mathrm{C}$. Erroneous temperature data were removed prior to analysis using three levels of screening. Loggers were inspected for positioning and submersion during routine field visits. Downloaded data were plotted by time and the data series was visually inspected for outliers or deviations from neighboring loggers. Finally, data were removed if the rate of change on a given day exceeded $2.5^{\circ} \mathrm{C}$ per hour, which likely indicated that the logger was out of water during that period of time (Rieman and Chandler, 1999).

To describe the temporal and spatial variability in stream temperature, three monthly temperature metrics were calculated for each surface logger - mean, mean daily minimum, and mean daily maximum. Scatter plots fitted with LOWESS smoothed regression curves were used to visualize the contrast in temperatures over time (temporal variability) and the relation between temperature and elevation (spatial variability). These patterns were compared between the main stem and each of the five subbasins included in the study area. 
To describe the vertical variability in stream temperature between surface and deep microsites, a line plot of maximum daily temperatures (5-d rolling average) over time was plotted for surface and deep loggers at each of the locations. Vertical variation was further described by calculating the proportion of days (June-August) that the difference between the surface and deep loggers at each location exceeded $1{ }^{\circ} \mathrm{C}$.

\section{Bathythermograph Surveys}

Bathythermograph (hereinafter "BT") surveys were conducted monthly on the Chehalis River at the mouths of the Skookumchuck and Newaukum Rivers from May to October 2015. An extra survey was conducted during April at the Skookumchuck River. No survey was done at the Newaukum River in April because of limited access. The goal of these surveys was to document the water temperatures and water depths available to spring Chinook salmon at these potential holding and transition areas for spring Chinook salmon. The 2014 pilot telemetry study showed that these tributary mouths were frequented by tagged fish (U.S. Geological Survey, unpub. data, 2014), so additional monitoring was focused in these areas in 2015 to better understand the microhabitats available to fish and their use of these areas. The methods used for the BT surveys were the same for both tributaries. Five transects were established: two transects in the Chehalis River upstream of the confluence with the tributary, two transects in the Chehalis River downstream of the confluence with the tributary, and one transect in the tributary (fig. 2). The transect positions were established on the first survey date and were used throughout the study. In addition to the five transects, three point locations at the junction of the two rivers were sampled (fig. 2). The total river length surveyed at each tributary was about 0.1 river mile, centered on the tributary mouth.

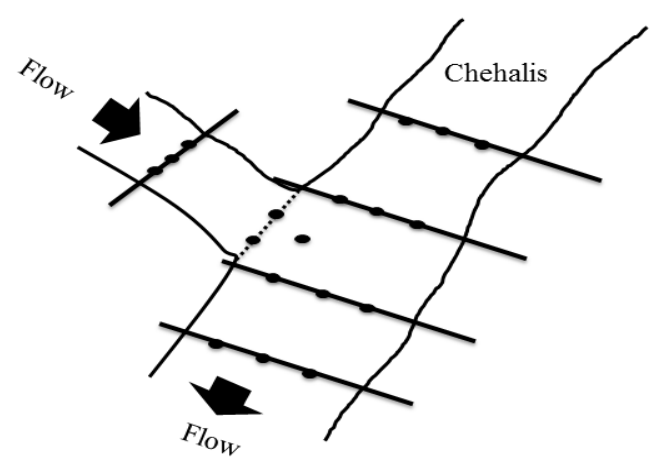

Figure 2. Diagram showing transects and points used to conduct monthly bathythermograph surveys of the junction of the Chehalis River with the Skookumchuck and Newaukum Rivers, southwestern Washington, 2015. Lines represent the transects established for sampling, and points (both on and off the transects) show the locations where water depth and water temperature data were collected. 
Three sampling points were established on each of the five transects. The total wetted width of the channel was measured on each visit using a tape measure. Sampling points were established at 25, 50, and 75 percent of the measured total wetted channel width. Sampling points on the transects were determined on each sampling date (based on wetted channel width) and were recorded with a GPS during sampling. A weighted line was used to sample depth and water temperature at each sampling point. The sampling line was $4 \mathrm{~m}$ long, with temperature loggers (Onset Hobo ${ }^{\circledR}$ Pendant 64K, Onset Computer Corporation, Bourne, Massachusetts, accuracy $\left.\pm 0.5^{\circ} \mathrm{C}\right)$ positioned at the terminal end $(0 \mathrm{~m}$ depth) and every $0.5 \mathrm{~m}$ along the length of the line. Temperature loggers were compared to a NIST thermometer prior to use and were confirmed to be within specifications. Water depth was measured at each sampling position using a measuring stick, and the sampling line was lowered to the river bottom and held taut at the top. The sampling line was left in position for $2 \mathrm{~min}$ to allow the temperature loggers to adjust to ambient conditions, then 3 min longer to collect the BT data for the sampling point. Additional point samples were collected if the main tributary channel was divided on a sampling date. All sampling at each site was completed within a few hours to control for water temperature variability. Both tributaries were sampled within a day of each other every month to limit environmental variation.

Water depth and temperature measurements were processed and depicted graphically. The mean water temperature over the 3-min sampling period for each sampling point was calculated and correlated with the depth and GPS position of the sample. A graphics program (Tecplot $360^{\mathrm{TM}}$, Tecplot, Incorporated, Bellevue, Washington) was then used to generate flood plots of the sampled area. The sample points were used to interpolate temperature and depth to a rectangular volume encompassing the extent of all sample points. The rectangular volume was refined using the maximum depth recorded so that a stream bottom contour was defined. Slices of each tributary area, about $20 \mathrm{~m}$ apart, were generated to represent the BT profile of the study area.

\section{Analysis}

Fish movements were summarized from a dataset that combined all fixed-site detections and all mobile tracking detections for each individual study fish. Fixed-site detections logged prior to the recorded time of release and those with low signal strength $(<200)$ were removed from the detection dataset. A detection history was generated for each study fish and was used to summarize fish movements. Fish detections in the main-stem Chehalis River were a combination of fixed-site and mobile-tracking detections, as both monitoring methods were used in this part of the study area. Fish detections in the Newaukum River (upstream of river mile 1.5), however, were all from mobile tracking efforts as the fixed-site monitoring array did not extend substantial distances into the tributaries. Fish movements were summarized separately for fish tagged in the Chehalis River and those tagged in the Newaukum River.

The timing of fish movements and the maximum displacement from the release location were summarized. Fish location (by river mile) was plotted by date in the main-stem Chehalis River as spring Chinook salmon migrated upstream and were detected at the fixed sites. This summary showed the rate at which fish moved through the river and any areas of extended holding between fixed sites during the study period. Location (by river mile) also was plotted by date for fish detected in the Newaukum River subbasin. Many of the Chinook salmon were tagged after they entered the Newaukum River so these data could not be used to understand the rate of upstream migration. The location by date information within the Newaukum River showed the extent of movements and holding areas during the study period. The maximum displacement for individual fish was calculated as the distance between the release location and the detection location that was the farthest away from the release location. The mean maximum displacement for a group of fish was reported, along with the lowest and highest maximum displacement distance. 
Water temperatures for tagged fish were summarized based on tag temperature sensor data collected by the fixed sites or mobile tracking. Tag temperature sensor data were reviewed before analyses were conducted. As the performance of some tag sensors was questionable during the study period, the temperature records for these fish were not included in any analyses. All other tag sensor data were carefully reviewed. Data from the sensor were used for analyses if the signal strength for the detection record was high $(>150)$, there were several similar readings within a short time period (minutes), and the temperature was reasonable (within about $5^{\circ} \mathrm{C}$ ) when compared to the water temperature near where the tag was located. If sensor data failed to meet these criteria, they were removed from the temperature dataset and were not included any analyses of fish temperature exposure or selection. Finally, if the tag was documented to have been removed from the water (for example, harvested, predated, or in a dead fish), the sensor data were not used for analyses as the specific timing of removal could not be confirmed.

Temperature selection by tagged fish was examined by comparing the tag temperature sensor data to measures of ambient river temperature. Tag temperature sensor data were combined with ambient river temperature data using the detection history for a given fish, which provided a location, date, and time. For fish detected at the fixed sites, the temperature logger paired with that fixed site was used to represent the ambient water temperature. Tag sensor temperature was averaged over the period of time that the fish was detected at the fixed site. Ambient river temperature at the location and time of detection was calculated as the average of logger temperature (deep and shallow loggers, if available) for the period when the fish was present at the fixed site. In cases where the fish was detected at the fixed site for a short period ( $<10 \mathrm{~min}$ ), the logger data were averaged for the $5 \mathrm{~min}$ prior to the detection and the $5 \mathrm{~min}$ after the fish was no longer detected. For fish detected by mobile tracking, the fish location was used to find a companion ambient water temperature. For each mobile tracking detection the tag sensor temperature was a single value. Ambient river temperature at the fish location and time of detection was calculated from temperature loggers immediately upstream and downstream of the fish location. Using the date and time of the tag temperature sensor record, the average temperatures of both upstream and downstream loggers were calculated for the period $30 \mathrm{~min}$ prior to and after the fish detection. Ambient temperature at the fish location was estimated from the temperature difference between the two temperature loggers and the relative distance that the fish was located between the temperature loggers. Fish location was converted to the nearest river mile using ArcView ${ }^{\mathrm{TM}}$ software (Environmental Systems Research Institute, Incorporated, Redlands, California) to "snap" the location of the fish detections to a common center line for the river.

Each tagged fish was assigned a final fate based on the detection history and information from tag recoveries. Four potential fates were defined: pre-spawn mortality, spawner, spit/mortality, and unknown. Fish were assigned a pre-spawn mortality fate if there was evidence that the fish and (or) the tag were actively removed from the river during the study period, either through a predation or a harvest event (for example, if the tag was recovered above the waterline on the river bank). In some cases, the fish was confirmed to have been harvested. A fate of spawner was assigned if a fish was known to survive to the spawning period (defined as starting on September 1,2015) and was located in a potential spawning area during the spawning period. All fish that met this criteria were potentially spawning fish, and a subset of these fish had tags recovered near redds and (or) spawned-out carcasses and were further identified as confirmed spawners. A fate of spit/mortality was assigned to fish with little evidence of movement after tagging. As the tags were gastrically implanted into study fish, they could have been regurgitated or "spit". A spit tag commonly will fall to the bottom of the river and remain stationary, presenting a detection history similar to that of a dead fish. This fate assignment suggests that fish had a negative response to capture, handling, or tagging, leading to death or a spit tag, or the fish died of natural causes some time prior to spawning. Finally, a fate of unknown was assigned to fish where information was lacking to provide evidence for any other fate. 


\section{Results}

\section{Fish Collection, Tagging, and Release}

A total of 23 spring Chinook salmon were collected, radio-tagged, and released for the study (table 2). Spring Chinook salmon were collected and tagged from late-April to early-July 2015. The primary goal for fish collection efforts was to capture fish as low in the river as possible so that their upstream movements and timing could be monitored. An adaptive management approach was used to mitigate challenges with fish collection in the lower Chehalis River, leading to efforts to collect fish for tagging in the Newaukum River. Ultimately, similar numbers of spring Chinook salmon were tagged and released into the main-stem Chehalis River (11 fish) and South Fork Newaukum River (12 fish; table 2).

The 11 fish from the Chehalis River group were collected primarily by hook and line angling (10 fish). One fish was collected using a tangle net (table 2). Six fish were captured and released near RM 19.9 on the Chehalis River, and the remaining fish were collected at RM 27.9 (two fish), RM 37.3 (one fish), RM 43.9 (one fish), and RM 47.0 (one fish). The mean fork length of the fish in the Chehalis River group was $76 \mathrm{~cm}$, with a minimum fork length of $62 \mathrm{~cm}$ and a maximum fork length of $85 \mathrm{~cm}$. Of the 11 tagged fish from this group, 8 fish were females and 3 fish were males.

Table 2. Number of spring Chinook salmon collected, radio-tagged, and released for study, Chehalis River Basin, southwestern Washington, 2015.

[Details include the date fish were collected, tagged, and released, the number of fish tagged on each date, description of capture and release location (fish were released near the point of capture), gear used to capture fish, and sex of fish]

\begin{tabular}{lclll}
\hline \multicolumn{1}{c}{ Date } & $\begin{array}{c}\text { Number of } \\
\text { fish } \\
\text { collected, } \\
\text { tagged, and } \\
\text { released }\end{array}$ & \multicolumn{1}{c}{ Capture/release location } & \multicolumn{1}{l}{ Capture gear } & Sex \\
\hline April 27, 2015 & 2 & Chehalis River & Hook and line & 1 female, 1 male \\
May 15, 2015 & 2 & Chehalis River & Hook and line & 1 female, 1 male \\
June 11, 2015 & 2 & South Fork Newaukum River & Tangle net & 1 female, 1 male \\
June 15, 2015 & 2 & South Fork Newaukum River & Tangle net, hook and line & 1 female, 1 male \\
June 16, 2015 & 2 & Chehalis River & Hook and line & 2 females \\
June 17, 2015 & 2 & Chehalis River & Hook and line & 1 female, 1 male \\
June 18, 2015 & 4 & South Fork Newaukum River & Tangle net & 3 females, 1 male \\
June 22, 2015 & 2 & Chehalis River & Tangle net, hook and line & 2 females \\
June 25, 2015 & 1 & Chehalis River & Hook and line & 1 female \\
July 01, 2015 & 4 & South Fork Newaukum River & Tangle net & 2 females, 2 males \\
Totals & 23 & Chehalis River: 11 & & 8 females, 3 males \\
\hline
\end{tabular}


The 12 fish from the South Fork Newaukum River group were collected primarily by tangle net (11 fish). One fish was collected using hook and line angling (table 2). All fish from the South Fork Newaukum River group were collected between RMs 9.2 and 11.2 (21.1-23.1 river miles upstream of the confluence with the Chehalis River). The mean fork length of the fish in the South Fork Newaukum River was $73 \mathrm{~cm}$, with a minimum fork length of $62 \mathrm{~cm}$ and a maximum fork length of $84.5 \mathrm{~cm}$. Of the 12 tagged fish from this group, 7 fish were females and 5 fish were males.

\section{Water Temperatures}

Water temperature and flow conditions in the main-stem Chehalis River during summer 2015 were atypical compared to historical averages. Mean monthly water temperatures between March and July 2015 were higher than any decade since 1960 (fig. 3A). Water temperatures were greater than average starting early in the spring, and continued into the late summer (fig. 3A). Mean daily temperatures in the main-stem Chehalis River were $2-5{ }^{\circ} \mathrm{C}$ higher between May and July 2015 than in previous years. Additionally, the mean daily flows in the Chehalis River were lower than the average flows for any decade since the 1960s (fig. 3B). Mean daily flows in the main-stem Chehalis River between May and July 2015 were 30-70 percent of the flows in a similar time frame in previous years (fig. 3B).
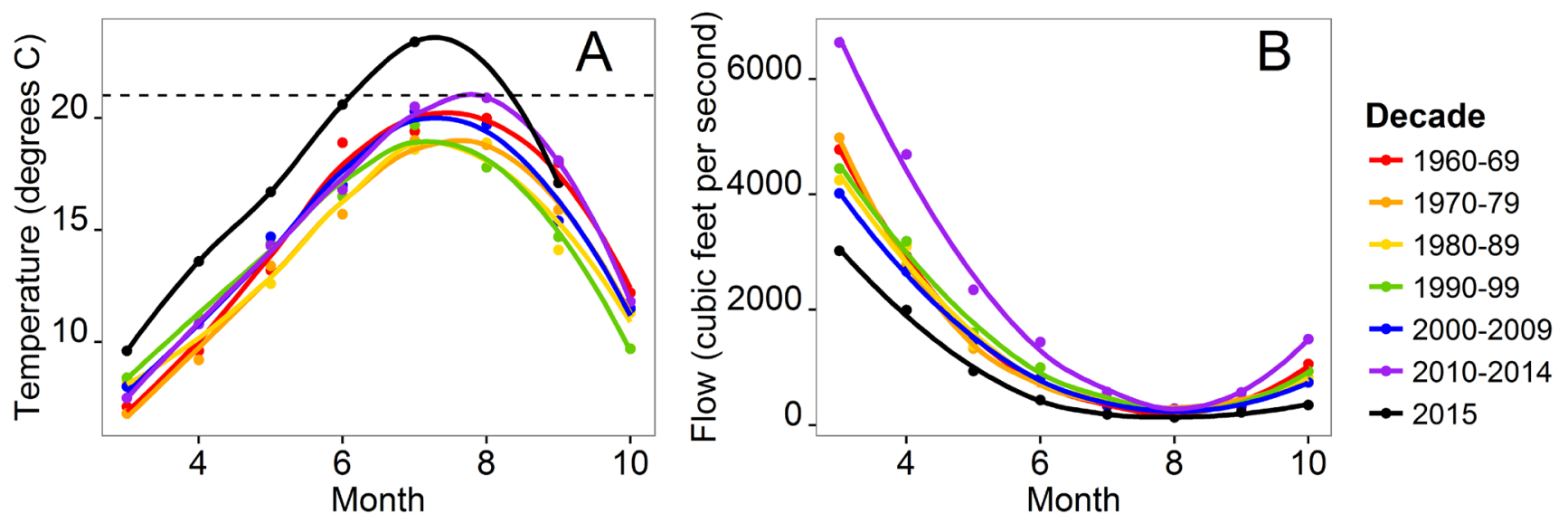

Figure 3. Graphs showing water temperature and flows of the main-stem Chehalis River, southwestern Washington, 1960-2015. Water temperatures are monthly measures obtained from Station 23A070 (Washington Department of Ecology) near Porter, Washington. Horizontal dashed line at $21^{\circ} \mathrm{C}$ is added for reference. Streamflows are the monthly average of daily measurements obtained from USGS streamgage Chehalis River near Grand Mound, Washington (12027500). Data shown are decadal averages fit with a LOWESS smoothed regression curve. Data for 2015 are shown separately and were still in provisional status at the time this report was produced. 
Spatial and Temporal Variability

A summary of stream temperature metrics for each study site is provided in appendix B. At all locations within the study area, stream temperatures were warmest in July (fig. 4). The maximum daily temperatures exceeded $21{ }^{\circ} \mathrm{C}$ in the main-stem river throughout June, July, and August. During this mid-summer period, the main-stem river was consistently warmer than each of the individual subbasins, and the Newaukum and Skookumchuck subbasins were consistently cooler. The largest temperature difference between the main-stem river and tributaries occurred in July $\left(5.2^{\circ} \mathrm{C}\right.$ difference between maximum daily temperatures of the main-stem Chehalis River compared to the Skookumchuck River).

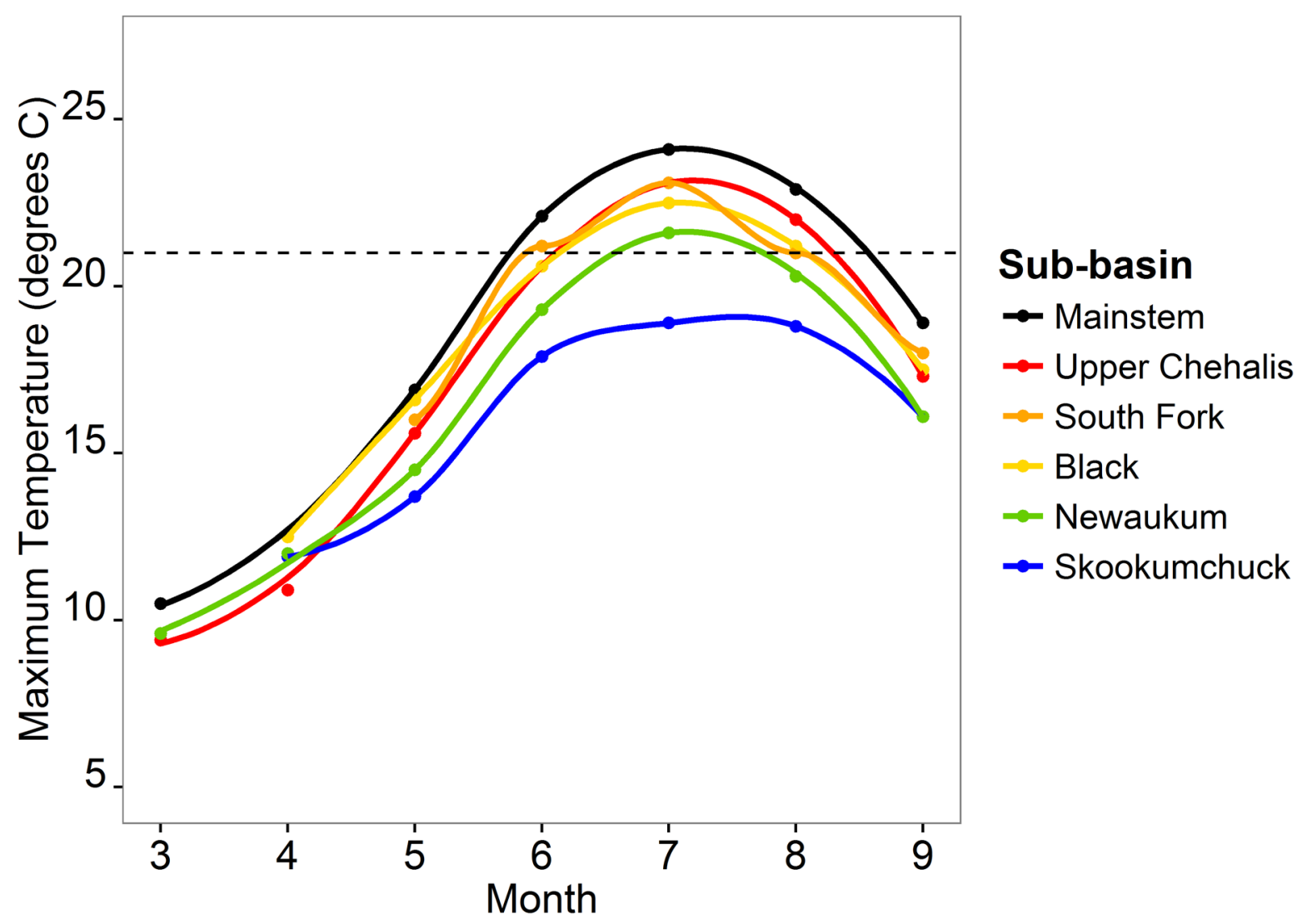

Figure 4. Graph showing maximum stream temperature by month in the subbasins of the Chehalis River Basin, southwestern Washington, March-September 2015. Data are mean of maximum daily temperature values. Each subbasin is plotted separately and fitted with LOWESS smoothed regression curve. Horizontal dashed line at $21^{\circ} \mathrm{C}$ is added for reference. 
Stream temperature was related to elevation in all subbasins, with the exception of the Black River, which had just a 5-m (16.4-ft) change in elevation between the logger locations (fig. 5). Upstream of the South Fork Chehalis River (logger 20-CH in fig. 1, elevation 202-ft in fig. 5A-5B), the temperature of the main-stem Chehalis River decreased with increasing elevation. A similar pattern of decreasing temperatures with increasing elevation was observed in the South Fork Chehalis River (fig. 5C), Newaukum River (fig. 5E), and Skookumchuck River (fig. 5F). In contrast, temperature of the Chehalis River increased with increasing elevation between the confluence with the Wynoochee River (logger 30-CH in fig. 1, elevation 7-ft in fig 5A) and South Fork Chehalis River, resulting in a concave relation between temperature and elevation over the entire $190 \mathrm{~km}(118 \mathrm{mi})$ of main stem included in the study area (fig. 5A-5B).

\section{Vertical Variation at Select Main-Stem Locations}

Temperature differences between depths were observed throughout the summer with the temperature of the deep logger always equal to or less than that of the surface logger (fig. 6). The proportion of time during June-August that paired surface-deep microsites differed by more than $1{ }^{\circ} \mathrm{C}$ was highly variable and ranged from about 0 to 0.90 (table 3). Although surface-deep differences were observed at six of eight locations, the maximum temperatures of the deep microsites ranged from 20.2 to $23.4^{\circ} \mathrm{C}$. One location, RM 74.7, showed the most consistent evidence of stratification. The JuneAugust differences between surface and deep temperatures were consistently greater than $1{ }^{\circ} \mathrm{C}$, and the maximum temperature of the deep microsite in these months was cooler than that of any of the other main-stem locations.

Data gaps in the time series occurred at four of eight sites because of the unauthorized removal of temperature loggers. Monthly visits to the sites minimized the data loss and loggers were replaced when needed. The removal of loggers was most problematic at one site (RM 64.3) where a new logger was reinstalled during three sequential monthly checks and found missing on the subsequent visit.

\section{Bathythermograph Surveys}

The BT surveys of the Chehalis River near the confluences with the Skookumchuck and Newaukum Rivers showed the same temporal changes in water temperatures as observed with the temperature loggers throughout the basin (figs. 7 and 8). Mean water temperature at the mouth of the Newaukum River mouth increased $9.7^{\circ} \mathrm{C}$ between May and June, moving from water temperatures that did not pose substantial risk to spring Chinook salmon $\left(12.9^{\circ} \mathrm{C}\right)$ to temperatures greater than the $21^{\circ} \mathrm{C}$ level of concern for salmonids $\left(22.6^{\circ} \mathrm{C}\right.$, table 4). Similarly, the increase in mean water temperature for the Skookumchuck River mouth between May and June was $8.8^{\circ} \mathrm{C}$, increasing from 13.1 to $21.9{ }^{\circ} \mathrm{C}$ (table 4). The mean water temperatures were greater than $21^{\circ} \mathrm{C}$ in both tributaries and both tributary mouths in June, July, and August (table 4). 

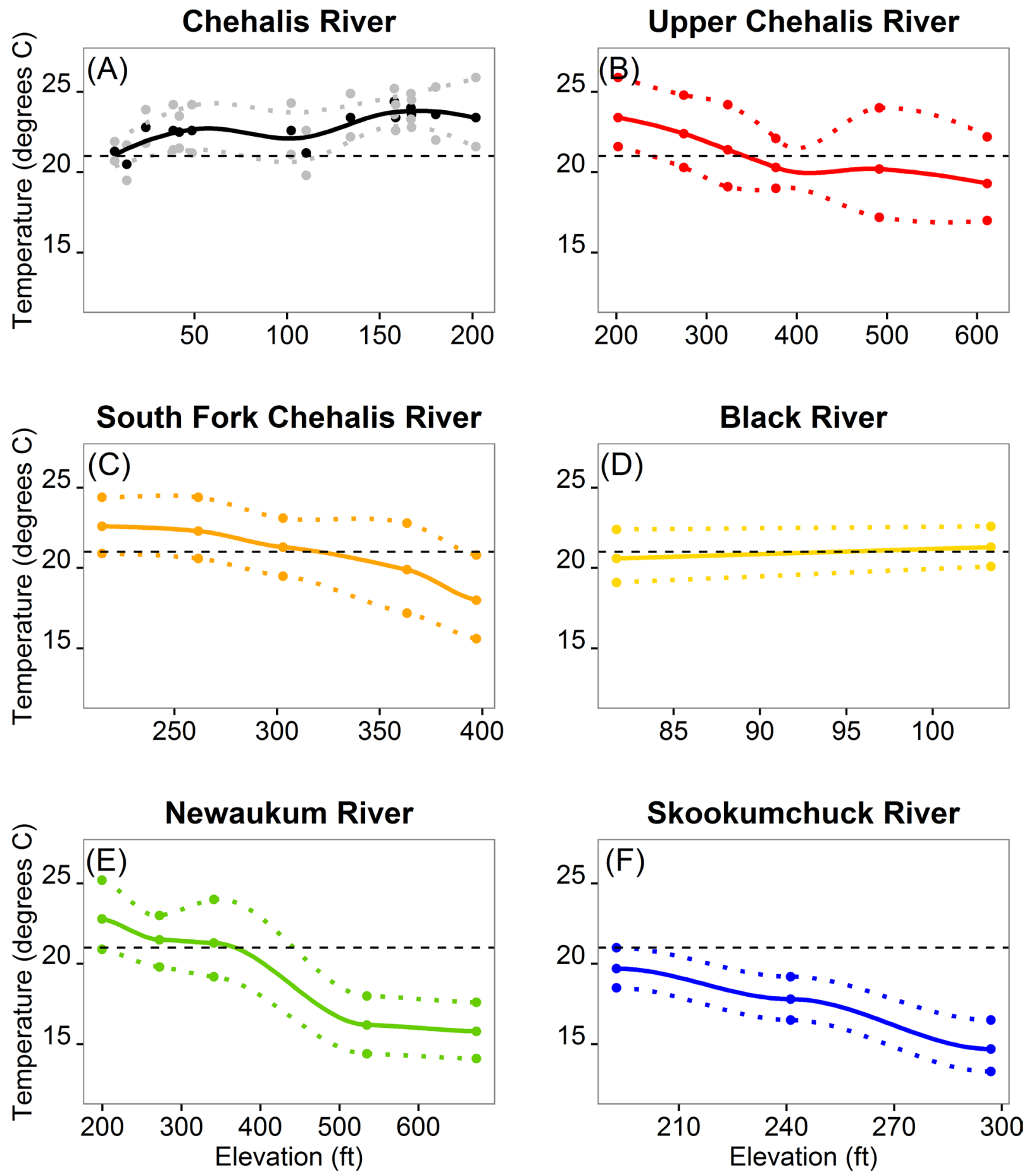

Figure 5. Graphs showing July stream temperatures by elevation in the Chehalis River Basin, southwestern Washington, 2015. Data are organized by the main-stem river (A) and individual subbasins (B-F). Points are data from individual loggers and lines are LOWESS smoothed regression curves. Solid line shows mean of average daily temperatures. Upper and lower dotted lines show mean of maximum and minimum daily temperatures, respectively. Horizontal dashed line at $21^{\circ} \mathrm{C}$ is added for reference. 
Table 3. Differences in water temperatures between surface and deep microsites at eight locations on main-stem Chehalis River, southwestern Washington, June-August 2015.

[Statistics include proportion of days that difference between surface and deep microsites exceeded 1 degree Celsius $\left({ }^{\circ} \mathrm{C}\right)$ (proportion $>1{ }^{\circ} \mathrm{C}$ ) and mean of daily maximum temperatures of deep microsite (deep maximum). Data are organized from downstream to upstream position based on river mile. Location of each Site ID is shown in figure 1]

\begin{tabular}{lclcc}
\hline Site ID & $\begin{array}{c}\text { River } \\
\text { mile }\end{array}$ & \multicolumn{1}{c}{ Site description } & Proportion $>1{ }^{\circ} \mathbf{C}$ & Deep maximum $\left({ }^{\circ} \mathrm{C}\right)$ \\
\hline $31-\mathrm{CH}$ & 30.4 & Near confluence of Eaton Creek & 0.34 & 22.1 \\
$32-\mathrm{CH}$ & 40.7 & Near confluence of Cedar Creek & 0.05 & 22.5 \\
$34-\mathrm{CH}$ & 56.7 & Near confluence of Scatter Creek & 0.00 & 22.9 \\
$33-\mathrm{CH}$ & 64.3 & Near confluence of Lincoln Creek & 0.00 & 21.5 \\
$35-\mathrm{CH}$ & 69.5 & Near confluence of Skookumchuck River & 0.11 & 22.1 \\
$36-\mathrm{CH}$ & 74.7 & Scheuber hole & 0.90 & 20.2 \\
$22-\mathrm{CH}$ & 78.5 & Near confluence of Newaukum River & 0.02 & 23.4 \\
$20-\mathrm{CH}$ & 92.5 & Downstream of South Fork Chehalis River & 0.62 & 22.6 \\
\hline
\end{tabular}

Table 4. Water temperatures and water depths from monthly bathythermograph surveys of the junction of Skookumchuck and Newaukum Rivers with main-stem Chehalis River, southwestern Washington, April-October 2015.

[Mean water temperature of main-stem Chehalis River (main-stem mean water temperature) was compared to mean water temperature in tributary to calculate the difference in water temperature. Shaded cells indicate mean water temperatures greater than 21 degrees Celsius $\left.\left({ }^{\circ} \mathrm{C}\right)\right]$

\begin{tabular}{|c|c|c|c|c|c|c|c|c|}
\hline Tributary & Survey date & $\begin{array}{c}\text { Mean } \\
\text { water } \\
\text { depth } \\
\text { (meters) }\end{array}$ & $\begin{array}{l}\text { Maximum } \\
\text { water } \\
\text { depth } \\
\text { (meters) }\end{array}$ & $\begin{array}{c}\text { Main-stem } \\
\text { mean water } \\
\text { temperature } \\
\left({ }^{\circ} \mathrm{C}\right)\end{array}$ & $\begin{array}{c}\text { Minimum } \\
\text { water } \\
\text { temperature } \\
\left({ }^{\circ} \mathrm{C}\right) \\
\end{array}$ & $\begin{array}{c}\text { Maximum } \\
\text { water } \\
\text { temperature } \\
\left({ }^{\circ} \mathrm{C}\right)\end{array}$ & $\begin{array}{c}\text { Mean water } \\
\text { temperature } \\
\text { in tributary } \\
\left({ }^{\circ} \mathrm{C}\right)\end{array}$ & $\begin{array}{l}\text { Difference in } \\
\text { water } \\
\text { temperature } \\
\left({ }^{\circ} \mathrm{C}\right)\end{array}$ \\
\hline Skookumchuck & April 30 & 2.0 & 2.7 & 14.0 & 13.3 & 17.1 & 13.8 & 0.2 \\
\hline Skookumchuck & May 14 & 2.1 & 2.8 & 13.1 & 12.1 & 13.5 & 12.3 & 0.8 \\
\hline Skookumchuck & June 11 & 1.8 & 2.6 & 21.9 & 17.2 & 23.1 & 16.7 & 5.2 \\
\hline Skookumchuck & July 8 & 1.7 & 2.4 & 25.9 & 23.2 & 27.8 & 23.2 & 2.7 \\
\hline Skookumchuck & August 6 & 1.7 & 2.3 & 22.8 & 20.6 & 24.0 & 20.7 & 2.1 \\
\hline Skookumchuck & September 9 & 1.7 & 2.4 & 18.3 & 17.8 & 19.4 & 18.2 & 0.1 \\
\hline Skookumchuck & October 13 & 1.8 & 2.5 & 16.0 & 14.5 & 16.5 & 14.4 & 1.6 \\
\hline Means1 & & 1.8 & 2.5 & 19.7 & & & 17.6 & 2.1 \\
\hline Newaukum & May 13 & 1.7 & 3.1 & 12.9 & 12.5 & 13.3 & 13.0 & 0 \\
\hline Newaukum & June 10 & 1.4 & 2.9 & 22.6 & 21.1 & 24.0 & 22.0 & 0.6 \\
\hline Newaukum & July 8 & 1.3 & 2.6 & 24.4 & 23.2 & 25.4 & 23.3 & 1.1 \\
\hline Newaukum & August 6 & 1.3 & 2.6 & 21.4 & 20.1 & 22.2 & 20.4 & 1.0 \\
\hline Newaukum & September 9 & 1.3 & 2.6 & 17.8 & 17.3 & 18.0 & 17.5 & 0.3 \\
\hline Newaukum & October 13 & 1.4 & 2.8 & 15.3 & 15.1 & 15.6 & 15.2 & 0.1 \\
\hline Means & & 1.4 & 2.8 & 19.1 & & & 18.6 & 0.5 \\
\hline
\end{tabular}

${ }^{1}$ Means for the Skookumchuck River do not include April to allow comparisons with the Newuakum River surveys where no data were available for April. 

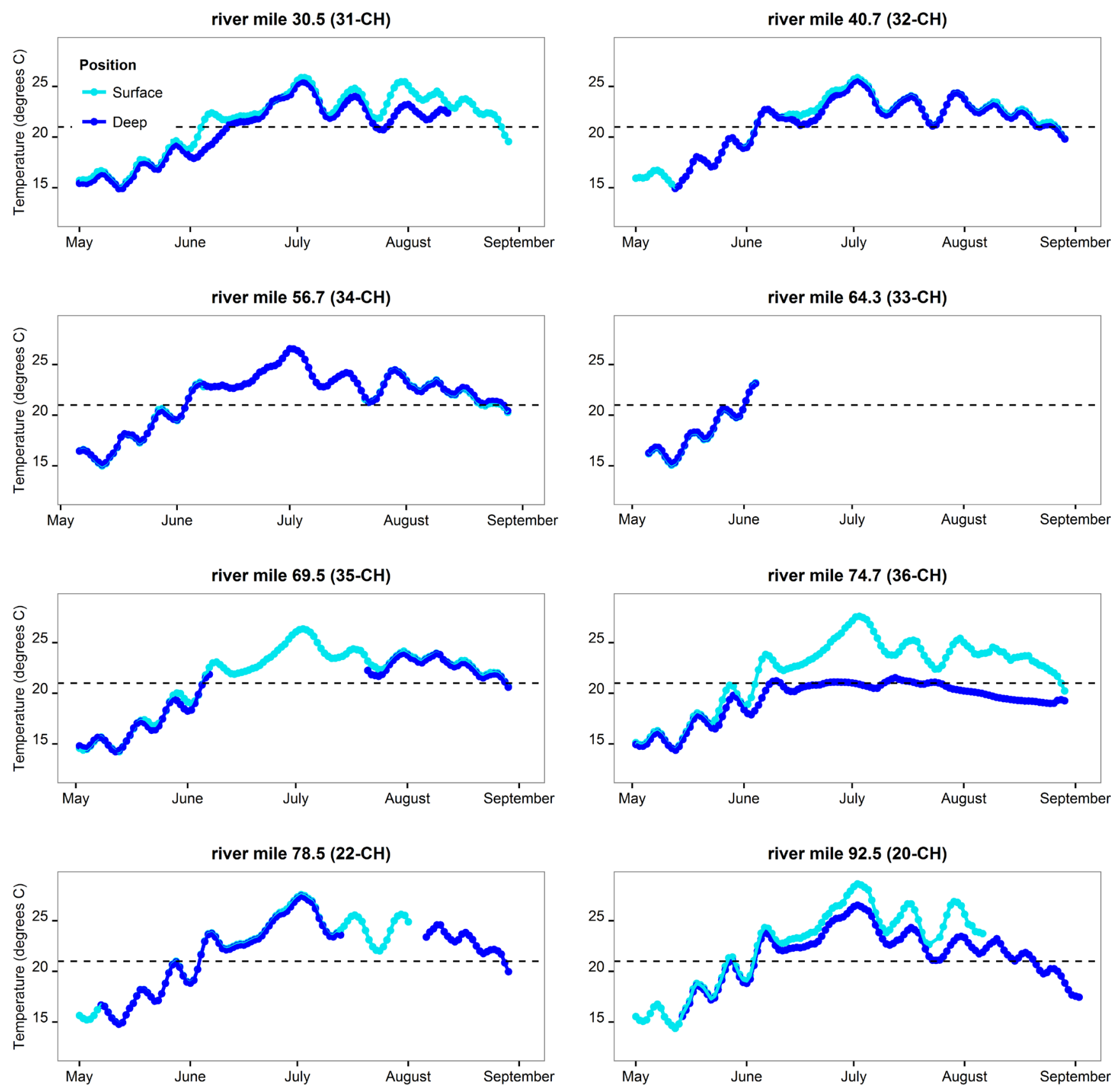

Figure 6. Graphs showing stream temperatures from "surface" and "deep" microsites at eight locations of the main-stem Chehalis River, southwestern Washington, 2015. Data are maximum temperatures (5-day rolling average) at each location. Horizontal dashed line at $21^{\circ} \mathrm{C}$ is added for reference. 

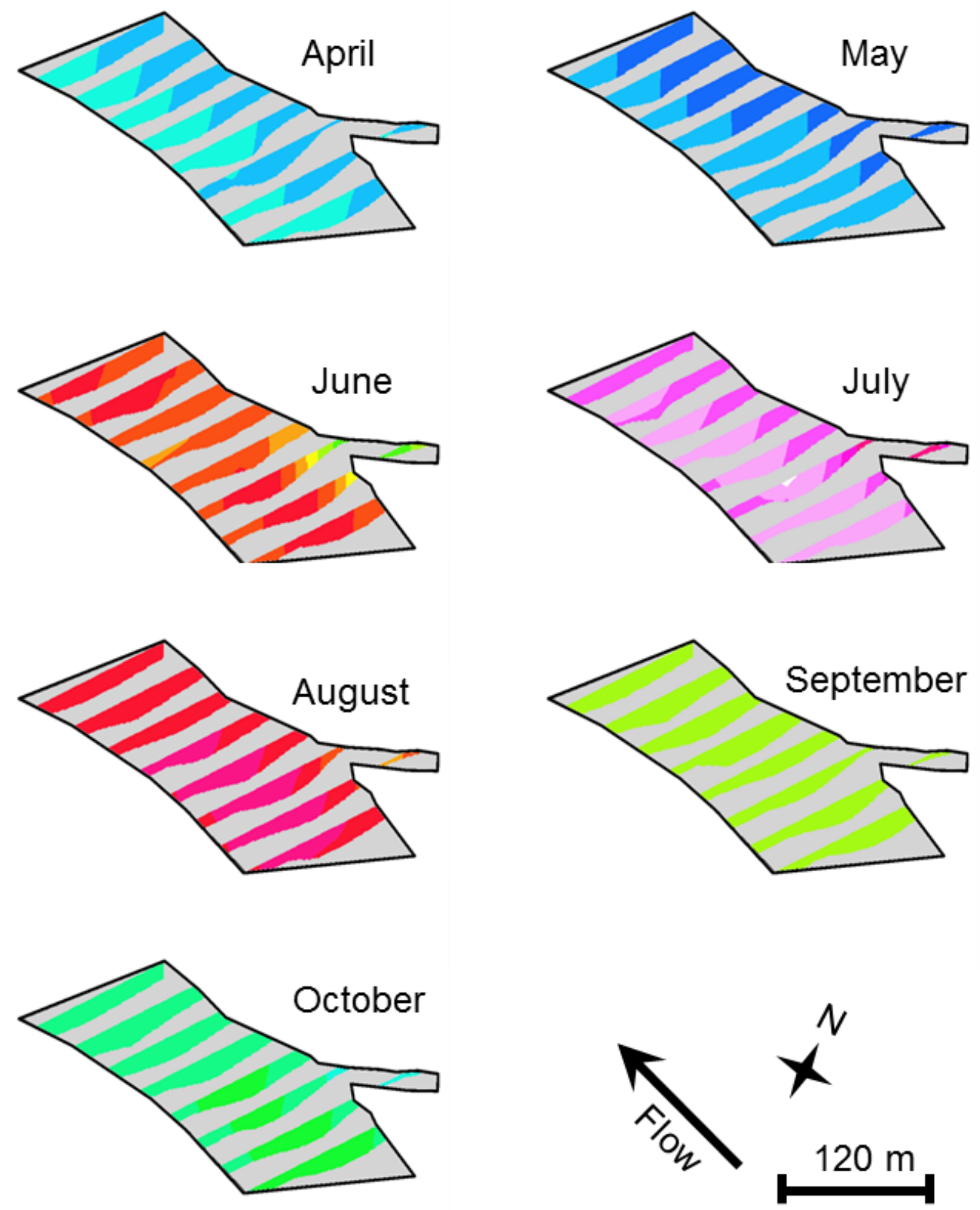

Temperature $\left({ }^{\circ} \mathrm{C}\right)$

12131415161718192021222324252627

Figure 7. Bathythermograph profiles of the Skookumchuck River confluence with the Chehalis River, southwestern Washington, April-October 2015. Water depth and water temperature data were collected using a series of transects and points (see fig. 2) and data were used to generate flood parts of the sampled area. Slices of the sampled area are shown with about 20 meters $(\mathrm{m})$ of separation. 

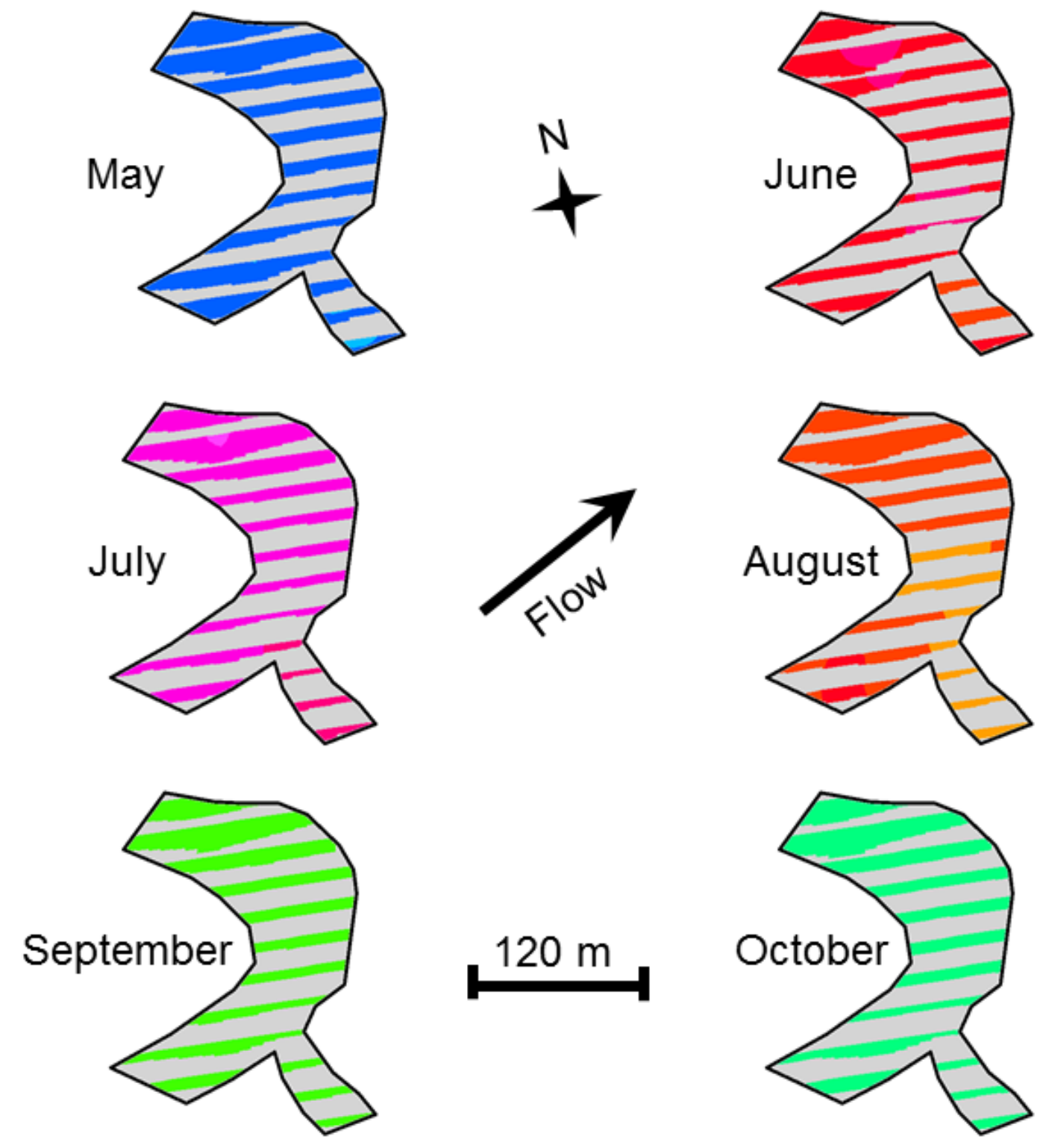

\section{Temperature $\left({ }^{\circ} \mathrm{C}\right)$}
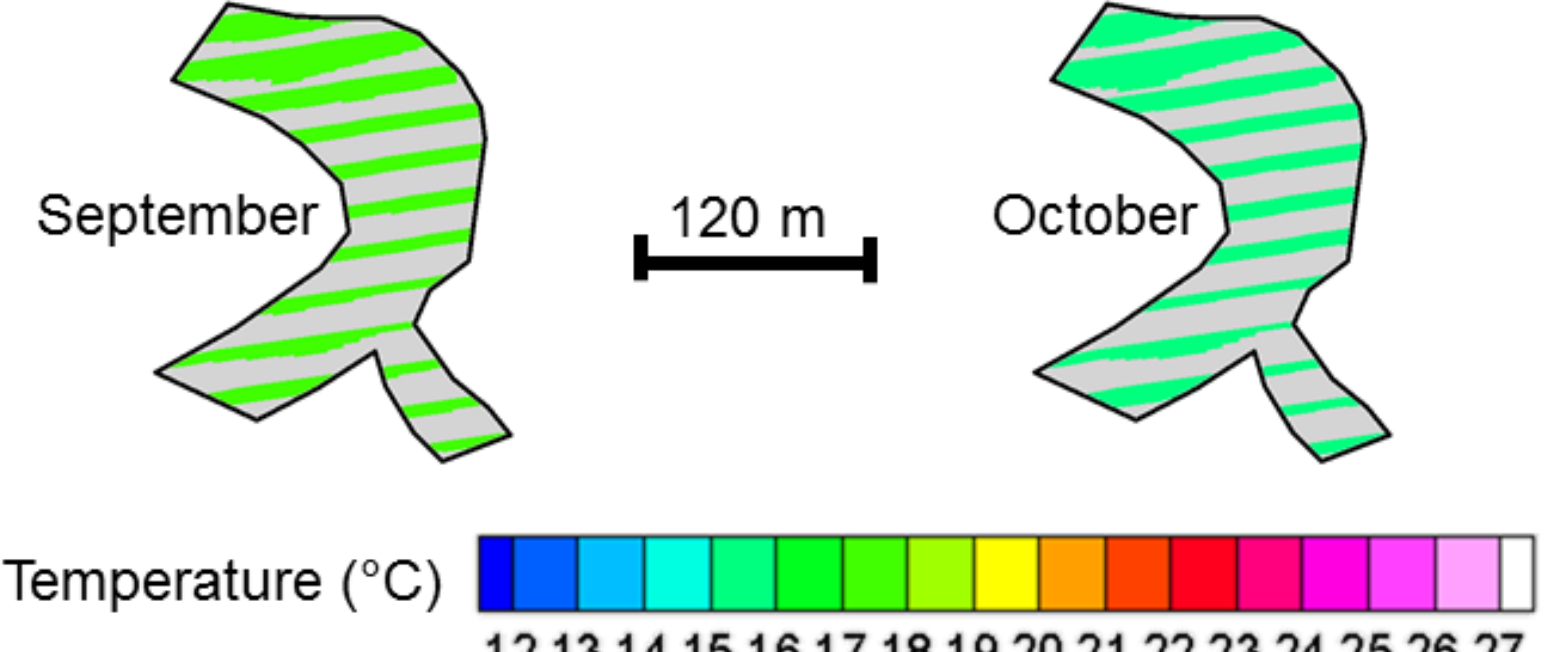

12131415161718192021222324252627

Figure 8. Bathythermograph profiles of the Newaukum River confluence with the Chehalis River, southwestern Washington, May-October 2015. Water depth and water temperature data were collected using a series of transects and points (see fig. 2) and data were used to generate flood plots of the sampled area. Slices of the sampled area are shown with about 20 meters $(\mathrm{m})$ of separation. 
The water temperatures in both tributaries generally were cooler than those of the Chehalis River, and during some BT surveys the influence of the tributary input on the Chehalis River was substantial. For example, at the Skookumchuck River, starting in May and continuing through July, the cooler water from the tributary can clearly be seen (fig. 7). Similarly at the Newaukum River, the largest influence of the tributary water can be seen in July and August (fig. 8). A detailed view of the June BT surveys (fig. 9) highlights the influence of tributary temperatures. During the early season and late season surveys, the differences between the Chehalis River and the tributaries appeared to be less, so the influence of the tributary was less obvious.

The lowest section of Skookumchuck River, at the confluence with the Chehalis River, provided access to deeper, cooler water for fish than the corresponding section of the Newaukum River. During the BT surveys (excluding April when only the Skookumchuck River was surveyed), the mean water depth at sampling points was $1.8 \mathrm{~m}$ at the Skookumchuck River compared to $1.4 \mathrm{~m}$ at the Newaukum River (table 4). The maximum water depth at both sites was similar, with close to $3 \mathrm{~m}$ of water available at both locations. Mean water depth available in mid-summer decreased somewhat at both sites (table 4), but there was no evidence of substantial stratification (figs. 7 and 8). Temperatures at both sites were most variable in June, and the peak temperatures were observed in July (table 4). The mean water temperature of the tributaries showed that the Skookumchuck River was $1{ }^{\circ} \mathrm{C}$ cooler, on average, than the Newaukum River (table 4). However, the mean water temperature in the Chehalis River near the tributary mouths was higher at the Skookumchuck River mouth $\left(19.7^{\circ} \mathrm{C}\right)$ than at the Newaukum River mouth $\left(19.1^{\circ} \mathrm{C}\right.$, table 4$)$.

During mid-summer, when water temperatures in the Chehalis River were highest, the temperatures in the tributaries were substantially cooler. The differences in water temperatures between the tributaries and the main-stem Chehalis River near the tributaries during June-August were from about 1 to greater than $5{ }^{\circ} \mathrm{C}$ (table 4). During the June BT survey at the Skookumchuck River, the difference in water temperature at several of the sampling sites was $5.8^{\circ} \mathrm{C}$. The largest difference observed in sampling sites at the Newaukum River was $2.9^{\circ} \mathrm{C}$, also in June. There were several months at both tributaries when water temperatures were similar with differences near zero (table 4).

There was sufficient water depth available in channels at both tributary mouths to allow spring Chinook salmon access throughout the study period. The Newaukum River mouth had consistent access from May to October with channels wide and deep enough to allow entry. Similarly, the Skookumchuck River had three channels available to fish throughout the study period. Both tributaries had areas of shallow water near the river mouth, but deeper water (more than $0.4 \mathrm{~m}$ ) was consistently available at both sites. 


\section{Skookumchuck River}

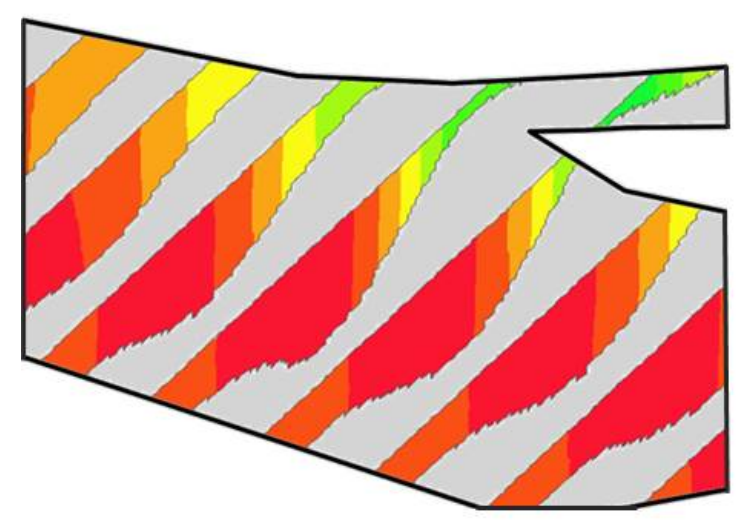

Newaukum River

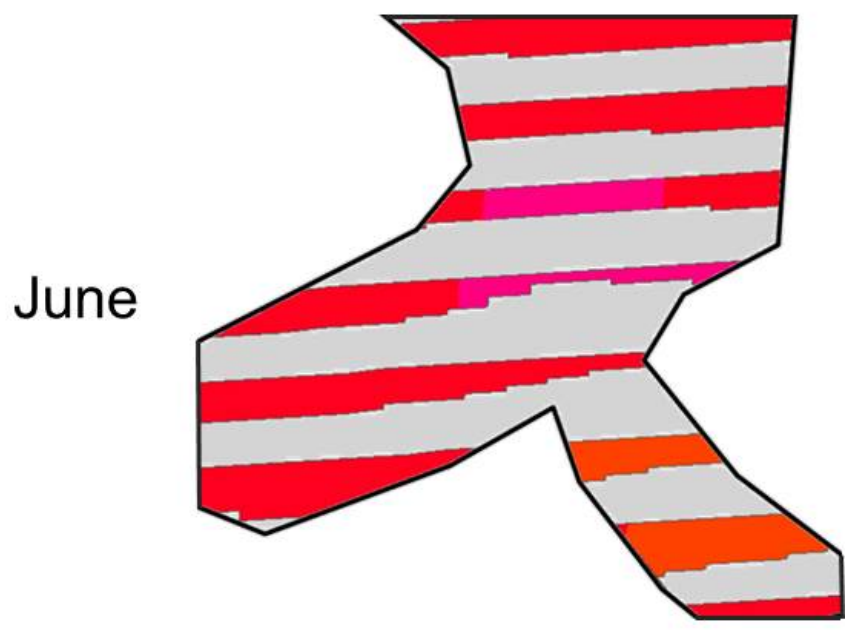

\section{Temperature, ${ }^{\circ} \mathrm{C}$}

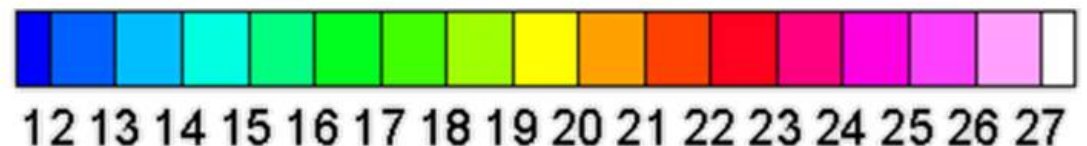

Figure 9. Bathythermograph profiles of the Skookumchuck and Newaukum Rivers at their confluences with the Chehalis River, southwestern Washington, June 2015. June profiles indicated in figures 7 and 8 were enlarged to show more clearly the influence of the tributary water on the main-stem Chehalis River.

\section{Spring Chinook Salmon Movements}

Overall, 22 of 23 tagged fish (96 percent) were detected either at the fixed sites or by mobile tracking (or both) after their release. The one fish that was not detected by either method was captured and released near RM 19 on the Chehalis River, downstream of the lowest fixed site (table 5). Mobile tracking efforts were conducted in the area, but the fish was never located. The mean number of days in the detection histories for tagged fish was $62 \mathrm{~d}$, and the fish with the longest detection history was tracked for $136 \mathrm{~d}$ (table 5). Mobile tracking teams, working throughout the study area, recovered 14 (61 percent) of the tags deployed for the study. Tag recoveries were high in this study for two primary reasons: (1) Tagged fish were monitored through the spawning period, allowing tags to be easily recovered from carcasses; and (2) mobile tracking teams worked to recover tags from fish that were removed from the river to aid in fate assignments. 
Fixed sites detected seven (64 percent) of the tagged fish released in the Chehalis River where the array was located. None of the tagged fish were detected at the fixed site highest in the Chehalis River Basin, at RM 91.0 near the town of Millburn, Washington. Additionally, no tagged fish were detected by the fixed site at RM 0.4 of the Skookumchuck River, suggesting that none of the study fish traveled substantial distances in the Skookumchuck River. The fixed site at Cedar Creek (RM 41.1) detected the highest proportion of tagged fish ( 5 fish, 45 percent). Four fixed sites each detected four tagged fish (36 percent): Eaton Creek (RM 31.4), Scatter Creek (RM 58.7), Lincoln Creek (RM 65.1), and the mouth of the Skookumchuck River (RM 69.8). On average, individual tagged fish released in the Chehalis River were detected by four fixed sites, and one fish was detected by eight fixed sites.

Mobile tracking efforts generated 165 fish detections, primarily from the Newaukum River subbasin (90 percent). Mobile tracking in the main-stem Chehalis River was conducted once per month from May to August 2015, in an effort to locate tagged fish that had not been detected by the fixed sites. Throughout the summer, however, mobile tracking efforts focused on the Newaukum River subbasin in response to the entry of tagged fish from the main-stem river (based on fixed-site detections) and the presence of fish tagged and released in the South Fork Newaukum River. Weekly tracking efforts in the Newaukum River began during the week of June 22, 2015, and continued through the week of October 12, 2015. For each 2-week period, 79-100 percent of all tagged fish present in the Newaukum River were detected by mobile tracking. Overall, mobile tracking efforts detected all tagged fish in the Newaukum River. Six tagged fish (50 percent) had about $100 \mathrm{~d}$ of detections, from the time of release to the end of the study period. The mean number of mobile tracking detections per fish was 7 , with a minimum of zero and a maximum of 19 detections on individual fish (table 5).

Based on the review of the detection histories and, in some cases, the ability to recover the transmitters implanted in study fish, each fish was assigned a fate. Overall, eight tagged fish (35 percent) were assigned a fate of spawner based on detections of these fish in spawning areas during the spawning period (table 5). Eight other tagged fish (35 percent) were assigned a fate of pre-spawn mortality (table 5). Four fish (17 percent) showed limited movement after release and were estimated to have either died or regurgitated their transmitter (spit/mortality fate). The final three fish (13 percent) had unknown fates (table 5). 
Table 5. Statistics for all radio-tagged spring Chinook salmon monitored during study period, Chehalis River Basin, southwestern Washington, 2015.

[Details include Tag ID, fish number, study area (main-stem Chehalis River [MC] or South Fork Newaukum River [SFN]), capture gear used hook/line [HL] or tangle net [TN]), release location (river miles from the river mouth), release date, fork length (FL), sex, number of fixed sites that detected fish, number of times fish was detected by mobile tracking, last known location (NFN, North Fork Newaukum River) and last date of detection, number of days in detection history of fish (last date of detection/date of release), and fate assigned to fish based on detection history. NA, not applicable]

\begin{tabular}{|c|c|c|c|c|c|c|c|c|c|c|c|c|c|}
\hline Tag ID & $\begin{array}{c}\text { Fish } \\
\text { no. }\end{array}$ & $\begin{array}{l}\text { Study } \\
\text { area }\end{array}$ & Gear & $\begin{array}{c}\text { Release } \\
\text { location } \\
\text { (river mile) }\end{array}$ & $\begin{array}{c}\text { Release } \\
\text { date }\end{array}$ & $\begin{array}{c}\text { FL } \\
\text { (centi- } \\
\text { meters) }\end{array}$ & Sex & $\begin{array}{c}\text { Fixed-site } \\
\text { summary } \\
\text { (number of } \\
\text { sites } \\
\text { detected) }\end{array}$ & $\begin{array}{c}\text { Mobile } \\
\text { tracking } \\
\text { summary } \\
\text { (number of } \\
\text { detections) }\end{array}$ & $\begin{array}{l}\text { Last known } \\
\text { location }\end{array}$ & $\begin{array}{l}\text { Late date } \\
\text { detected }\end{array}$ & $\begin{array}{l}\text { Days in } \\
\text { detection } \\
\text { history }\end{array}$ & Fate \\
\hline 40003 & 1 & $\mathrm{MC}$ & HL & 28 & $4-27$ & 80 & $\mathrm{M}$ & 0 & 3 & Release site & $5-28$ & 31 & Spit/mortality \\
\hline 40039 & 2 & $\mathrm{MC}$ & HL & 28 & $4-27$ & 65 & $\mathrm{~F}$ & 0 & 6 & Release site & $5-28$ & 31 & $\begin{array}{l}\text { Pre-spawn } \\
\text { mortality }\end{array}$ \\
\hline 40014 & 3 & $\mathrm{MC}$ & HL & 19 & $6-16$ & 85 & $\mathrm{~F}$ & 0 & 0 & Release site & NA & 0 & Unknown \\
\hline 40016 & 4 & $\mathrm{MC}$ & HL & 19.9 & $6-17$ & 82.5 & $\mathrm{~F}$ & 0 & 2 & Release site & $7-16$ & 29 & Spit/mortality \\
\hline 14011 & 5 & $\mathrm{MC}$ & $\mathrm{TN}$ & 46.7 & $6-22$ & 75 & $\mathrm{~F}$ & 3 & 4 & $\begin{array}{l}\text { Skookumchuck } \\
\text { Mouth }\end{array}$ & $10-12$ & 112 & Spawner \\
\hline 40041 & 6 & $\mathrm{MC}$ & HL & 43.6 & $5-15$ & 74 & $\mathrm{~F}$ & 6 & 14 & NFN & $9-17$ & 125 & $\begin{array}{l}\text { Pre-spawn } \\
\text { mortality }\end{array}$ \\
\hline 40037 & 7 & $\mathrm{MC}$ & HL & 37.1 & $5-15$ & 62 & M & 7 & 16 & NFN & $9-28$ & 136 & Spawner \\
\hline 40024 & 8 & $\mathrm{MC}$ & HL & 19.9 & $6-17$ & 78 & M & 2 & 4 & Cedar Creek & $8-19$ & 63 & $\begin{array}{l}\text { Pre-spawn } \\
\text { mortality }\end{array}$ \\
\hline 40034 & 9 & $\mathrm{MC}$ & $\mathrm{HL}$ & 19.9 & $6-16$ & 80 & $\mathrm{~F}$ & 2 & 0 & Cedar Creek & $6-23$ & 7 & Unknown \\
\hline 40043 & 10 & $\mathrm{MC}$ & $\mathrm{HL}$ & 19.9 & $6-25$ & 78 & $\mathrm{~F}$ & 2 & 0 & Cedar Creek & $6-30$ & 5 & Unknown \\
\hline 40042 & 11 & $\mathrm{MC}$ & HL & 19.9 & $6-22$ & 76.5 & $\mathrm{~F}$ & 8 & 2 & Newaukum & $10-13$ & 113 & Spawner \\
\hline 40019 & 12 & SFN & $\mathrm{TN}$ & 10.6 & $6-11$ & 70.5 & $\mathrm{~F}$ & 0 & 19 & SFN & $10-13$ & 124 & Spit/mortality \\
\hline 40020 & 13 & SFN & $\mathrm{TN}$ & 11.2 & $6-11$ & 62 & M & 0 & 9 & SFN & $8-4$ & 54 & $\begin{array}{l}\text { Pre-spawn } \\
\text { mortality }\end{array}$ \\
\hline 40012 & 14 & SFN & $\mathrm{TN}$ & 11.2 & $6-15$ & 67.5 & M & 0 & 18 & SFN & $9-28$ & 105 & Spawner \\
\hline 40038 & 15 & SFN & HL & 11.2 & $6-15$ & 66.5 & $\mathrm{~F}$ & 0 & 12 & SFN & $9-24$ & 101 & Spawner \\
\hline 40025 & 16 & SFN & $\mathrm{TN}$ & 9.3 & $6-18$ & 78 & $\mathrm{~F}$ & 0 & 3 & SFN & $7-1$ & 13 & Spit/mortality \\
\hline 40027 & 17 & SFN & $\mathrm{TN}$ & 9.3 & $6-18$ & 75 & $\mathrm{~F}$ & 0 & 13 & SFN & $10-1$ & 105 & Spawner \\
\hline 40029 & 18 & SFN & $\mathrm{TN}$ & 9.3 & $6-18$ & 63 & $\mathrm{~F}$ & 0 & 12 & SFN & $10-8$ & 112 & Spawner \\
\hline
\end{tabular}




\begin{tabular}{|c|c|c|c|c|c|c|c|c|c|c|c|c|c|}
\hline Tag ID & $\begin{array}{c}\text { Fish } \\
\text { no. }\end{array}$ & $\begin{array}{l}\text { Study } \\
\text { area }\end{array}$ & Gear & $\begin{array}{c}\text { Release } \\
\text { location } \\
\text { (river mile) }\end{array}$ & $\begin{array}{c}\text { Release } \\
\text { date }\end{array}$ & $\begin{array}{c}\text { FL } \\
\text { (centi- } \\
\text { meters) }\end{array}$ & Sex & $\begin{array}{c}\text { Fixed-site } \\
\text { summary } \\
\text { (number of } \\
\text { sites } \\
\text { detected) }\end{array}$ & $\begin{array}{l}\text { Mobile } \\
\text { tracking } \\
\text { summary } \\
\text { (number of } \\
\text { detections) }\end{array}$ & $\begin{array}{l}\text { Last known } \\
\text { location }\end{array}$ & $\begin{array}{l}\text { Late date } \\
\text { detected }\end{array}$ & $\begin{array}{l}\text { Days in } \\
\text { detection } \\
\text { history }\end{array}$ & Fate \\
\hline 40039 & 19 & SFN & TN & 9.3 & $6-18$ & 75 & $\mathrm{M}$ & 0 & 15 & SFN & $9-24$ & 98 & Spawner \\
\hline 40044 & 20 & SFN & $\mathrm{TN}$ & 9.2 & $7-1$ & 73 & F & 0 & 5 & SFN & $7-21$ & 20 & $\begin{array}{l}\text { Pre-spawn } \\
\text { mortality }\end{array}$ \\
\hline 14021 & 21 & SFN & $\mathrm{TN}$ & 11.2 & $7-1$ & 84.5 & F & 0 & 2 & SFN & $7-7$ & 6 & $\begin{array}{l}\text { Pre-spawn } \\
\text { mortality }\end{array}$ \\
\hline 14020 & 22 & SFN & $\mathrm{TN}$ & 11.2 & $7-1$ & 76 & M & 0 & 4 & SFN & $7-20$ & 19 & $\begin{array}{l}\text { Pre-spawn } \\
\text { mortality }\end{array}$ \\
\hline 14022 & 23 & SFN & $\mathrm{TN}$ & 11.2 & $7-1$ & 84.5 & $\mathrm{~F}$ & 0 & 2 & SFN & $7-9$ & 8 & $\begin{array}{c}\text { Pre-spawn } \\
\text { mortality }\end{array}$ \\
\hline
\end{tabular}




\section{Main-Stem Chehalis River Fish}

Seven (64 percent) of the radio-tagged spring Chinook salmon captured and released in the main-stem Chehalis River moved upstream following release (table 6). Three of these seven fish moved upstream within a week of release (2-7 d), three fish were first detected upstream 12-18 d after release, and one fish stayed near the release location for $64 \mathrm{~d}$ before moving upstream (table 6). With few exceptions, tagged fish moved upstream past the array of fixed sites quickly, being detected at each site briefly before moving upstream to the next fixed site (fig. 10). The longest residence time for a fish at a fixed site was for fish 11, which was detected at the mouth of the Newaukum River for $14 \mathrm{~d}$. With this one exception, the mean residence time for fish at fixed sites ranged between $7.2 \mathrm{~min}$ and $6.6 \mathrm{~h}$. The mean migration rates through various reaches in the main-stem Chehalis River, based on fixed-site detections, ranged from 8.7 to $18.5 \mathrm{mi} / \mathrm{d}$ (fig. 11). The mean maximum displacement for these seven fish, calculated as total river miles from the release location to the farthest point away from the release location, was 37.5 river miles (minimum 21.2 river miles, maximum 63.3 river miles).

Table 6. Timing of first date of detection on fixed-location telemetry monitoring sites (fixed sites) for radio-tagged spring Chinook salmon captured and released in Chehalis River Basin, southwestern Washington, 2015.

[Release locations for fish are shown in rows with gray shading. Locations of fixed sites are shown as river miles (RMs) on main-stem Chehalis River and are described in table 1. Details of the capture, release, and size of tagged fish are described by fish number in table 5]

\begin{tabular}{|c|c|c|c|c|c|c|c|c|}
\hline \multirow{2}{*}{ Fixed site location } & \multicolumn{8}{|c|}{ Fish number } \\
\hline & $1-4$ & 5 & 6 & 7 & 8 & 9 & 10 & 11 \\
\hline Release & $\begin{array}{c}\text { April } 27(2) \\
\text { June } 16 \\
\text { June } 17\end{array}$ & & & & June 17 & June 16 & June 25 & June 22 \\
\hline RM 31.4 & & & & & June 19 & June 23 & June 29 & August 25 \\
\hline Release & & & & May 15 & & & & \\
\hline RM 41.1 & & & & May 27 & June 20 & June 23 & June 30 & August 30 \\
\hline Release & & June 22 & May 15 & & & & & \\
\hline RM 58.7 & & July 10 & May 30 & May 29 & & & & August 31 \\
\hline RM 65.1 & & September 2 & May 31 & May 30 & & & & August 31 \\
\hline RM 69.8 & & September 5 & June 1 & May 30 & & & & September 1 \\
\hline $\begin{array}{l}\text { RM } 70.4 \\
\text { Skookumchuck } \\
\text { River }\end{array}$ & & & & & & & & \\
\hline RM 74.8 & & & June 1 & June 2 & & & & September 1 \\
\hline RM 78.7 & & & June 2 & June 2 & & & & September 1 \\
\hline $\begin{array}{l}\text { RM } 80.3 \\
\quad \text { Newaukum } \\
\text { River }\end{array}$ & & & June 6 & June 3 & & & & September 28 \\
\hline RM 91.0 & & & & & & & & \\
\hline
\end{tabular}




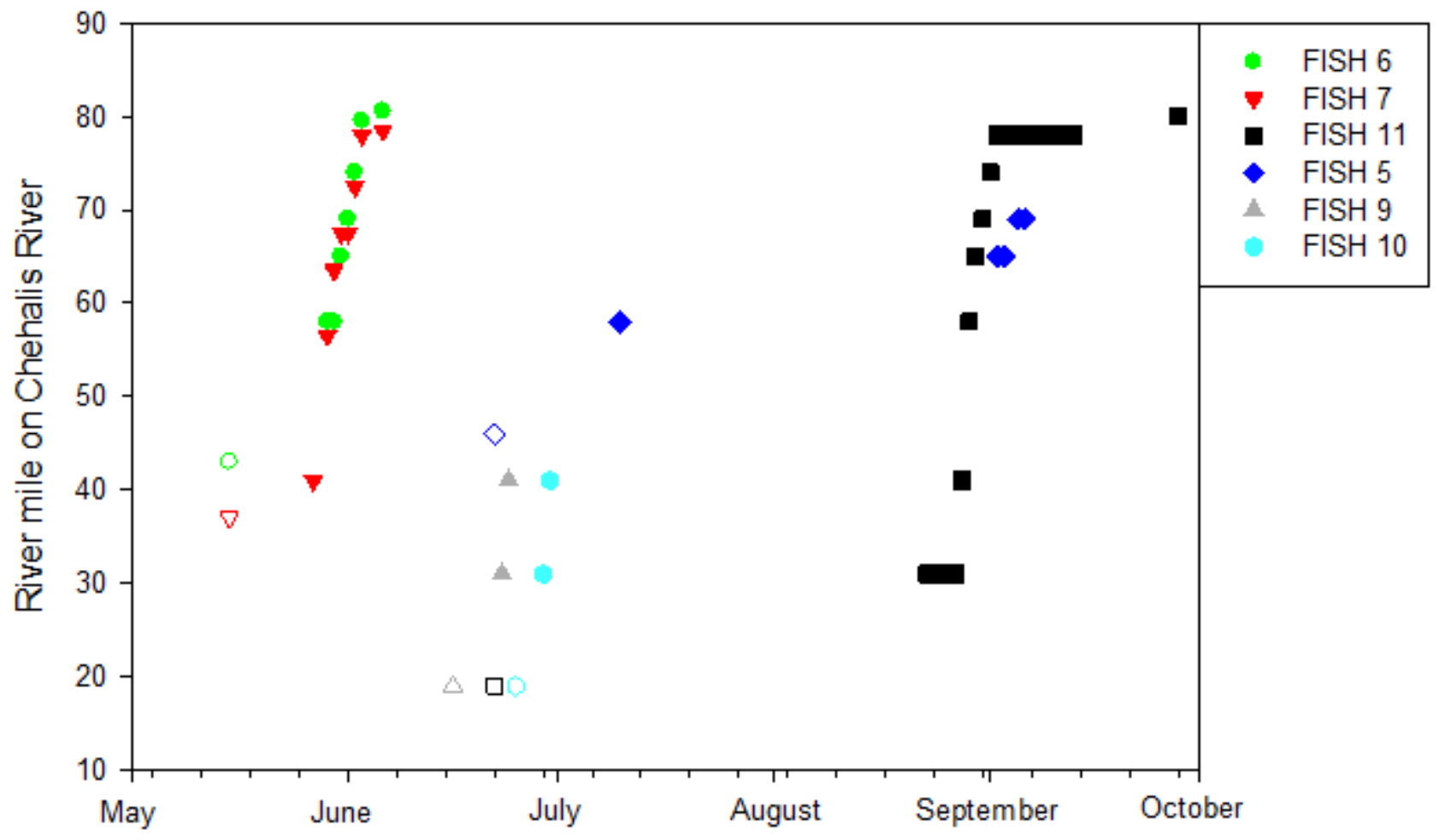

Figure 10. Graph showing timing of movements for six radio-tagged spring Chinook salmon, Chehalis River Basin, southwestern Washington, May-October 2015. Tagged fish were detected at fixed monitoring locations along the Chehalis River (see table 1 for river mile location of fixed sites) as they moved upstream toward spawning areas. For each fish, filled shapes show dates and locations (by river mile) of fixed-site detections, and open shapes show location (by river mile) and date of release. Fish numbers indicated in the figure correspond to the fish numbers shown in table 5. 


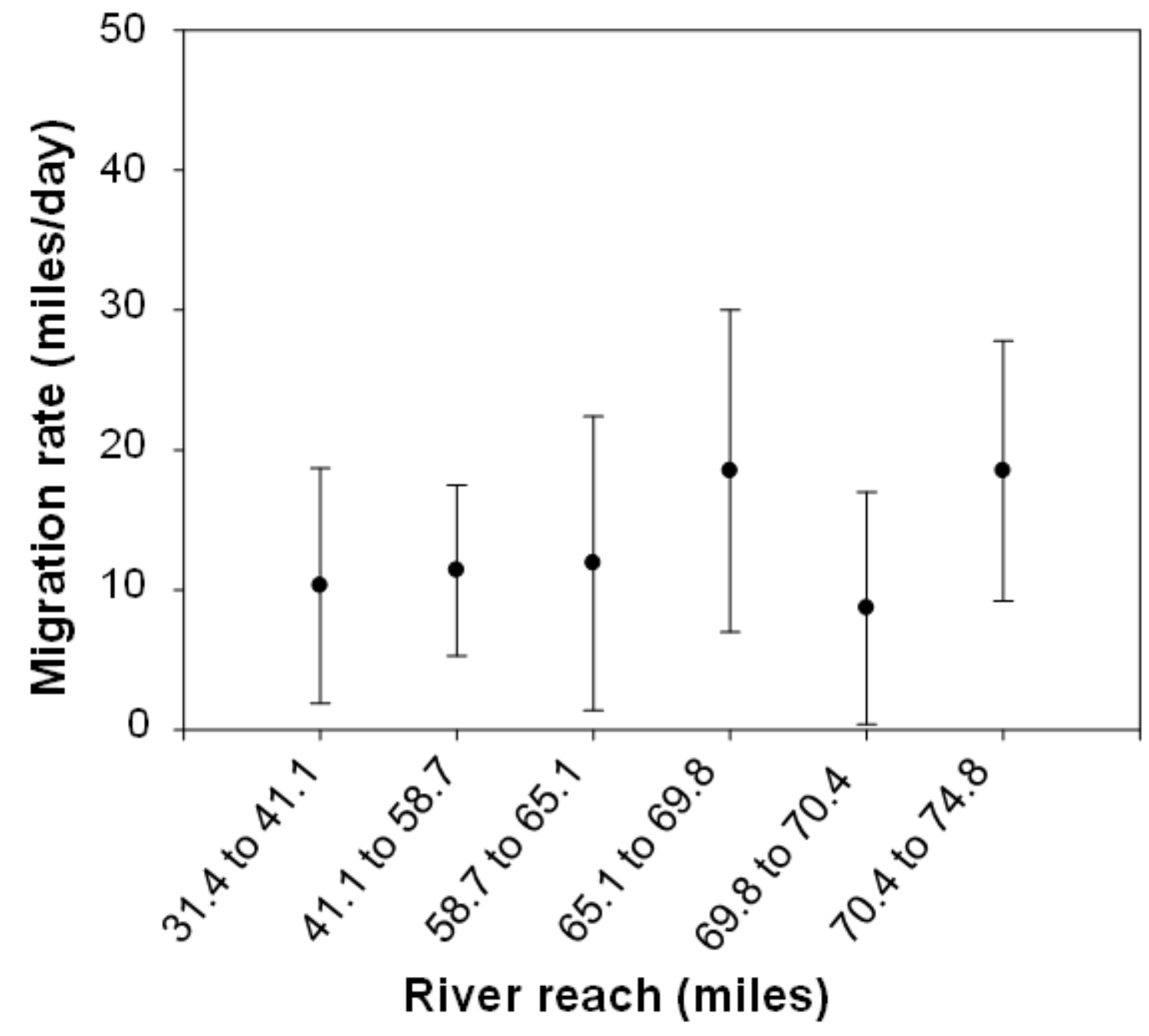

Figure 11. Graph showing mean migration rates (in miles per day) for radio-tagged spring Chinook salmon, mainstem Chehalis River, southwestern Washington, 2015. River reaches (by river mile) represent reaches between locations of fixed sites described in table 1. Bars represent 1 standard deviation from the mean. 
The final fates for the seven fish that moved upstream following release included two fish with unknown fates, two fish with a fate of pre-spawn mortality, and three fish that were assigned a fate of spawner (table 5). The two fish (fish 9 and fish 10) with unknown fates had short detection histories of 5-7 d and were last detected by the fixed site at Cedar Creek within 1 week of their release dates in June 2015. There were no further detections of these fish despite mobile tracking efforts in the area. The two fish (fish 6 and fish 8) assigned a fate of pre-spawn mortality were last detected in the North Fork Newaukum River and at Cedar Creek. Fish 8, last detected at Cedar Creek, likely was either eaten by a predator or harvested as the tag was recovered in tall grass on the river bank on August 19, 2015 (table 5). Finally, the three fish with a fate of spawner were last detected at the mouth of the Skookumchuck River (fish 5), and in the Newaukum River (fish 7 and fish 11). One of these fish, fish 11, was confirmed to have spawned as the tag was recovered near a group of redds in the main-stem Newaukum River, downstream of the confluence of the north and south forks, on October 13, 2015. Fish 7 was not confirmed to have spawned, but survived to the spawning period, had the longest detection history of any of the study fish (136 d), and had the highest maximum displacement from the release site. The final location for fish 7 was 10 river miles upstream of the mouth of the North Fork Newaukum River at the end of September (table 5), having moved 63.3 river miles from the release site. As a group, the three fish with a fate of spawner had a mean maximum displacement of 48.9 river miles from their release sites (minimum 23.1 river miles, maximum 63.3 river miles).

Four (36 percent) of the radio-tagged Chinook salmon captured and released in the main-stem Chehalis River showed limited movement from their release sites. These fish (fish 1-4) were all captured and released downstream of the lowest fixed site (RM 31.4) and never moved upstream far enough to be detected by any of the fixed sites (table 6). Mobile tracking conducted downstream of the lowest fixed site to the Satsop River confluence during June-August 2015, provided a few detections for three of these fish (fish 1, 2, and 3), but did not document any substantial movement from their release sites (table 5). The fates assigned to these four fish included one unknown, one pre-spawn mortality, and two spit/mortality fates (table 5). The unknown fate (fish 3) was never detected by fixed sites or mobile tracking. Fish 2 was assigned a pre-spawn mortality fate as the tag was recovered May 28,2015 , well above the high water mark on the river bank, near the release location. Based on the tag recovery location, it appears that this fish was either consumed by a predator or was harvested. Two fish (fish 1 and fish 4) were assumed to have either died or regurgitated their tags near their release location. Mobile tracking efforts were able to visualize the bottom of the river at the location of one tag (fish 1) and no fish or fish activity was observed. The other tag (fish 4) was located twice in the area of a log jam.

\section{South Fork Newaukum River Fish}

Spring Chinook salmon that were captured and released in the South Fork Newaukum River remained in the South Fork Newaukum River throughout the study period. The sites where fish were captured and released were between RMs 9.2 and 11.2 on the South Fork Newaukum River, substantially upstream (19.4-21.4 river miles) of the nearest fixed site at the mouth of the Newaukum River (fig. 1). None of the 12 tagged fish released in the South Fork Newaukum River were detected on any fixed site, but their movements were monitored through regular mobile tracking efforts. 
Tagged spring Chinook salmon remained in a limited area of the North Fork and South Fork Newaukum Rivers during the study period. The entire known distribution for spring Chinook salmon in the Newaukum River subbasin includes the main-stem Newaukum River (11.8 river miles upstream of the confluence with the Chehalis River), the North Fork Newaukum River (13.4 river miles upstream of the confluence with the South Fork and 25.2 river miles upstream of the Newaukum River confluence with main-stem Chehalis River), and the South Fork Newaukum River (18.5 river miles upstream of the confluence with the North Fork and 30.3 river miles upstream of the Newaukum River confluence with main-stem Chehalis River; Washington Department of Fish and Wildlife, 2016). However, during the entire 2015 study period, the tagged fish were detected within just a 9-river mile reach in the South Fork Newaukum River, from RMs 5.4 to 14.6 (30 percent of documented range; fig. 12). The mean maximum displacement for fish in the South Fork Newaukum River was 3 river miles from the release site (minimum 1.2 river miles, maximum 4.3 river miles). Fish in the North Fork Newaukum River (fish 6 and fish 7) were detected entering the tributary from the Chehalis River where they were tagged and released, moved upstream rapidly, and were detected within a 5-river mile reach in the North Fork Newaukum River, from RMs 5.2 to 9.9 (25 percent of documented range; fig. 12). Fish 11, also tagged and released in the Chehalis River, entered the main-stem Newaukum River and remained downstream of the north and south forks through the end of the study.
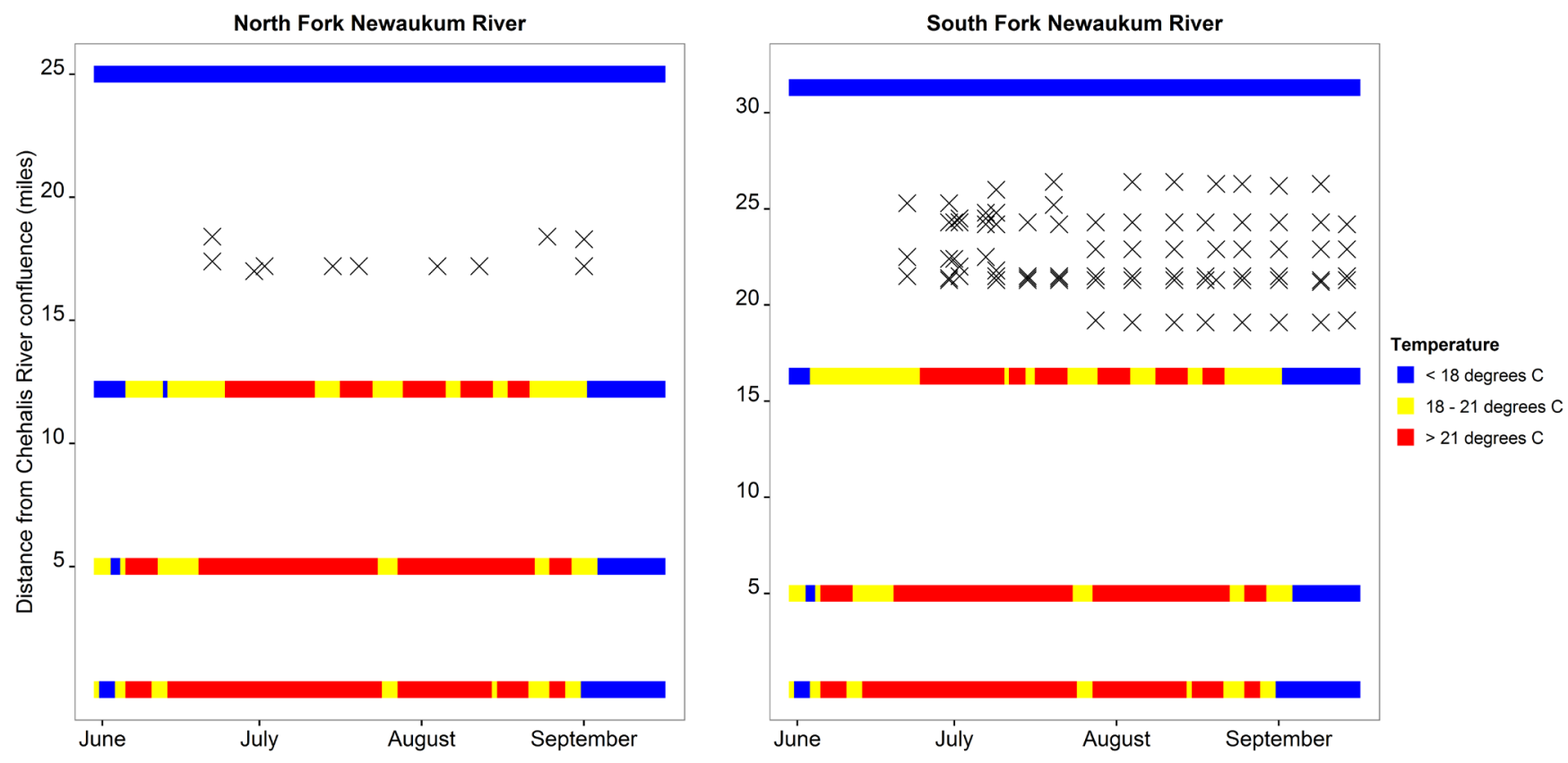

Figure 12. Graphs showing locations of spring Chinook salmon in North Fork and South Fork Newaukum River, southwestern Washington. "X" indicates the locations where radio-tagged fish were detected by mobile tracking during weekly surveys. Filled squares represent the locations of in-stream temperature loggers. Color of each square indicates average daily temperatures. r. Scale of the $Y$-axis represents the upper extent of documented spring Chinook salmon spawning. Confluence of north and south forks of Newaukum River occurs at river mile 11. 
Five (42 percent) of the radio-tagged spring Chinook salmon captured and released in the South Fork Newaukum River were actively moving and were tracked through the spawning period in September 2015. All five fish were assigned a fate of spawner, and four of the five fish were confirmed to have spawned in the South Fork Newaukum River. These fish showed two general pulses of movement. Movements occurred in upstream and downstream directions immediately following release in June and early July 2015. Following these movements, fish were detected at relatively consistent locations throughout the remainder of summer. A second pulse of movement occurred in September or early October when the tagged fish moved again (both upstream and downstream to spawning locations. Fish 14 was regularly detected in a deep pool $60 \mathrm{~m}$ downstream of the release point between late June and mid-September. In mid-September, the fish moved downstream 3.7 river miles and was observed to be spawning. Fish 15 was regularly detected 1 river mile upstream of the release point between late June and mid-September. In mid-September, the fish moved 6.3 river miles downstream where the tag was recovered near a redd. Fish 17 was detected progressively farther downstream from its release location through late July. Between late July and late September, the fish was regularly detected 3.6 river miles downstream of its release location. In late September, the fish moved an additional 2 river miles downstream and the tag was recovered near a redd and several carcasses. Fish 18 was regularly detected 0.4 river miles upstream of the release point between late July and early October (no detections between mid-June release and late July). In early October, the fish moved an additional 2.2 river miles upstream. Fish 19 was regularly detected in a hole just downstream of the release point between late June and midSeptember. In late September, the tag was recovered at this same location near a redd at the top of a riffle.

Seven (58 percent) of the radio-tagged spring Chinook salmon captured and released in the South Fork Newaukum River were detected for a period following release, but their detection histories ended prior to the spawning period. The fates assigned to these seven fish included two fish with spit/mortality fates and five fish with fates of pre-spawn mortality (table 5). Of the two spit/mortality fates, one fish (fish 16) was a confirmed mortality on July 1, 2015, and the other fish (fish 12) was detected throughout the study period in a log jam. All five fish assigned a fate of pre-spawn mortality showed evidence that the tag was removed from the water by either a predator or an angler, and two fish were confirmed to have been harvested. Tags were recovered from six of the tagged fish (all except fish 12).

\section{Spring Chinook Salmon and Water Temperatures}

Summaries of Chinook salmon and water temperature were based on fixed gear and mobile tracking detections of tagged fish, combined with the water temperature data collected by the array of stream temperature loggers. Fixed-site detections of tag temperature sensors had the potential to generate large datasets of fish temperature selection as the sensor emitted a temperature reading several times each minute. Temperature datasets, however, were relatively small because of limited detections and short residence times of tagged fish near the fixed sites. Tag sensor data collected by the fixed sites was most abundant during early and later summer. Few records of fish temperature selection were available in June and July because few fish were detected at the fixed sites during this period (table 7). Only five individual tagged fish had tag sensor data collected by the fixed sites, and three fish had few records. The fixed site at Cedar Creek (RM 41.1) had the highest number of detections of tag sensors, with temperature data available for four consecutive months (table 7). Each mobile tracking detection provided a tag sensor reading, and there were 28 mobile tracking detections that were used to evaluate temperature effects. Most records were from the Newaukum River, in July (46 percent) and August (26 percent). 
Table 7. Mean selected water temperatures based on transmitter temperature sensor readings for radio-tagged spring Chinook salmon detected by fixed-site telemetry monitoring stations (fixed sites) in Chehalis River, southwestern Washington, 2015.

[The transmitter temperature sensor readings (in degrees Celsius) for all tagged fish detected by fixed site in each month were averaged and are presented by fixed site and month. Standard deviation of mean is indicated in parentheses. Locations of fixed sites are shown as river miles (RMs) on main-stem Chehalis River and are described in table 1, NA, not applicable]

\begin{tabular}{llllll}
\hline Fixed site & \multicolumn{1}{c}{ May } & \multicolumn{1}{c}{ June } & \multicolumn{1}{c}{ July } & \multicolumn{1}{c}{ August } & September \\
\hline RM 31.4 & NA & $22.1( \pm 0.5)$ & NA & $20.8( \pm 0.6)$ & NA \\
RM 41.1 & $16.5( \pm 0.3)$ & $19.9( \pm 0.8)$ & $20.2(0.8)$ & $18.8( \pm 0.2)$ & NA \\
RM 58.7 & $19.9( \pm 0.2)$ & NA & NA & $20.4( \pm 0.4)$ & NA \\
RM 65.1 & $20.5( \pm 0.4)$ & NA & NA & $20.6( \pm 0.6)$ & NA \\
RM 69.8 & $19.7( \pm 0.8)$ & $19.7( \pm 0.3)$ & NA & NA & $20.3( \pm 0.5)$ \\
RM 74.8 & $19.5( \pm 0.6)$ & NA & NA & NA & $18.8( \pm 0.9)$ \\
RM 78.7 & $17.9( \pm 0.4)$ & NA & NA & NA & $18.6( \pm 0.4)$ \\
RM 80.3 & $19.1( \pm 0.3)$ & NA & NA & NA & $14.0( \pm 0.3)$ \\
\hline
\end{tabular}

\section{Questionable Performance of Tag Temperature Sensors}

During the active phase of the study when tagged fish were being monitored, mobile tracking crews reported that several tags appeared to have malfunctioning temperature sensors. The temperature reported by the tag sensor did not match well with what could be measured for ambient water temperature near the fish or what generally was known about then-current water temperature conditions in the Chehalis River Basin. Several of these questionable tags were recovered from tagged fish (following a predation/harvest event or spawning) and were used to conduct controlled testing of the sensor compared to known water temperatures. The detailed methods and results of the post-season sensor testing are reported in appendix A. Three recovered tags were tested at three test water temperatures: 0,19 , and $34^{\circ} \mathrm{C}$. These test temperatures were selected to represent the range of temperatures observed in the study and to test the specified range of capability of the sensor.

Post-season testing of the recovered tags indicated that the tag sensors performed poorly at the highest water temperature tested. None of the three tags had reliable performance at $34{ }^{\circ} \mathrm{C}$, but the tags performed adequately at the lower two test temperatures (appendix A). All tags with questionable performance and all tags recovered and tested during post-season sensor testing were from the collection of tags purchased in 2014. These tags had been stored for 1 year following their manufacture, and in some cases had been used previously in fish. For example, tag ID 40039 had been used to tag a fish in 2014, had an unknown expenditure of battery life, and was recovered and stored until the start of the 2015 study. There were no reports of questionable performance for any 2015 tags deployed for the study. None of the recovered tags were included in the pre-season sensor testing. Tags with questionable performance were excluded from analyses of temperature selection by fish.

\section{Movement Timing}

The timing of the movements of spring Chinook salmon released in the Chehalis River appeared to be related to water temperatures. Fish primarily moved upstream prior to or after water temperatures peaked during July and August. No substantial fish movements (that is, moving between fixed sites) were detected between mid-July and the end of August (fig. 10). Five (71 percent) of the seven fish detected by fixed sites moved upstream prior to the maximum water temperatures in July, one fish moved upstream in early July and then stopped moving until early September, and one fish did not show any substantial movement from the release site until late August (table 6). The five fish that moved 
upstream in early summer began moving shortly after release and had arrived at their farthest upstream detection location before July. The timing of capture and release did not appear to influence the timing of the upstream movements. Two of the five fish were released in mid-May, two in mid-June, and one in late June (table 6). Fish 11 showed a late-summer movement pattern, staying near the release site low in the Chehalis River until late August and then quickly moving upstream to the Newaukum River by the end of September (table 6, fig. 10). Fish 5 showed a mixed timing pattern for upstream movements. Fish 5 was first detected by a fixed site about $20 \mathrm{~d}$ after release, on July 10, but no further movements were detected until September 2 when the fish began moving substantial distances upstream (table 6).

Consistent with observations from the main-stem river, spring Chinook salmon released in the South Fork Newaukum River had minimal movements during summer, especially during August. These fish had already completed a substantial part of their upstream migration prior to tagging, so movements later in summer were relatively small compared to movements detected in the main-stem Chehalis River. Tagged fish that survived to September and October moved upstream and downstream from their summer holding locations 1 or 2 weeks prior to spawning. Fish 14 moved 3.7 river miles downstream between mid- and late September after being detected at the same location since July 1, 2015. Fish 15 moved 6.3 river miles downstream in mid-September after being detected at the same location since July 20, 2015. Fish 17 moved 2.0 river miles downstream in late September after being detected in the same location since July 28, 2015. Fish 18 moved 2.2 river miles upstream in early October after being detected in the same location since July 28, 2015. Fish 19 spawned in a riffle just upstream of its summer holding location after being detected in the same location since July 9, 2015.

\section{Site Selection}

Tagged fish were not frequently detected at sites where water temperatures were greater than 21 ${ }^{\circ} \mathrm{C}$. The mean tag sensor temperature for fish detected by each fixed site for each month of the study period was greater than $21^{\circ} \mathrm{C}$ in only one instance (table 7). The fixed site at RM 31.4, the lowest site in the Chehalis River detected a fish with a mean sensor temperature of $22.1{ }^{\circ} \mathrm{C}$ during July, representing 5 percent of the total observations summarized (table 7). Fish detected by mobile tracking in the South Fork Newaukum River during July-September (26 observations) did not have any tag sensor readings greater than $21{ }^{\circ} \mathrm{C}$. The highest mean tag sensor temperature was in July, at $19.1{ }^{\circ} \mathrm{C}$. The ambient river temperature, recorded by temperature loggers near the fish locations, is another way to examine fish temperature selection. This approach is especially useful to support mobile tracking detections because only a single tag sensor reading is generated for each fish detection. The mean ambient river temperature at fish locations detected by mobile tracking in the South Fork Newaukum River was greater than $21^{\circ} \mathrm{C}$ in 1 out of 66 detections ( 1.5 percent). The ambient river temperature for this detection was $21.2{ }^{\circ} \mathrm{C}$ on August 4, 2015, 19.1 river miles upstream of the confluence with the Chehalis River.

For the duration of the study, tagged fish in the Newaukum River were detected in the cool, high-elevation reaches of the subbasin (fig. 12). This spatial distribution likely resulted from active selection by the fish of areas with cooler ambient temperatures. Temperature difference between the mouth and headwaters of the Newaukum River was substantial. For example, in August, there was a 5.9 ${ }^{\circ} \mathrm{C}$ difference in average temperatures between the confluence with the main-stem Chehalis River and the upper extent of the known distribution for spring Chinook salmon. The average ambient temperatures associated with the location of tagged fish in August was $17.9^{\circ} \mathrm{C}$, compared to the average August temperature of $20.2-20.3{ }^{\circ} \mathrm{C}$ in the lower extent of the north and south forks and $21.4{ }^{\circ} \mathrm{C}$ in the main-stem Newaukum River. Movements of tagged fish between the forks of the Newaukum River or into the main stem of the Newaukum River were not observed. 
There was limited evidence that fish selected micro-habitat sites where the tag temperature sensor showed a lower temperature than what was measured for the surrounding area. For detections by the fixed sites, there were 12 cases (five individual fish) where tag sensor data and a temperature logger were matched, allowing a comparison. None of these cases showed a temperature difference more than the $0.8^{\circ} \mathrm{C}$ required to ensure tag sensor accuracy. There was no evidence, therefore, that fish detected by the fixed sites were selecting micro-habitats that provided cooler water temperatures than the ambient temperature. There were 28 cases (seven individual fish) of mobile tracking detections that were matched with an ambient river temperature to allow a comparison. There was no difference in temperature (difference $\leq 0.8^{\circ} \mathrm{C}$ ) in 75 percent of the cases, the fish were in cooler water than the ambient temperature in 4 percent of the cases, and the sensor showed a higher temperature than the ambient temperature in 21 percent of the cases. Similar to the findings for fish detected by the fixed sites, there was little evidence in the mobile tracking records that fish were selecting micro-habitats that provided water cooler than the ambient conditions. Fish 11 in the main-stem Chehalis River near Cloquallum Creek (RM 27.5) showed the largest temperature differential based on mobile tracking data and was the only example of a tagged fish having selected a micro-habitat site cooler than the ambient temperature. On August 19, the tag sensor indicated a selected temperature of $18.8^{\circ} \mathrm{C}$, and the ambient river temperature, as measured by the nearest temperature logger, was $20.6^{\circ} \mathrm{C}$. The differential was 1.8 ${ }^{\circ} \mathrm{C}$, and accounting for the $0.8{ }^{\circ} \mathrm{C}$ to ensure sensor accuracy, the nominal temperature difference showed the fish to be in water $1.0^{\circ} \mathrm{C}$ cooler than the ambient river temperature. Although this example was based on a single tagged fish, the mobile tracking crew that detected the fish noted that there were more than a dozen other (untagged) fish in the same micro-habitat as the tagged fish. The crew also noted that the fish in the area were actively rolling and jumping when the fish location was recorded.

\section{Discussion}

Spring Chinook salmon in the Chehalis River used two strategies to mitigate high summer water temperatures. The warmest summer temperatures in the Chehalis River occurred in the main-stem river during June, July, and August. High-elevation tributaries had substantially cooler water, as did a few deep water areas of the main-stem Chehalis River. Warm summer temperatures pose a substantial problem for adult spring Chinook salmon that must conserve energy for migration and spawning. The first approach to mitigate high water temperatures observed in this study was the timing of major movements that avoided the peak water temperature periods. The second approach was the selection of locations where water temperatures were cooler than surrounding environments in the basin.

The timing of major movements ( $8-10$ river miles) observed in tagged spring Chinook salmon was bi-modal. Following tagging and release, fish in the main-stem Chehalis River either moved quickly upstream or remained in the lower river until cooler water was available in late summer. One tagged fish showed a mix of these approaches, moving quickly upstream a short distance after release and then making a larger movement upstream in late summer, with no documented movements during the peak water temperatures of summer. Similarly, fish tagged in the South Fork Newaukum River, which had already undergone a substantial upstream migration, showed little movement between midJuly and mid-September followed by a redistribution in September, just prior to spawning. Although movements by these fish were on a smaller scale (about 3 river miles) than movements of fish in the main-stem Chehalis River, the pattern of the movement timing was similar. By reducing their activity level during summer, fish can use additional energy resources to mitigate the stress associated with elevated water temperatures and conserve energy for future demands such as migration and reproduction. 
The second temperature mitigation strategy documented in this study was the selection of locations where cool water was available. This behavioral thermoregulation strategy occurred primarily at a large spatial scale where fish selected locations where whole reaches or local areas had cooler water than other nearby areas. Additionally, we observed one example of a tagged fish that occupied a microhabitat where the tag temperature sensor showed a water temperature $1{ }^{\circ} \mathrm{C}$ lower than the ambient river temperatures measured nearby. This fish found this cool water location and used it to mitigate the high water temperatures documented throughout the Chehalis River Basin during the warmest period of summer. Although we only documented a single case of this micro-habitat site-selection strategy, the mobile tracking crew that detected the fish noted that the tagged fish was in an area with more than 12 other (untagged) fish. Additionally, further evidence of this strategy was documented during a 2014 radiotelemetry study of Chinook salmon in the Chehalis River (U.S. Geological Survey, unpub. data, 2014). Although this may be an effective strategy, the availability and seasonal stability of microhabitats that can serve as cold water refuges in the area unknown. Given the projected long-term increases in summer water temperatures and the importance of cool water to spring Chinook salmon, existing cold water refuges might be considered for special protection and restoration efforts could be directed to locations where such micro-habitats might be available. Thus, although not a common observation in 2015, the use of cool water micro-habits is another behavioral thermoregulation strategy used by spring Chinook salmon in the Chehalis River.

The higher elevations of tributary subbasins were $3-6{ }^{\circ} \mathrm{C}$ cooler during summer than the lower extent of each subbasin, forming spatial gradients in temperature that potentially function as cold water refuges. For example, spring Chinook salmon that migrated to the Newaukum River in May and June moved far enough upstream to avoid the temperatures exceeding $21{ }^{\circ} \mathrm{C}$ during summer in the main-stem Newaukum River. Although these fish did not appear to find micro-habitat cold water refuges within their holding reaches, the holding reaches that they occupied averaged $18.1^{\circ} \mathrm{C}$ during summer when water temperatures in much of the Chehalis River exceeded $21^{\circ} \mathrm{C}$.

Tracking 23 radio-tagged spring Chinook salmon during spring and summer 2015 provided valuable insights into how the fish use the Chehalis River Basin. Tagged fish did not move upstream in the Chehalis River past the junction with the Newaukum River, but many fish used the Newaukum River, especially the South Fork Newaukum River. In the Chehalis River, tagged fish congregated near Cedar Creek. The most tagged fish were detected at the fixed site near Cedar Creek, and more than onethird of the fish released in the Chehalis River were last detected in that area. Based on the findings from the 2014 radiotelemetry study (U.S. Geological Survey, unpub. data, 2014) and the known spawning distribution of spring Chinook salmon, the presence of the tagged fish in in the Newaukum River was not surprising. The use of the Cedar Creek area, however, had not been previously reported.

The fates of the study fish indicated that pre-spawn mortality may be an important factor contributing to the successful spawning of spring Chinook salmon in the Chehalis River. Sample sizes of tagged fish in this study, however, were too small to use in deriving an accurate estimate of prespawn mortality for the entire population of spring Chinook salmon in the Chehalis River. In the mainstem Chehalis River, pre-spawn mortality was the fate assigned to 27 percent of the fish (3 of 11). Prespawn mortality was especially apparent in the group of fish tagged in the South Fork Newaukum River. Five of 12 tagged fish (42 percent) were assigned a fate of pre-spawn mortality, and all of them were attributed to predation or harvest. In the Newaukum River, spring Chinook salmon were holding in a limited number of reaches, and the generally shallow nature of this river may increase the vulnerability of these fish to capture. 
The stream temperature monitoring array installed to support this study provided critical data for interpreting spring Chinook salmon movements and temperature selection, and will support future management decisions in the Chehalis River Basin. Daily oscillations in temperatures of both surface and deep microsites in the main-stem river indicated that ambient conditions influenced temperature throughout the summer holding period for spring Chinook salmon. During summer, stream temperature decreased with increased elevation in each of the subbasins except the Black River, which provides minimal contrast in elevation along its stream length. In the Skookumchuck River, an increase of $30 \mathrm{~m}$ (98 ft) elevation corresponded to a $5^{\circ} \mathrm{C}$ decrease in July stream temperatures. Similarly, in the Newaukum River, an increase of $150 \mathrm{~m}$ (492 ft) elevation corresponded to a $6{ }^{\circ} \mathrm{C}$ decrease in July stream temperatures. Along the main stem of the Chehalis River, the relation between summer stream temperatures and elevation followed a concave pattern, with lower temperatures in the lower and upper extents of the main-stem river. Decreasing air temperatures and higher stream gradients may explain the cooler summer temperatures in the upper extent of the main-stem river, and tidal influences may explain the cooler summer temperatures in the lower extent of the main-stem river. Evidence for stratification at sites on the main-stem Chehalis River was minimal. The best evidence came from the paired surfacedeep loggers at RM 74.7. This location, known to local fishers as "Scheuber hole", has been associated with multiple observations of spring Chinook salmon in recent years including radiotelemetry detections in the current study, a pilot study in 2014 (U.S. Geological Survey, unpub. data, 2014), and a fish kill in 2009 (Mike Kohn, Lewis County Public Utility District, written commun., 2009).

Monitoring the movements and temperature selection of spring Chinook salmon during spring and summer 2015 was fortuitous in that this year was an atypical year in regard to water availability and stream temperatures. In 2015, little to no precipitation occurred throughout the basin between March and September, which resulted in lower streamflows, and consequently warmer stream temperatures than in typical years. As a result, the ambient river environment encountered by spring Chinook salmon as they entered freshwater was warmer, with lower flows, earlier in the season than what these fish would experience during a typical summer in the Chehalis River. Additionally, these conditions persisted longer than usual throughout the summer as these fish were holding and moving to spawning locations.

None of the tagged fish entered the Skookumchuck River, despite the availability of cooler water there than anywhere else in the basin and sufficient water depth to maintain accessibility throughout the summer. In the Chehalis River Basin, the Skookumchuck River has the largest spawning populations of spring Chinook salmon of any other subbasin. The 2014 radiotelemetry study of spring Chinook salmon movements in the Chehalis River documented several tagged fish holding near the Skookumchuck River mouth, and moving substantial distances upstream (U.S. Geological Survey, unpub. data, 2014). Based on those findings and the known distribution of Chinook salmon in the Chehalis River Basin, we anticipated a fraction of the tagged fish from this study spending time in the Skookumchuck River for at least short durations. No tagged fish were detected at the fixed site monitoring the lower Skookumchuck River, and all fish detected at the mouth of the Skookumchuck River had detection histories that showed continued upstream movement or residence at the river mouth. Therefore, there were no fish that might have moved undetected past the lower Skookumchuck River fixed site. The monthly bathythermograph surveys of the area documented that several access channels were available to fish, even during the low water period in mid-summer, so the inability to access the tributary was not the controlling factor behind the lack of use of the tributary. Overall low sample size, and specifically the low numbers of fish that moved through this section of the river, seem to be the most plausible explanation for this observation. 
Of the 11 fish released in the Chehalis River, only 4 fish moved upstream to the area near the mouth of the Skookumchuck River. One of these fish remained near the river mouth with detections into the spawning period. The three other fish had short residence times at the mouth of the Skookumchuck River, and ultimately moved into the Newaukum River where they were last detected during the spawning period. Use of the Skookumchuck River likely would have been noted during the study, with a larger number of tagged fish to monitor.

The collection of spring Chinook salmon for tagging was challenging and resulted in an unplanned, but useful approach. The goal was to collect fish as low in the basin as possible so that the movement of fish upstream could be monitored. The fish were difficult to collect, and even with substantial effort with multiple gear types, fewer fish were tagged than desired. The run timing and size were difficult to evaluate in the Chehalis River, but the impression gathered from local guides and fishermen was that the numbers of fish were less than typical numbers for April-June when we focused our collection efforts. By about mid-June, it became apparent that we would not likely be able to collect and tag a large number of fish in the Chehalis River. The water temperatures were increasing, causing concern for the condition of the fish owing to the stresses of capture and tagging. Some of the collection and tagging effort, therefore, was directed to the Newaukum River. With 2 weeks of effort, crews were able to collect and tag 12 fish in the South Fork Newaukum River near known spawning areas. It is not clear when these fish entered the Chehalis River Basin or why we were not able to collect some of them in the lower Chehalis River. As these fish were collected, tagged, and released early in the season near their spawning grounds, we estimated that they would have a more limited range of movements compared to the fish captured in the lower Chehalis River. The monitoring options for these fish also were limited in that none of the fixed sites were located in the South Fork Newaukum River. Mobile tracking efforts were focused in this area to monitor the movements and temperature selections of these fish. The challenges of collecting fish for the study, therefore, forced a dichotomous approach to monitoring and describing fish movements in the Chehalis River Basin. Although it was not a planned approach, it proved to be a useful approach, contributing to our understanding of fish movements and temperature selection through a large area of the Basin

The method used to obtain stream temperatures using loggers at the deep microsites had some unexpected complications. Data gaps in the time series occurred at one-half of the paired temperature logger sites because of the unauthorized removal of the deep loggers. The cabling used to anchor the surface loggers was more effectively hidden from view as compared to the deep loggers where the cable was extended into the deepest part of the channel. Additionally, the areas where the deep loggers were deployed often were associated with summer recreational use (that is, swimming, fishing), which increased human presence and, therefore, increased the risk of discovery and loss. In the future, more reliable methods of obtaining temperature profiles may be used such as instantaneous profiles collected at stationary locations several times over the summer holding period such as those used for the bathythermograph surveys completed for this study.

The water temperature selection results reported for this study are reliable, but some censoring of temperature data was required because of poor sensor performance. Prior to the start of the study, the controlled testing described in appendix A documented that all transmitter temperature sensors performed within manufacturer specifications across the range of temperatures that fish in the Chehalis River might experience. However, during the field season, there were instances of questionable sensor performance for six tags (all from the 2014 tag collection), and post-season testing of four of these tags that were able to be recovered showed that the sensors did not perform reliably (see section, "Summary" in appendix A). One of the four tags recovered for testing had no remaining battery life at the time of testing, despite the predicted battery life of $419 \mathrm{~d}$ and the actual 2015 study period maximum of $215 \mathrm{~d}$ 
(April-October). This finding suggested that the battery either failed prematurely or it was being partially expended during winter 2014-15, while waiting to be used in the 2015 study. As battery life fails on a transmitter, some functionality may be compromised. For example, the radio signal strength may be reduced. The post-season testing provided some evidence that the temperature sensor in the 2014 tags did not function at full capability with reduced battery life. There were no instances of questionable sensor performance for the tags manufactured in 2015, which were deployed with the full battery capacity. However, only 17 percent ( 4 of 23) of the study fish were tagged using 2015 tags, as 19 of 23 tagged fish had the older tags from 2014. Although the findings of the post-season testing may raise questions about the sensor data reported here, careful data review and screening was conducted to ensure reliability of the results. None of the six tags of concern were used in analyses related to fish temperature selection, and all remaining tag records were screened using signal strength as well as consistency and soundness of sensor data before being used in analyses. As radio transmitters are expensive, it is relatively common practice for tags to be recovered or saved and passed from one study to another. Although compromised battery life may not affect the ability to locate and position fish, at least until the battery expires, the post-season testing done for this study suggests that caution be used when older tags with sensors are used. Additionally, documenting the activation and deactivation times for each use of a transmitter will aid researchers in estimating remaining battery life and guiding future potential uses of the tag.

The combined monitoring approach used during this study added substantially to the understanding of spring Chinook salmon movements in the Chehalis River. The array of fixed sites allowed us to monitor the large-scale movements of tagged fish and to monitor fish temperature selection continuously while fish were within range of a fixed site. The mobile tracking efforts allowed fish to be positioned on a finer scale between the fixed-site locations and in areas outside the array, such as the Newaukum River. Continuing the mobile tracking through the spawning season was helpful in describing the final locations for tagged fish and to recover transmitters. Without the effort to recover tags at the end of the season, the post-season sensor testing would not have been conducted. The combination of the two monitoring approaches allowed us to generate detailed detection histories for most of the tagged fish. For future studies where fish temperature selection is monitored, we suggest adding additional fixed sites in locations where fish are likely to aggregate and hold, with stream temperature monitoring near each site. Although fixed sites for this study were selected based on anticipated holding areas, few fish had extended residence times within range of our sites. To address questions related to fish temperature selection, the most powerful dataset for analyses will be generated when fish spend several days within range of a fixed site. The long record of sensor data will allow validation of the sensor data with known stream temperatures and the elimination of records with low signal strength or radio frequency interference that can produce high variability in sensor data. Mobile tracking data are useful for positioning fish, but are less so for evaluating temperature selection because they typically are point samples or short (minutes) time series.

This study describes the movements and behavior of spring Chinook salmon from their entry into freshwater through their spawning period in 2015, and represents a substantial contribution to the understanding of these fish in the Chehalis River. The water temperature and flow conditions during the study period were not typical of the historical conditions in the basin, and the numbers of tagged fish monitored was relatively low, so results should be interpreted with those cautions in mind. The stream temperatures and bathythermograph profiles collected during the study documented the extreme temperature and flow conditions during 2015 and will be a useful resource to researchers and managers for future applications, as efforts continue to protect spring Chinook salmon in the Chehalis River Basin. 


\section{Acknowledgments}

The authors gratefully acknowledge Mark White and Mike Mizell (Chehalis Tribe Department of Natural Resources); Mike Kohn (Lewis County Public Utility District); Brett Ferris (Ferris Northwest Guide Service); Nick Norbeck (Nick Norbeck Elite Guide Service); Chris White, Kim Figlar-Barnes, John Serl, Amy Edwards, Eric Walther, Steve Anderson, John McCulloch, Dave Smith, Ray Bissonette, Barb McLellan, and Mike Scharpf (Washington Department of Fish and Wildlife); and Brian Ekstrom, Andrew Wells, William Hurst, Gabe Hansen, Toby Kock, and Matt Sholtis (U.S. Geological Survey) for their contributions to the funding, field activities, and reporting. Map was generated by Dale Gombert (Washington Department of Fish and Wildlife).

\section{References Cited}

Alabaster, J. S., 1988, The dissolved oxygen requirements of upstream migrant Chinook salmon, Oncorhynchus tshawytscha, in the lower Willamette River, Oregon: Journal of Fish Biology, v. 32, p. 635-636.

Aquatic Species Enhancement Plan Technical Committee, 2014, Aquatic species enhancement plan: Prepared for the Chehalis Basin Work Group, $154 \mathrm{p}$.

Berman, C.H., 1990, Effect of elevated holding temperatures on adult spring Chinook salmon reproductive success: Seattle, University of Washington, Master's thesis, $102 \mathrm{p}$.

Berman, C.H., and Quinn, T.P., 1991, Behavioural thermoregulation and homing by spring Chinook salmon, Oncorhynchus tshawytscha (Walbaum), in the Yakima River: Journal of Fish Biology, v. 39, p. 301-312.

Caissie, D., 2006, The thermal regime of rivers-A review: Freshwater Biology, v. 51, no. 8, p. 1,3891,406 .

Dauble, D.D., and Mueller, R.P., 1993, Factors affecting the survival of upstream migrant adult salmonids in the Columbia River Basin-Recovery issues for threatened and endangered Snake River salmon: Final Report to the U.S. Department of Energy, Bonneville Power Administration, Division of Fish and Wildlife, Portland, Oregon, Project number 988-026.

Dugdale, S.J., Bergeron, N.E., and St.-Hilaire, A., 2015, Spatial distribution of thermal refuges analyzed in relation to riverscape hydromorphology using airborne thermal infrared imagery: Remote Sensing of Environment, v. 160, p. 43-55.

Ebersole, J.L., Liss, W.J., and Frissell, C.A., 2003, Thermal heterogeneity, stream channel morphology, and salmonid abundance in northeastern Oregon streams: Canadian Journal of Fisheries and Aquatic Sciences, v. 60 , p. 1,266-1,280.

Fresh, K.L., Schroder, S.L., and Carr, M.I., 2003, Predation by northern pikeminnow on hatchery and wild coho salmon smolts in the Chehalis River, Washington: North American Journal of Fisheries Management, v. 23, p. 1,257-1,264.

Goniea, T.M., Keefer, M.L., Bjornn, T.C., Peery, C.A., Bennett, D.H., and Stuehrenberg, L.C., 2006, Behavioral thermoregulation and slowed migration by adult fall Chinook salmon in response to high Columbia River water temperatures: Transactions of the American Fisheries Society, v. 135, p. 408-419.

Healey, M.C, 1991, Life history of Chinook salmon (Onchorhynchus tshawytscha), in Groot, C., and Margolis, L., eds., Pacific salmon life histories: Vancouver, University of British Columbia Press, p. 312-393.

Hearsey, J.W., and Kinziger, A.P., 2015, Diversity in sympatric Chinook salmon runs-Timing, relative fat content and maturation: Environmental Biology of Fishes, v. 98, p. 413-423.

Henning, J.A., and Schirato, G., 2006, Amphibian use of Chehalis River floodplain wetlands: Northwestern Naturalist, v. 87, p. 209-214.

Henning, J.A., Gresswell, R.E., and Fleming, I.A., 2007, Use of seasonal freshwater wetlands by fishes in a temperate river floodplain: Journal of Fish Biology, v. 71, p. 476-492. 
Hiss, J.M., and Knudsen, E.E., 1993, Chehalis River Basin fishery resources - Status, trends, and restoration: Final report by the U.S. Fish and Wildlife Service, 37 p., accessed January 8, 2016, at http://www.fws.gov/wafwo/fisheries/Publications/FP069exsum_ch1-2.pdf.

Isaak, D.J., Horan, D.L., and Wollrab, S.P., 2013, A simple protocol using underwater epoxy to install annual temperature monitoring sites in rivers and streams: U.S. Forest Service General Technical Report RMRS-GTR, v. 314, 21 p.

Keefer, M.L., Peery, C.A., Ringe, R.R., and Bjornn, T.C., 2004, Regurgitation rates of intragastric radio transmitters by adult Chinook salmon and steelhead during upstream migration in the Columbia and Snake Rivers: North American Journal of Fisheries Management, v. 24, p. 47-54.

Kelsh, S.W., and Shields, B., 1996, Care and handling of sampled organisms, in Murphy, B.R., and Willis, D.W., eds., Fisheries Techniques, $2^{\text {nd }}$ edition, American Fisheries Society, Bethesda, Maryland.

Kuehne, L.M., and Olden, J.D., 2016, Environmental drivers of occupancy and detection of Olympic Mudminnow: Transactions of the American Fisheries Society, v. 145, no. 1, p. 17-26.

Moser, M.L., Olson, A.F., and Quinn, T.P., 1991, Riverine and estuarine migratory behavior of coho salmon (Oncorhynchus kisutch) smolts: Canadian Journal of Fisheries and Aquatic Sciences, v. 48, p. 1,670-1,678.

Quinn, T.P, 2011, The behavior and ecology of Pacific salmon and trout: Vancouver, University of British Columbia Press, American Fisheries Society, 320 p.

Quinn, T.P., McGinnity, P., and Reed, T.E., 2015, The paradox of 'premature migration' by adult anadromous salmonid fishes - Patterns and hypotheses: Canadian Journal of Fisheries and Aquatic Sciences, doi:10.1139/cjfas-2015-0345.

Rahel, F.J., and Hubert, W.A., 1991, Fish assemblages and habitat gradients in a Rocky Mountain-Great Plains stream-Biotic zonation and additive patterns of community change: Transactions of the American Fisheries Society, v. 120, p. 319-332.

Richter, A., and Kolmes, S.A., 2005, Maximum temperature limits for Chinook, coho, and chum salmon and steelhead trout in the Pacific Northwest: Reviews in Fisheries Science, v. 13, p. 23-49.

Rieman, B.E., and Chandler, G.L., 1999, Empirical evaluation of temperature effects on bull trout distribution in the Northwest: Final Report to U.S. Environmental Protection Agency, Boise, Idaho, contract number 12957242-01-0.

Rieman, B.E., and McIntyre, J.D., 1995, Occurrence of bull trout in naturally fragmented habitat patches of varied size: Transactions of the American Fisheries Society, v. 124, p. 285-296.

Smith, C.E., Dwyer, W.P., and Piper, R.G, 1983, Effect of water temperature on egg quality of cutthroat trout: The Progressive Fish Culturist, v. 43, p. 176-178.

Smith, C.J., and Wenger, M., 2001, Salmon and steelhead habitat limiting factors - Chehalis Basin and nearby drainages water resource inventory areas 22 and 23: Final report by the Washington State Conservation Commission, 448 p., accessed January 8, 2016, at http://www.ecy.wa.gov/programs/wq/tmdl/ChehalisBasin/SalmonHabLimitFactors.pdf.

Sullivan, K.D., Martin, D.J., Carwell, R.D., Toll, J.E., and Duke, S., 2000, An analysis of the effects of temperature on salmonids of the Pacific Northwest with implications for selecting temperature criteria: Final report by Suitable Ecosystems Institute, Portland, Oregon, 192 p.

Tiffan, K.F., Kock, T.J., Connor, W.P., Steinhorst, R.K., and Rondorf, D.W., 2009, Behavioral thermoregulation by subyearling fall (autumn) Chinook salmon Oncorhynchus twsawytscha in a reservoir: Journal of Fish Biology, v. 74, p. 1,562-1,579.

Torgersen, C.E., Price, D.M., Li, H.W., and McIntosh, B.A., 1999, Multiscale thermal refugia and stream habitat associations of Chinook salmon in northeastern Oregon: Ecological Applications, v. 9, p. 301-319. Washington Department of Fish and Wildlife, 2016, SalmonScape database Washington Department of Fish and Wildlife interactive mapping application, accessed March 15, 2016, at http://apps.wdfw.wa.gov/salmonscape/map.html. 


\section{Appendix A. Controlled Tests of Transmitter Temperature Sensor Performance}

The transmitters (also known as tags) used for this study were equipped with temperature sensors. As the water temperature data collected from these sensors was a critical part of the evaluation, the sensors were tested in a series of controlled laboratory tests prior to the start of the field study. The sensor in the transmitter can record temperatures from -6 to $34{ }^{\circ} \mathrm{C}$ and is accurate to $\pm 0.8^{\circ} \mathrm{C}$, according to the manufacturer $\left(\right.$ Lotek $\left.^{(}\right)$Wireless Incorporated, Newmarket, Ontario, Canada).

Testing was conducted prior to the field component of the study (pre-season testing) as well as after the field component of the study (post-season testing). The pre-season tests were to confirm reliable function of the tags. The post-season testing was conducted because field observations suggested that some tags did not appear to be generating reliable sensor data relative to measured river temperatures. Some of the questionable tags were recovered in the field and were tested in a controlled setting to determine if their function was compromised.

The collection of tags used for the field study was from two sources. About one-half of the tags were purchased in 2014 for a different study, but either were not used in fish or were used and then later recovered. These tags were stored through winter 2014-15 and were used for the current study starting in spring 2015. The remaining tags were purchased and manufactured in 2015. The 2014 tags were all on a single frequency $(167.400 \mathrm{MHz})$ and the 2015 tags were all on a separate frequency (164.144 $\mathrm{MHz}$ ). The pre-season laboratory tests were conducted using tags from 2014 and 2015 to evaluate any potential differences in performance owing to the age of the tags.

\section{Pre-Season Sensor Testing}

\section{Experiment Number 1}

The first experiment tested the transmitter in fish as compared to the water temperature. Four rainbow trout (Oncorhynchus mykiss) received gastric implantations of transmitters and were placed into 1.5-mdiameter (1.2-m-deep) fiberglass tanks. Two fish were tested at water temperatures near $14{ }^{\circ} \mathrm{C}$ and two fish were tested at water temperatures near $7^{\circ} \mathrm{C}$. The water temperature in the tank was measured using temperature loggers positioned near the water surface and on the bottom of the tank. Preliminary testing showed that the temperature loggers at the surface and the bottom of the tank did not vary from each other by more than $0.1^{\circ} \mathrm{C}$, so the tanks were well mixed. The mean water temperature from the two temperature loggers was used to represent the water temperature in the tank for comparisons with the transmitter sensor. Fish were tagged, placed in the tanks, and allowed to acclimate overnight. The following day, a telemetry receiver and an underwater antenna were used to record the transmitter sensor readings for about $2 \mathrm{~h}$. After the test was complete, the temperature loggers and telemetry receiver were downloaded and comparisons between water temperature and sensor temperature were made. We calculated the absolute value of the difference between the temperature recorded by the sensor and the temperature recorded by the loggers, hereinafter "delta". For each transmitter, we calculated the percentage of records that were out of compliance, based on the expected accuracy of $\pm 0.8^{\circ} \mathrm{C}$. Records were out of compliance if delta exceeded $0.85{ }^{\circ} \mathrm{C}$. 
Overall, the four tested transmitter sensors showed good accuracy while implanted in fish. Three of four tags tested were in compliance more than 99 percent of the time, and one tag was out of compliance during 6.7 percent of the test (table A1). The individual tag sensor readings and the individual temperature logger readings to which they were compared are shown in figure A1. Note that delta is consistently less than $0.85^{\circ} \mathrm{C}$ (sensor in compliance) for the early and middle parts of the record, and then delta increases substantially before it stabilizes again near the end of the record. This short, but highly irregular period of tag sensor data accounts for the entire out of compliance incidences for this tag. If the tag sensor record is terminated just prior to this irregular period, the mean delta is 0.26 ${ }^{\circ} \mathrm{C}$, with a minimum of $0.19{ }^{\circ} \mathrm{C}$ and a maximum of $0.61{ }^{\circ} \mathrm{C}$, with no records out of compliance.

A detailed review of the tag-detection record for tag 3 (tag ID 40023, table A1) indicated evidence of radio frequency interference during the first experiment. The signal strength (an indicator of how well the radio signal was received) was variable, and not every pulse of the tag was detected by the receiver (as it should be under ideal conditions). Based on experience reviewing telemetry receiver records for numerous other studies, we believe that the ability of the receiver to detect the tag sensor was briefly compromised because of interference from an unknown source. Events such as this, where an unknown source of interference causes a short-term reduction in receiver ability, are relatively common in field settings where radio signals are common. For data analyses, these effects generally are well mitigated by filters on receivers and data proofing processes. Although it likely did not occur in the controlled laboratory testing, another potential cause of variability in radio signal detection is distance from the tag. In the laboratory testing, the distance from the antenna to the tag was relatively constant and consistently optimized as the fish were restricted to the confines of the tank. In a field setting, a relatively weak signal detected by the receiver may cause unreliable temperature sensor readings.

Table A1. Radio transmitter temperature sensor testing under controlled laboratory conditions, March 2015.

[Four tags were gastrically inserted into rainbow trout (Oncorhynchus mykiss), and fish were held at two water temperatures to evaluate the accuracy of the temperature sensor in the tag when tags were implanted in fish. Tag sensor data were collected for 2 hours, averaged (overall sensor temperature), and then compared to the average water temperature from temperature loggers placed in the tank (overall water temperature). The difference in water temperature (delta) mean, minimum, and maximum are reported. The number of sensor records that were more than 0.8 degrees Celsius $\left({ }^{\circ} \mathrm{C}\right)$ different from the water temperature recorded at the same time were noted (records out of compliance), as well as the percentage of records that were out of compliance (greater than $0.8^{\circ} \mathrm{C}$ )]

\begin{tabular}{cccccccccc}
\hline $\begin{array}{c}\text { Tag } \\
\text { ID }\end{array}$ & $\begin{array}{c}\text { Tag } \\
\text { number }\end{array}$ & $\begin{array}{c}\text { Overall } \\
\text { water } \\
\text { temperature } \\
\left({ }^{\circ} \mathrm{C}\right)\end{array}$ & $\begin{array}{c}\text { Overall } \\
\text { sensor } \\
\text { temperature } \\
\left({ }^{\circ} \mathrm{C}\right)\end{array}$ & $\begin{array}{c}\text { Delta } \\
\text { mean } \\
\left({ }^{\circ} \mathrm{C}\right)\end{array}$ & $\begin{array}{c}\text { Delta } \\
\text { minimum } \\
\left({ }^{\circ} \mathrm{C}\right)\end{array}$ & $\begin{array}{c}\text { Delta } \\
\text { maximum } \\
\left({ }^{\circ} \mathrm{C}\right)\end{array}$ & $\begin{array}{c}\text { Sensor } \\
\text { records }\end{array}$ & $\begin{array}{c}\text { Records } \\
\text { out of } \\
\text { compliance }\end{array}$ & $\begin{array}{c}\text { Out of } \\
\text { compliance } \\
\text { (percentage) }\end{array}$ \\
\hline 40010 & 1 & 13.98 & 13.59 & 0.41 & 0.33 & 1.23 & 1,123 & 5 & 0.45 \\
40045 & 2 & 13.62 & 13.97 & 0.39 & 0.02 & 1.21 & 106 & 1 & 0.94 \\
40023 & 3 & 6.66 & 6.81 & 0.52 & 0.01 & 3.79 & 209 & 14 & 6.70 \\
40030 & 4 & 6.92 & 7.60 & 0.68 & 0.01 & 0.84 & 227 & 0 & 0.00 \\
\hline
\end{tabular}



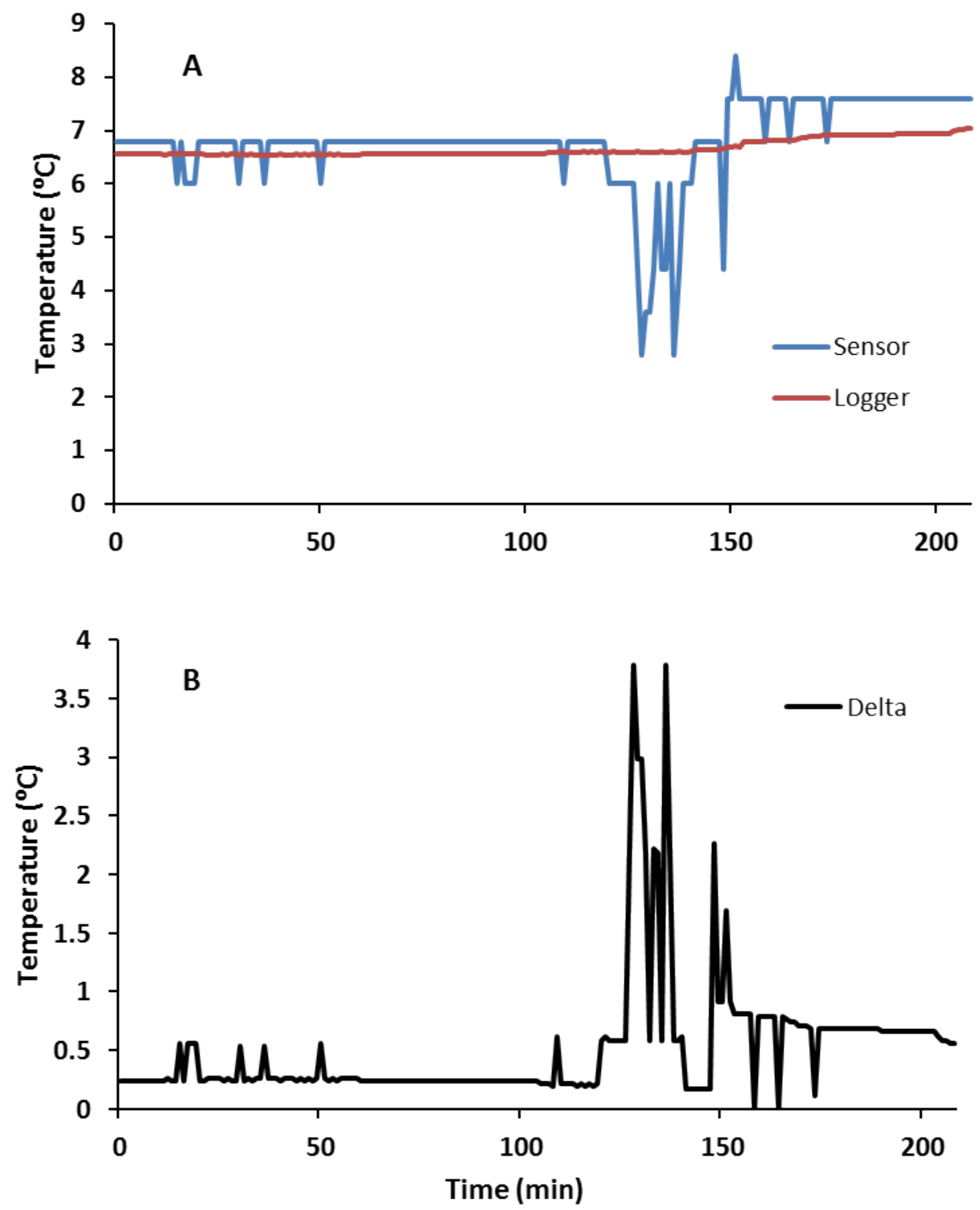

Figure A1. Graphs showing transmitter temperature sensor (sensor), temperature logger water temperatures (logger), and the difference in temperature (delta) between the sensor and the logger during controlled laboratory testing, March 2015. 
The first experiment to test the performance of the tag sensor while in fish showed that the sensors performed within specifications when tested in fish. We noted some events that were out of specifications when radio frequency interference was present. As this interference is likely to occur during the field evaluation, we suggest several mitigation measures. For fixed-site telemetry records, tag sensor data will be proofed so that no single temperature sensor record will be used for analysis. Groups of consistent temperature sensor records within a short period of time (for example, 5 min) will be averaged to represent the water temperature selected by a fish. Additionally, sensor readings associated with low receiver signal strength will be removed and not included in analyses. For mobile tracking efforts, the standard operating procedure will require that tag sensor data be monitored for 5 min prior to recording a sensor reading associated with a fish position. This approach will help to control the influence of radio frequency interference as the mobile tracker will be able to evaluate the strength and stability of the sensor reading and begin timing the 5-min monitoring period once readings are strong and stable.

\section{Experiment Number 2}

The second experiment was designed to test individual tag sensor function with known water temperatures. We randomly selected 13 tags from the 2014 tag collection, which had been stored for several months because they were not used in the pilot-level 2014 Chehalis River radiotelemetry study. We were concerned that tags produced in 2014 might have compromised functionality, at least in regard to the temperature sensor. The tags were individually placed in 1.5-m-diameter (1.2-m-deep) fiberglass tanks along with two temperature loggers. Tags were positioned in the tank using a plastic tube so that all tags had a consistent orientation and distance from the receiver antenna. The body of the tag was positioned closest to the receiving antenna, and the tag antenna was pointed away from the receiving antenna. The receiver gain was adjusted to maximize signal strength prior to testing, and then was not adjusted during testing. The tank was monitored with a single underwater antenna connected to a telemetry receiver. An individual tag was placed in the tank, and $5 \mathrm{~min}$ of sensor data were collected after a 5-min acclimation period. The tag sensor temperature reading was compared to the mean logger temperature.

All 13 randomly selected tags tested in the second experiment were within the expected accuracy of the tag (table A2). Water temperature ranged from 6.8 to $7.6^{\circ} \mathrm{C}$ during the testing, and received signal strength was consistent and high. The minimum delta was $0.1{ }^{\circ} \mathrm{C}$ and the maximum delta was $0.66{ }^{\circ} \mathrm{C}$ (table A2). For 12 of 13 tags, the sensor gave the same reading throughout the test period. One tag sensor generated three temperature readings within the time it was tested, but the delta still was within specifications. This experiment provided evidence that the tags purchased in 2014 were functioning well and could be reliably used for the 2015 radiotelemetry evaluation in the Chehalis River. 
Table A2. Radio transmitter temperature sensor testing under controlled laboratory conditions, March 2015.

[Transmitters (tag ID) were randomly selected from the collected of tags purchased in 2014 to test the accuracy of the temperature sensor. Tags were positioned in small tanks that contained a temperature logger to monitor water temperature and to serve as the basis for comparison. All tags were positioned identically to optimize signal strength and reduce interference. Tags were placed in the tank for 2 minutes and then sensor data was collected for 2 minutes. The sensor data was averaged (mean sensor temperature, in degrees Celsius $\left[{ }^{\circ} \mathrm{C}\right]$ ) and compared to the mean logger temperature to calculate the difference (delta). The number of sensor records, the mean signal strength and the percentage of the sensor record (\%) that demonstrated that signal strength and the variability of the sensor data record (sensor variability) are reported]

\begin{tabular}{|c|c|c|c|c|c|c|}
\hline Tag ID & $\begin{array}{c}\text { Mean sensor } \\
\text { temperature } \\
\left({ }^{\circ} \mathrm{C}\right)\end{array}$ & $\begin{array}{l}\text { Mean logger } \\
\text { temperature } \\
\left({ }^{\circ} \mathrm{C}\right)\end{array}$ & $\begin{array}{l}\text { Delta } \\
\left({ }^{\circ} \mathrm{C}\right)\end{array}$ & $\begin{array}{l}\text { Number of } \\
\text { sensor } \\
\text { records }\end{array}$ & $\begin{array}{l}\text { Mean signal } \\
\text { strength }\end{array}$ & Sensor variability \\
\hline 40001 & 6.8 & 6.56 & 0.24 & 72 & 255 (100\%) & $\begin{array}{l}\text { no variability--same reading } \\
\text { throughout test }\end{array}$ \\
\hline 40010 & 6.8 & 6.59 & 0.22 & 64 & 255 (100\%) & $\begin{array}{l}\text { no variability--same reading } \\
\text { throughout test }\end{array}$ \\
\hline 40017 & 6.8 & 6.59 & 0.22 & 75 & 255 (100\%) & $\begin{array}{l}\text { no variability--same reading } \\
\text { throughout test }\end{array}$ \\
\hline 40018 & 6.8 & 6.59 & 0.22 & 63 & 255 (100\%) & $\begin{array}{l}\text { no variability--same reading } \\
\text { throughout test }\end{array}$ \\
\hline 40022 & 6.8 & 6.61 & 0.19 & 59 & 255 (100\%) & $\begin{array}{l}\text { no variability--same reading } \\
\text { throughout test }\end{array}$ \\
\hline 40023 & 6.8 & 6.79 & 0.01 & 58 & 255 (100\%) & $\begin{array}{l}\text { no variability--same reading } \\
\text { throughout test }\end{array}$ \\
\hline 40026 & 6.8 & 6.81 & 0.01 & 60 & 255 (100\%) & $\begin{array}{l}\text { no variability--same reading } \\
\text { throughout test }\end{array}$ \\
\hline 40028 & 7.6 & 6.86 & 0.74 & 55 & 255 (100\%) & $\begin{array}{l}\text { no variability--same reading } \\
\text { throughout test }\end{array}$ \\
\hline 40030 & 7.6 & 6.89 & 0.71 & 84 & 255 (100\%) & $\begin{array}{l}\text { no variability--same reading } \\
\text { throughout test }\end{array}$ \\
\hline 40031 & 7.6 & 6.94 & 0.66 & 72 & 255 (100\%) & $\begin{array}{l}\text { no variability--same reading } \\
\text { throughout test }\end{array}$ \\
\hline 40032 & 7.6 & 6.98 & 0.38 & 54 & 255 (100\%) & $\begin{array}{l}67 \% \text { of record was } 7.6,321 \% \text { was } \\
6.8 \text { and } 2 \% \text { was } 8.4\end{array}$ \\
\hline 40040 & 7.6 & 7.02 & 0.58 & 60 & 255 (100\%) & $\begin{array}{l}\text { no variability--same reading } \\
\text { throughout test }\end{array}$ \\
\hline 4004 & 7.6 & 7.08 & 0.52 & 56 & 255 (100\%) & $\begin{array}{l}\text { no variability--same reading } \\
\text { throughout test }\end{array}$ \\
\hline
\end{tabular}




\section{Experiment Number 3}

A third experiment was conducted to test tag sensor function over the range of water temperatures specified by the manufacturer. Although the tag sensor is specified to be able to detect temperatures as low as $-6{ }^{\circ} \mathrm{C}$, we used $0{ }^{\circ} \mathrm{C}$ as our lowest tested temperature as we did not anticipate field conditions outside that range. For this test, we conducted two trials: one with tags from the 2014 tag order and one with tags from the 2015 order. For each trial, we used 10 randomly selected tags, and five water temperatures, ranging from 0 to $34^{\circ} \mathrm{C}$. Tests were conducted in 19-L containers, with a temperature logger and an underwater antenna placed in the container along with the tag. Tags were placed in the container for $5 \mathrm{~min}$ to acclimate and then $5 \mathrm{~min}$ of data were collected on the telemetry receiver. The mean water temperature from the logger was compared to the mean water temperature from the tag, and delta was calculated.

In all 30 cases ( 3 tags per temperature per trial), the delta was less than $0.85^{\circ} \mathrm{C}$, and tag sensors were within specifications (table A3). The mean delta was $0.3^{\circ} \mathrm{C}$, with a minimum of $0.1{ }^{\circ} \mathrm{C}$ and a maximum of $0.6^{\circ} \mathrm{C}$. The mean received signal strength was high and consistent with no evidence of radio frequency interference. This experiment provided evidence that both the 2014 and 2015 tags performed well over the full range of temperatures that the sensor is likely to encounter in the field study.

\section{Summary}

In summary, the pre-season tag sensor testing that was conducted provided evidence that the tag sensors accurately measured water temperatures. We found no evidence that the sensors performed differently when implanted in a fish as compared to outside a fish, and no evidence that the older 2014 transmitters had reduced performance relative to the newly produced 2015 transmitters. There was evidence, however, that low received signal strength and radio frequency interference can lead to irregular and erroneous tag sensor readings. Data collection and data processing protocols were put in place to control for this potential bias. The protocols for collecting tag sensor data while mobile tracking require monitoring the tag signal until it is stable and strong (high signal strength) and then waiting about $5 \mathrm{~min}$ to record the tag sensor temperature. The protocols for processing data from the fixed-site receiving stations dictate that single detections of a tag or highly variable tag sensor readings should not be included in the tag-detection record for a given fish. Consistent application of these protocols will result in reliably accurate water temperature data from the tag sensors. 
Table A3. Radio transmitter temperature sensor testing under controlled laboratory conditions to evaluate the function of the sensor over a range of water temperatures, March 2015.

[Five water temperatures were tested (test temperature, in degrees Celsius $\left[{ }^{\circ} \mathrm{C}\right]$ ) during two trials. Trial 1 included 10 randomly selected tags purchased in 2014 and trial 2 included 10 randomly selected tags purchased in 2015 . Tags were individually placed in small containers of water along with a temperature logger. After a 5-minute acclimation period, 5 minutes of sensor data were collected. The mean sensor temperature was compared to the mean water temperature collected by the logger to generate the difference in temperature (delta). The number of sensor records used for the comparison and the mean signal strength of the sensor records are reported]

\begin{tabular}{|c|c|c|c|c|c|c|c|}
\hline Trial & $\begin{array}{c}\text { Test } \\
\text { temperature } \\
\left({ }^{\circ} \mathrm{C}\right)\end{array}$ & Tag ID & $\begin{array}{c}\text { Mean sensor } \\
\text { temperature } \\
\left({ }^{\circ} \mathrm{C}\right)\end{array}$ & $\begin{array}{c}\text { Mean water } \\
\text { temperature } \\
\left({ }^{\circ} \mathrm{C}\right)\end{array}$ & $\begin{array}{l}\text { Delta } \\
\left({ }^{\circ} \mathrm{C}\right)\end{array}$ & $\begin{array}{l}\text { Number of } \\
\text { sensor } \\
\text { records }\end{array}$ & $\begin{array}{c}\text { Mean } \\
\text { signal } \\
\text { strength }\end{array}$ \\
\hline \multirow[t]{3}{*}{1} & 0 & 40018 & 0.4 & 0.0 & 0.4 & 72 & 255 \\
\hline & & 40031 & 0.4 & 0.0 & 0.4 & 72 & 255 \\
\hline & & 40032 & 0.4 & 0.0 & 0.4 & 72 & 253 \\
\hline \multirow[t]{3}{*}{1} & 11 & 40010 & 11.6 & 11.1 & 0.5 & 73 & 255 \\
\hline & & 40022 & 11.6 & 11.1 & 0.5 & 72 & 253 \\
\hline & & 40023 & 11.6 & 11.1 & 0.5 & 69 & 255 \\
\hline \multirow[t]{3}{*}{1} & 19 & 40018 & 19.3 & 18.9 & 0.4 & 64 & 255 \\
\hline & & 40026 & 18.8 & 18.9 & 0.1 & 64 & 255 \\
\hline & & 40028 & 18.8 & 18.9 & 0.1 & 64 & 255 \\
\hline \multirow[t]{3}{*}{1} & 23 & 40026 & 22.8 & 22.9 & 0.1 & 68 & 255 \\
\hline & & 40031 & 22.8 & 22.9 & 0.1 & 67 & 255 \\
\hline & & 40045 & 22.8 & 22.9 & 0.1 & 70 & 255 \\
\hline \multirow[t]{3}{*}{1} & 34 & 40010 & 33.5 & 33.7 & 0.1 & 60 & 255 \\
\hline & & 40023 & 33.6 & 33.7 & 0.1 & 66 & 255 \\
\hline & & 40040 & 33.6 & 33.7 & 0.1 & 64 & 255 \\
\hline \multirow[t]{3}{*}{2} & 0 & 14009 & 0.4 & 0.0 & 0.4 & 71 & 255 \\
\hline & & 14015 & 0.4 & 0.0 & 0.4 & 68 & 255 \\
\hline & & 14019 & 0.3 & 0.0 & 0.3 & 69 & 255 \\
\hline \multirow[t]{3}{*}{2} & 11 & 14002 & 11.6 & 11.1 & 0.5 & 67 & 255 \\
\hline & & 14014 & 11.6 & 11.1 & 0.5 & 68 & 255 \\
\hline & & 14007 & 11.6 & 11.1 & 0.5 & 69 & 255 \\
\hline \multirow[t]{3}{*}{2} & 19 & 14004 & 19.6 & 19.0 & 0.6 & 72 & 255 \\
\hline & & 14009 & 19.6 & 19.0 & 0.5 & 72 & 255 \\
\hline & & 14012 & 19.5 & 19.0 & 0.5 & 72 & 255 \\
\hline \multirow[t]{3}{*}{2} & 23 & 14002 & 22.8 & 23.0 & 0.2 & 72 & 255 \\
\hline & & 14007 & 22.8 & 23.0 & 0.2 & 67 & 239 \\
\hline & & 14023 & 23.0 & 23.0 & 0.1 & 72 & 255 \\
\hline \multirow[t]{3}{*}{2} & 34 & 14004 & 33.6 & 33.7 & 0.1 & 68 & 255 \\
\hline & & 14019 & 33.6 & 33.7 & 0.1 & 65 & 255 \\
\hline & & 14027 & 33.5 & 33.7 & 0.2 & 65 & 255 \\
\hline
\end{tabular}




\section{Post-Season Sensor Testing}

Six transmitters were reported to have questionable performance during the period when mobile tracking was conducted. Four of these tags were recovered and tested for sensor performance. All the tags noted as having questionable performance and all the tags recovered and tested during the postseason sensor testing were from the collection of tags purchased in 2014. These tags had been stored for 1 year following their manufacture, and in some cases had been used previously in fish. For example, tag ID 40039 had been used to tag a fish in 2014, had an unknown expenditure of battery life, and was recovered and stored until the start of the 2015 study.

One of the recovered tags had no remaining battery life at the time of testing, so it could not be evaluated. The long battery life ( $419 \mathrm{~d}$ ) for these tags, and the relatively short deployment period used for any tagged fish in 2015 (April-October, 215 d) suggests that this tag either had a premature battery failure, or was not deactivated during the fall and winter prior to the study.

The post-season test was an abbreviated version of the final test conducted during pre-season testing (experiment number 3 ), when tags were subjected to range of water temperatures. Tests were conducted at 0,19 , and $34^{\circ} \mathrm{C}$ to capture the low, medium, and high end of temperatures that might have been observed during the field study.

Tests were conducted in 19-L containers, with a temperature logger and an underwater antenna placed in the container along with the tag. Tags were placed in the container for 5 min to acclimate and then $5 \mathrm{~min}$ of data were collected on the telemetry receiver. The mean water temperature from the logger for every minute of the test was compared to the mean water temperature from the tag, and the difference between the two water temperatures (delta) was calculated. For each transmitter, we calculated the percentage of records that were out of compliance. Records were considered out of compliance if delta exceeded $0.85{ }^{\circ} \mathrm{C}$.

The tags accurately detected the low and medium water temperature, but were unreliable during the high water temperature test. During the $0{ }^{\circ} \mathrm{C}$ test, all three tags had 100 percent compliance: The mean delta for the test ranged from 0.29 to $0.410{ }^{\circ} \mathrm{C}$, and the maximum delta observed was $0.43{ }^{\circ} \mathrm{C}$ (table A4). During the $19{ }^{\circ} \mathrm{C}$ test, all three tags had 100 percent compliance: The mean delta for the test ranged from 0.02 to $0.83{ }^{\circ} \mathrm{C}$, and the maximum delta observed was $0.84{ }^{\circ} \mathrm{C}$. One tag (tag ID 40029) had temperature readings that were 100 percent in compliance, but was within $0.03{ }^{\circ} \mathrm{C}$ of being completely out of compliance. For this tag, the mean delta was $0.83{ }^{\circ} \mathrm{C}$, and the limit for delta was defined to be $0.85^{\circ} \mathrm{C}$. During the $34{ }^{\circ} \mathrm{C}$ test, all tags were substantially out of compliance. The mean delta for the test ranged from $0.65{ }^{\circ} \mathrm{C}$ to $1.16{ }^{\circ} \mathrm{C}$, and the maximum delta was $1.94{ }^{\circ} \mathrm{C}$ (table A4). The tag with the best performance at $34{ }^{\circ} \mathrm{C}$ was in compliance 63 percent of the time (table A4).

Overall, the findings of the post-season tag sensor testing provided evidence that the tags that were reported with questionable performance in the field were not functioning as specified by the manufacturer. All tags with questionable performance were from the 2014 tag order. These tags were manufactured in 2014 and were retained for use in this study. When tags are stored in the "off" position, with a magnet in place on the activation switch, there is still some quiescent battery drain. With a large expected tag life, radio tags used for adult salmon studies commonly are transferred from one study to another, as was done with this study. Of the 23 tags used for this study, 19 tags were from the 2014 tag order and 6 tags were reported to have questionable performance (32 percent). Only four of the 2015 tags were deployed for the study, and none were reported to have questionable performance. Although 
none of the tags used for the study appeared to have reached the end of their battery life during the study, one tag was dead at the time of the post-season testing, suggesting that it was near the end of the life of the battery while it was being monitored in the field. These findings, along with the poor performance of the tag temperature sensor, suggest that the sensor may become unreliable at some point prior to the end of the battery life. Under this circumstance, the tag would continue to emit a signal that could be used to detect the presence of the fish, but the sensor would not be reliable. Although the postseason testing suggests that the tags were within specifications at $0{ }^{\circ} \mathrm{C}$, and mostly in compliance at 19 ${ }^{\circ} \mathrm{C}$, the pre-season testing (when tags had more battery life) showed full compliance across the range of temperatures. The lack of compliance at any temperature, therefore, makes the sensor data questionable at all temperatures.

The results of the post-season sensor testing suggest that the temperature sensor in these transmitters may become unreliable after some part of the tag life is expended. Caution should be used when tags with extended shelf life ( $>1$ year) are used.

Table A4. Radio transmitter temperature sensor testing conducted for transmitters with questionable performance during the field study when radio-tagged spring Chinook salmon were monitored in the Chehalis River, southwestern Washington, 2015.

[The three tags (tag ID) tested were implanted in spring Chinook salmon during spring 2015 and monitored throughout the summer and early fall. During the monitoring period, the temperature reading generated by the temperature sensor in the tags was thought to be unreliable based on the known ambient river temperatures. The tags were recovered from fish and returned to the laboratory for controlled tests to test the reliability of the sensors. Tags were tested at three water temperatures (target test temperature) and 5 minutes of sensor data were collected. The mean sensor temperatures were compared to the mean logger temperatures in the tank and the mean temperature difference (delta) was calculated. When the temperature difference exceeded $0.85^{\circ} \mathrm{C}$, the record was considered out of compliance, and the overall compliance for the tag was reported as a percentage of the total number of records for each tag at each test temperature $(\mathrm{N})]$

\begin{tabular}{ccccccccc}
\hline \multirow{2}{*}{ Tag ID } & $\mathbf{N}$ & $\begin{array}{c}\text { Target } \\
\text { test }\end{array}$ & $\begin{array}{c}\text { Mean } \\
\text { logger }\end{array}$ & $\begin{array}{c}\text { Mean } \\
\text { sensor }\end{array}$ & $\begin{array}{c}\text { Sensor } \\
\text { range }\end{array}$ & Mean delta & $\begin{array}{c}\text { Maximum } \\
\text { delta }\end{array}$ & $\begin{array}{c}\text { Compliance } \\
\text { (percentage) }\end{array}$ \\
\hline 40029 & 54 & 0 & 0.11 & 0.04 & 0 & 0.29 & 0.35 & 100 \\
40037 & 57 & 0 & 0.11 & 0.04 & 0 & 0.29 & 0.35 & 100 \\
40039 & 55 & 0 & -0.01 & 0.04 & 0 & 0.41 & 0.43 & 100 \\
& & & & & & & & \\
40029 & 54 & 19 & 18.83 & 18.0 & 0 & 0.83 & 0.84 & 100 \\
40037 & 58 & 19 & 18.83 & 18.8 & 0 & 0.03 & 0.04 & 100 \\
40039 & 59 & 19 & 18.79 & 18.8 & 0 & 0.02 & 0.03 & 100 \\
& & & & & & & & \\
40029 & 60 & 34 & 33.53 & 32.4 & 0.8 & 1.16 & 1.94 & 0 \\
40037 & 60 & 34 & 33.56 & 32.9 & 0.8 & 0.65 & 1.07 & 63 \\
40039 & 55 & 34 & 33.56 & 32.6 & 0.8 & 0.92 & 1.24 & 29 \\
\hline
\end{tabular}




\section{Appendix B. Summary of Water Temperatures in the Chehalis River Basin during Summer 2015}

Table B1. Mean monthly water temperatures in the main-stem Chehalis River, southwestern Washington, summer 2015.

[Data are organized from downstream to upstream position. Location of each Site ID is shown in figure 1. NA indicates no data were available either because logger was not yet installed, stolen, or data did not pass the initial data screening process]

\begin{tabular}{ccccccccc}
\hline Site ID & River mile & March & April & May & June & July & August & September \\
\hline $30-\mathrm{CH}$ & 11.2 & NA & 11.7 & 15.2 & 19.7 & 21.3 & 20.7 & 18.4 \\
$26-\mathrm{CH}$ & 21.5 & NA & 12.0 & 15.8 & 17.4 & 20.5 & 18.6 & 17.9 \\
$31-\mathrm{CH}$ & 30.4 & NA & 13.8 & 16.1 & 21.0 & 22.8 & 21.8 & 18.6 \\
$24-\mathrm{CH}$ & 35.5 & 10.0 & 11.6 & 16.0 & 20.8 & 22.6 & 21.8 & 18.7 \\
$32-\mathrm{CH}$ & 40.7 & NA & 14.0 & 16.1 & 20.9 & 22.5 & 21.5 & 18.8 \\
$23-\mathrm{CH}$ & 44.3 & 9.9 & 11.7 & 16.2 & 21.0 & 22.6 & 22.0 & NA \\
$18-\mathrm{CH}$ & 53.4 & 11.9 & 11.6 & 16.2 & 21.0 & 22.6 & 21.4 & NA \\
$34-\mathrm{CH}$ & 56.7 & NA & NA & 16.3 & 19.8 & 21.2 & 20.8 & 19.0 \\
$17-\mathrm{CH}$ & 62.4 & NA & 12.4 & 16.0 & 21.5 & 23.4 & 21.9 & 19.2 \\
$33-\mathrm{CH}$ & 64.3 & NA & NA & 16.2 & 20.1 & NA & NA & NA \\
$35-\mathrm{CH}$ & 69.5 & NA & NA & 15.4 & 21.4 & 23.4 & 22.0 & 19.5 \\
$16-\mathrm{CH}$ & 70.2 & 9.4 & 10.7 & NA & 22.4 & 24.4 & 22.7 & 19.7 \\
$36-\mathrm{CH}$ & 74.7 & NA & NA & 16.2 & 21.9 & 24.0 & 22.5 & 18.5 \\
$37-\mathrm{CH}$ & 78.9 & NA & NA & 16.6 & 21.8 & 23.6 & 22.1 & 18.1 \\
$21-\mathrm{CH}$ & 83.6 & 9.4 & 10.9 & 16.0 & 21.7 & 23.6 & 22.1 & 17.8 \\
$20-\mathrm{CH}$ & 92.5 & 8.8 & 10.6 & 15.6 & 21.2 & 23.4 & 22.5 & NA \\
$19-\mathrm{CH}$ & 99.7 & NA & 9.9 & 14.5 & 20.0 & 22.4 & 21.0 & 16.6 \\
\hline
\end{tabular}


Table B2. Mean monthly water temperatures in the tributary subbasins of the Chehalis River, southwestern Washington, summer 2015.

[Data for each subbasin are organized from downstream to upstream position. Location of each Site ID is shown in figure 1. NA indicates no data available either because logger was not yet installed, stolen, or data did not pass the initial data screening process]

\begin{tabular}{llllllllc}
\hline \multicolumn{1}{c}{ Subbasin } & Site ID & March & April & May & June & July & August & September \\
\hline Black River & BLACK-1 & NA & NA & 16.1 & 19.1 & 20.6 & 19.5 & 16.9 \\
& BLACK-2 & NA & 11.5 & 15.0 & 19.4 & 21.3 & 20.2 & 17.6 \\
Skookumchuck & SKOOK-1 & NA & 11.2 & 13.4 & 17.8 & 19.7 & 19.4 & 16.2 \\
$\quad$ & & & & & & & \\
\multicolumn{1}{c}{ River } & SKOOK-2 & NA & 11.0 & 12.8 & 16.7 & 17.8 & 17.4 & 15.4 \\
& SKOOK-3 & NA & 10.0 & 11.5 & 14.5 & 14.7 & 15.5 & 14.4 \\
Newaukum River & NEW-1 & 9.2 & 10.7 & 15.2 & 20.6 & 22.8 & 21.4 & 17.8 \\
& NFNEW-2 & 8.7 & 10.0 & 13.9 & 18.9 & 21.5 & 20.3 & 16.5 \\
& NEW-7 & NA & 14.1 & 14.1 & 19.0 & 21.3 & 20.2 & 16.5 \\
& NFNEW-5 & 8.0 & 8.5 & 11.1 & 14.2 & 16.2 & 15.5 & 12.6 \\
South Fork Chehalis & NEW-8 & NA & 11.1 & 10.6 & 13.8 & 15.8 & 15.2 & 12.6 \\
River & SFCHEH-1 & NA & NA & 15.3 & 20.5 & 22.6 & 20.6 & 18.0 \\
& & & & & & & & \\
& SFCHEH-2 & NA & NA & 15.5 & 20.5 & 22.3 & 19.6 & 17.6 \\
& SFCHEH-3 & NA & NA & 14.7 & 19.4 & 21.3 & 19.7 & 16.3 \\
& STIL-1 & NA & NA & 12.7 & 16.0 & 18.0 & 17.2 & NA \\
Upper Chehalis & SFCHEH-4 & NA & NA & 13.2 & 17.7 & 19.9 & 18.9 & 14.9 \\
River & 4-UCH & 8.6 & 9.7 & 14.4 & 18.0 & 21.4 & 20.7 & 16.8 \\
& & & & & & & & \\
& 3-UCH & 8.3 & 9.2 & 13.3 & 17.9 & 20.3 & 19.2 & 15.6 \\
& 2-UCH & 8.1 & 9.2 & 13.4 & 18.0 & 20.2 & 19.0 & 15.2 \\
\hline
\end{tabular}


Table B3. Minimum monthly water temperatures in the main-stem Chehalis River, southwestern Washington, summer 2015.

[Data are organized from downstream to upstream position. Location of each Site ID is shown in figure 1. NA indicates no data were available either because logger was not yet installed, stolen, or data did not pass the initial data screening process]

\begin{tabular}{rcccccccc}
\hline Site & River mile & March & April & May & June & July & August & September \\
\hline $30-\mathrm{CH}$ & 11.2 & NA & 11.3 & 14.7 & 19.1 & 20.7 & 20.1 & 17.7 \\
$26-\mathrm{CH}$ & 21.5 & NA & 11.4 & 15.2 & 17.0 & 19.5 & 17.4 & 17.6 \\
$31-\mathrm{CH}$ & 30.4 & NA & 13.1 & 15.4 & 20.1 & 21.8 & 20.6 & 18.2 \\
$24-\mathrm{CH}$ & 35.5 & 9.5 & 11.0 & 15.2 & 19.7 & 21.4 & 20.5 & 18.6 \\
$32-\mathrm{CH}$ & 40.7 & NA & 13.3 & 15.4 & 19.7 & 21.5 & 20.6 & 18.4 \\
$23-\mathrm{CH}$ & 44.3 & 9.4 & 10.9 & 15.4 & 19.9 & 21.2 & 20.8 & NA \\
$18-\mathrm{CH}$ & 53.4 & 11.4 & 10.7 & 15.2 & 19.5 & 21.1 & 19.9 & NA \\
$34-\mathrm{CH}$ & 56.7 & NA & NA & 15.4 & 18.5 & 19.8 & 19.6 & 18.8 \\
$17-\mathrm{CH}$ & 62.4 & NA & 11.7 & 15.0 & 20.2 & 22.2 & 21.1 & 19.0 \\
$33-\mathrm{CH}$ & 64.3 & NA & NA & 15.3 & 18.8 & NA & NA & NA \\
$35-\mathrm{CH}$ & 69.5 & NA & NA & 14.7 & 20.7 & 22.6 & 21.2 & 19.1 \\
$16-\mathrm{CH}$ & 70.2 & 9.2 & 10.5 & NA & 21.7 & 23.6 & 22.1 & 19.4 \\
$36-\mathrm{CH}$ & 74.7 & NA & NA & 15.7 & 21.0 & 23.3 & 21.8 & 18.2 \\
$37-\mathrm{CH}$ & 78.9 & NA & NA & 15.9 & 20.8 & 22.8 & 21.4 & 17.8 \\
$21-\mathrm{CH}$ & 83.6 & 8.8 & 10.0 & 14.9 & 19.9 & 22.0 & 20.5 & 17.4 \\
$20-\mathrm{CH}$ & 92.5 & 7.6 & 9.6 & 14.4 & 19.4 & 21.6 & 20.9 & NA \\
$19-\mathrm{CH}$ & 99.7 & NA & 8.8 & 13.3 & 18.2 & 20.3 & 18.9 & 16.2 \\
\hline
\end{tabular}


Table B4. Minimum monthly water temperatures in the tributary subbasins of the Chehalis River, southwestern Washington, summer 2015.

[Data for each subbasin are organized from downstream to upstream position. Location of each Site ID is shown in figure 1. NA indicates no data were available either because logger was not yet installed, stolen, or data did not pass the initial data screening process]

\begin{tabular}{llllllllc}
\hline \multicolumn{1}{c}{ Subbasin } & Site ID & March & April & May & June & July & August & September \\
\hline Black River & BLACK-1 & NA & NA & 15.5 & 18.1 & 19.1 & 18.0 & 16.7 \\
& BLACK-2 & NA & 10.8 & 13.9 & 17.9 & 20.1 & 19.0 & 17.4 \\
Skookumchuck & SKOOK-1 & NA & 10.4 & 12.7 & 16.6 & 18.5 & 18.2 & 15.7 \\
$\quad$ & & & & & & & \\
River & SKOOK-2 & NA & 9.5 & 11.4 & 15.3 & 16.5 & 16.0 & 14.8 \\
& SKOOK-3 & NA & 9.1 & 10.5 & 12.9 & 13.3 & 14.0 & 13.9 \\
Newaukum River & NEW-1 & 8.5 & 9.7 & 13.9 & 18.9 & 20.9 & 19.5 & 17.0 \\
& NFNEW-2 & 7.8 & 8.7 & 12.8 & 17.2 & 19.8 & 19.1 & 15.8 \\
& NEW-7 & NA & 11.7 & 12.5 & 16.7 & 19.2 & 18.1 & 15.6 \\
& NFNEW-5 & 6.8 & 6.9 & 9.6 & 12.2 & 14.4 & 14.0 & 11.9 \\
& NEW-8 & NA & 10.1 & 9.3 & 12.0 & 14.1 & 13.8 & 11.9 \\
South Fork Chehalis & SFCHEH-1 & NA & NA & 13.8 & 18.9 & 20.9 & 19.7 & 17.0 \\
River & & & & & & & & \\
& SFCHEH-2 & NA & NA & 14.2 & 18.7 & 20.6 & 18.8 & 16.4 \\
& SFCHEH-3 & NA & NA & 13.6 & 17.8 & 19.5 & 18.0 & 15.3 \\
& STIL-1 & NA & NA & 11.0 & 13.5 & 15.6 & 15.1 & NA \\
& SFCHEH-4 & NA & NA & 11.4 & 15.0 & 17.2 & 16.6 & 13.3 \\
Upper Chehalis & 4-UCH & 7.5 & 8.1 & 12.5 & 15.4 & 19.1 & 18.2 & 15.0 \\
River & & & & & & & & \\
& 3-UCH & 7.2 & 7.6 & 11.7 & 16.0 & 19.0 & 17.8 & 14.5 \\
& 2-UCH & 7.2 & 7.6 & 11.6 & 15.1 & 17.2 & 16.3 & 14.3 \\
& 7-UCH & 6.9 & 7.2 & 10.9 & 14.6 & 17.0 & 16.7 & NA \\
\hline
\end{tabular}


Table B5. Maximum monthly water temperatures in the main-stem Chehalis River, southwestern Washington, summer 2015.

[Data are organized from downstream to upstream position. Location of each Site ID is shown in figure 1. NA indicates no data were available either because logger was not yet installed, stolen, or data did not pass the initial data screening process]

\begin{tabular}{rcccccccc}
\hline Site & River mile & March & April & May & June & July & August & September \\
\hline $30-\mathrm{CH}$ & 11.2 & NA & 12.2 & 15.6 & 20.3 & 21.9 & 21.2 & 18.9 \\
$26-\mathrm{CH}$ & 21.5 & NA & 12.6 & 16.6 & 18.1 & 21.7 & 20.2 & 18.0 \\
$31-\mathrm{CH}$ & 30.4 & NA & 14.3 & 16.8 & 21.9 & 23.9 & 23.2 & 19.0 \\
$24-\mathrm{CH}$ & 35.5 & 10.4 & 12.3 & 16.9 & 22.0 & 24.2 & 23.1 & 18.9 \\
$32-\mathrm{CH}$ & 40.7 & NA & 14.5 & 17.0 & 22.2 & 23.5 & 22.3 & 19.3 \\
$23-\mathrm{CH}$ & 44.3 & 10.4 & 12.4 & 17.0 & 22.4 & 24.2 & 23.3 & NA \\
$18-\mathrm{CH}$ & 53.4 & 12.5 & 12.5 & 17.2 & 22.9 & 24.3 & 23.2 & NA \\
$34-\mathrm{CH}$ & 56.7 & NA & NA & 17.4 & 21.3 & 22.6 & 22.2 & 19.4 \\
$17-\mathrm{CH}$ & 62.4 & NA & 13.3 & 17.1 & 22.8 & 24.9 & 22.9 & 19.5 \\
$33-\mathrm{CH}$ & 64.3 & NA & NA & 17.4 & 21.5 & NA & NA & NA \\
$35-\mathrm{CH}$ & 69.5 & NA & NA & 16.2 & 22.1 & 24.2 & 22.9 & 20.0 \\
$16-\mathrm{CH}$ & 70.2 & 9.6 & 10.9 & NA & 23.4 & 25.2 & 23.4 & 19.9 \\
$36-\mathrm{CH}$ & 74.7 & NA & NA & 16.7 & 22.7 & 24.9 & 23.5 & 18.9 \\
$37-\mathrm{CH}$ & 78.9 & NA & NA & 17.5 & 22.8 & 24.5 & 23.1 & 18.3 \\
$21-\mathrm{CH}$ & 83.6 & 10.0 & 11.8 & 17.3 & 23.3 & 25.3 & 23.7 & 18.2 \\
$20-\mathrm{CH}$ & 92.5 & 10.1 & 11.7 & 17.2 & 23.4 & 25.9 & 24.7 & NA \\
$19-\mathrm{CH}$ & 99.7 & NA & 11.2 & 15.8 & 22.1 & 24.8 & 22.9 & 17.0 \\
\hline
\end{tabular}


Table B6. Maximum monthly water temperatures in the tributary subbasins of the Chehalis River, southwestern Washington, summer 2015.

[Data for each subbasin are organized from downstream to upstream position. Location of each Site ID is shown in figure 1. NA indicates no data were available either because logger was not yet installed, stolen, or data did not pass the initial data screening process]

\begin{tabular}{llllllllc}
\hline \multicolumn{1}{c}{ Subbasin } & Site ID & March & April & May & June & July & August & September \\
\hline Black River & BLACK-1 & NA & NA & 16.9 & 20.5 & 22.4 & 20.9 & 17.2 \\
Skookumchuck & BLACK-2 & NA & 12.5 & 16.3 & 20.8 & 22.6 & 21.6 & 17.8 \\
$\quad$ River & SKOOK-1 & NA & 12.0 & 14.2 & 19.1 & 21.0 & 20.4 & 16.9 \\
& & & & & & & & \\
\multirow{5}{*}{ Newaukum River } & SKOOK-2 & NA & 12.4 & 14.0 & 18.0 & 19.2 & 19.0 & 16.2 \\
& SKOOK-3 & NA & 11.2 & 12.9 & 16.6 & 16.5 & 17.0 & 15.2 \\
& NEW-1 & 10.0 & 11.7 & 16.5 & 22.5 & 25.2 & 23.7 & 18.8 \\
& NFNEW-2 & 9.7 & 11.3 & 15.0 & 20.6 & 23.0 & 21.7 & 17.3 \\
& NEW-7 & NA & 15.1 & 15.8 & 21.5 & 24.0 & 22.6 & 17.7 \\
& NFNEW-5 & 9.1 & 10.2 & 13.0 & 16.3 & 18.0 & 17.1 & 13.4 \\
South Fork & NEW-8 & NA & 11.7 & 12.1 & 15.6 & 17.6 & 16.6 & 13.4 \\
Chehalis River & SFCHEH-1 & NA & NA & 16.8 & 22.2 & 24.4 & 21.4 & 19.0 \\
& & & & & & & & \\
& SFCHEH-2 & NA & NA & 16.9 & 22.7 & 24.4 & 20.4 & 18.9 \\
& SFCHEH-3 & NA & NA & 15.9 & 21.2 & 23.1 & 21.6 & 17.4 \\
& STIL-1 & NA & NA & 15.0 & 19.1 & 20.8 & 19.9 & NA \\
Upper Chehalis & SFCHEH-4 & NA & NA & 15.5 & 20.9 & 22.8 & 21.7 & 16.6 \\
River & 4-UCH & 9.9 & 11.5 & 16.8 & 21.1 & 24.2 & 23.3 & 18.7 \\
& & & & & & & & \\
& 3-UCH & 9.6 & 11.0 & 15.2 & 19.6 & 22.1 & 21.6 & 16.6 \\
& 2-UCH & 9.2 & 10.8 & 15.6 & 21.6 & 24.0 & 22.2 & 16.7 \\
\hline
\end{tabular}


Publishing support provided by the U.S. Geological Survey

Science Publishing Network, Tacoma Publishing Service Center

For more information concerning the research in this report, contact the Director, Western Fisheries Research Center U.S. Geological Survey

6505 NE 65th Street

Seattle, Washington 98115

http://wfrc.usgs.gov/ 
